\title{
ADUBAÇÃO NITROGENADA E POTASSICA NA CONCENTRAÇÃO DE ÁCIDO OXÁLICO EM CAPIM SETÁRIA (detaria ancops STAPF) CV. KAZUNGULA EM UM SOLO ORTHIC QUARTZIPSAMMENT
}

\author{
OSCAR ANTONIO MOLAS BUSCIO
}

Orientador: Prof. Dr. CLAUDIO MALUF HADDAD

Dissertação apresentada à Escola Superior de Agricultura "Luiz de Queiroz", da Universidade de São Paulo, para obtenção do título de Mestre em Agronomia. Área de Concentração: Nutrição Animal e Pastagens.

$P$ I R A I C A B A

Estado de São Paulo - Brasil

Abril - 1986 
Aos meus pais,

ANGELA E JULIAN,

pelos seus ensinamentos,

exemplos de amor e trabalho,

MINHA GRATIDÃO.

A minha esposa DORA,

pelo estímulo, dedicação e anor,

e a meus filhos, ROSANNA, OSCAR

e ROORIGO, companheiros desta jornada,

MINHA DEDICAÇAOO. 


\section{A GRADE.C I MENT.OS}

Ao Prof. Dr. Claudio Maluf Haddad, pela amizade e orientação durante o Curso de..Pōs-Graduação e execução deste trabalho.

Aos Docentes do Departamento de Zootecnia da ESALQ/USP, pe los ensinamentos recebidos.

A Prof? Dr? Marinēia de Lara Haddad pelo auxílio na interpretação da anālise estatística e oportunas sugestöes.

A Escola Superior de Agricultura "Luiz de Queiroz", da Universidade de São Paulo, Piracicaba - S.P., pela opor tunidade de aperfeiçoamento.

Ao Ministério de Agricultura y Ganaderia (M.A.G.), do Para guay, dẹvo agradecimento por me ter permitido frequen tar o Curso de Pōs-Graduação e pela concessão da bolsa de estudo.

Ao. Programa Nacional de Investigaciōn y Extensiōn Ganadera (PRONIEGA) pela permissão outorgada.

Aos funcionärios do laboratōrio de Zootecnia, Química, CENA pelo auxílio nos trabalhos de laboratório.

A Limeirense de Fertilizantes pela ajuda outorgada.

Aos colegas do Curso de Pōs-Graduação, pelo incentivo. 
I N D I C E

Pāgina

RESUMO $\ldots \ldots \ldots \ldots \ldots \ldots \ldots \ldots \ldots \ldots \ldots \ldots \ldots \ldots \ldots \ldots \ldots \ldots$

SUMMARY $\ldots \ldots \ldots \ldots \ldots \ldots \ldots \ldots \ldots \ldots \ldots \ldots \ldots \ldots \ldots \ldots \ldots \ldots \ldots$

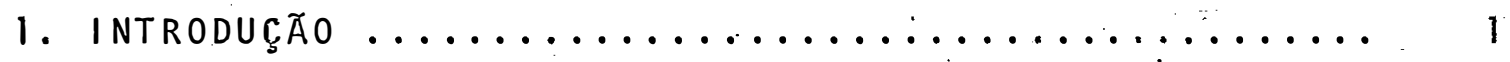

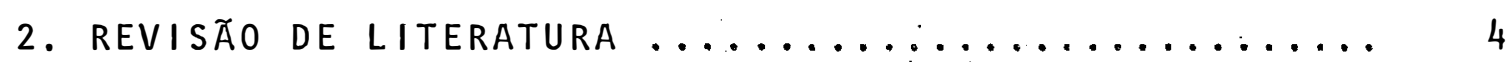

2.1. Origem e Distribuição Geogräfica ........... 4

2.2. Descrição da Espécie ................ 5

2.3. Cultivares ...................... 6

2.3.1. Nandi ...................... 6

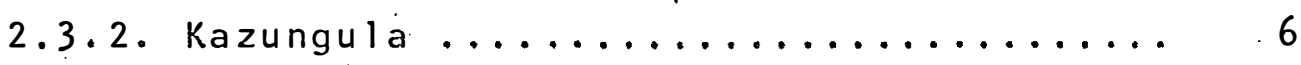

2.3.3. Narok $\ldots \ldots \ldots \ldots \ldots \ldots \ldots \ldots \ldots \ldots \ldots$

2.4. Exigências Climăticas e Edäficas ........... 7

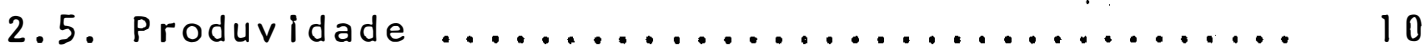

2.6. Respostas a Fertilizantes ............. 12

2.7. Valor Nutritivo $\ldots \ldots \ldots \ldots \ldots \ldots \ldots \ldots \ldots \ldots$

2.8. Problemas Relacionados com Setaria anceps … 20

3. MATERIAL E METOdOS ................... 40

3.1. Material ........................ 40

3.1 .1 . Local .................... 40

3.1.2. Solo e Espécie Vegetal ........... 40 
Pāọ ina

3.1.3. Material Corretivo .............. 47

3.1.4. Fonte de Nutrientes .............. 42

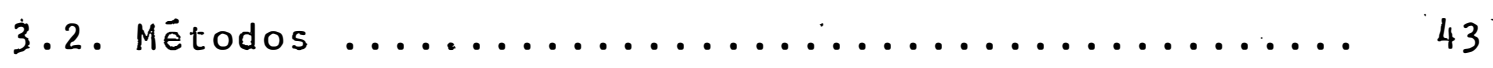

4. RESULTADOS E DISCUSSÃO .................... 50

4.1. Efeito de Doses de Nitrogênio e Potássio na produção de Matēria Seca ................... 50

4.2. Efeito dos Tratamentos sobre a Concentração de

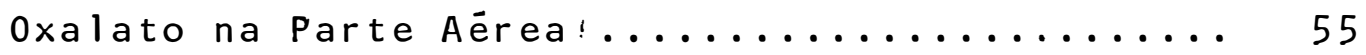

4.3. Efeito dos Tratamentos sobre a Concentração de Nitrogênio, Potássio, Cälcio e Magnēsio........ 58

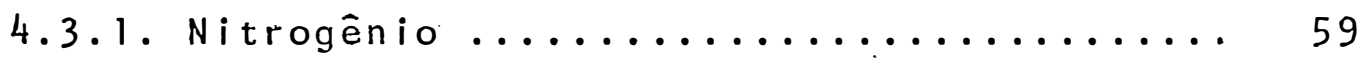

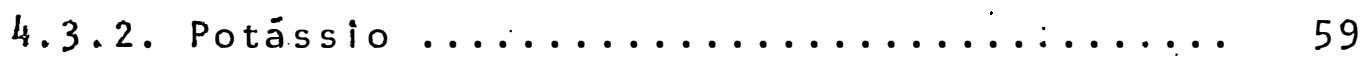

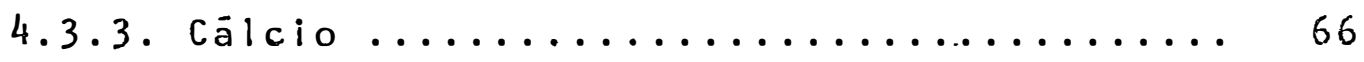

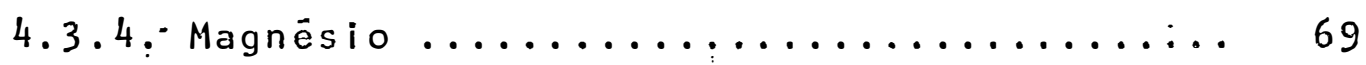

4.4. Efeito dos Tratamentos sobre os Teores de cálcio e Oxalato e a Relação Cālcio/0xalato na Matéría

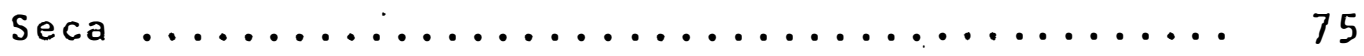

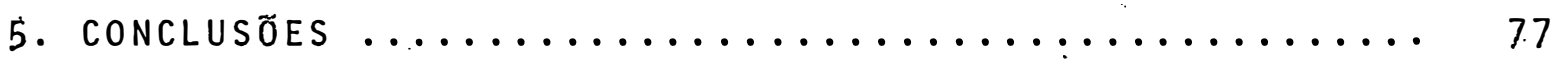

6. LITERATURA CITADA .......................... 79

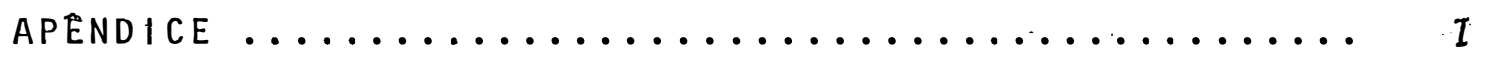




\section{LISTA DE TABELAS}

Pägina

Tabela 1 - Produtividade do capim setaria ..........

Tabela 2. - Produção anual de matéria seca e de proteína bruta de Setaria anceps c.v. Naridi e Kazungula com adubação nitrogenada ........

Tabela 3 - Produção de feno de Setaria anceps c.v. Kazungula em função de adubação fosfatada e nitrogenada $\ldots \ldots \ldots \ldots \ldots \ldots \ldots$

Tabela 4 - Composição química da matēría seca de Setaria anceps $(\%) \ldots \ldots \ldots \ldots \ldots \ldots \ldots \ldots \ldots \ldots \ldots \ldots \ldots \ldots \ldots$

Tabela 5 - Digestibilidade e composição química da matēria seca (M.S.) de pastagens de pangola (Digitaria decumbens), capim Rhodes (Chloris gayana) e setaria (setaria anceps)........

Tabela 6 - Conteūdo de matéria seca, proteína bruta e coeficiente de digestibilidade aparente da matéria seca, e energia total e proteína bru ta da Setaria anceps em diferentes idades de rebrota e maturidade.................

Tabela 7 - Média de oxalato total e solúvel em āgua e conteūdo de Cälcio (Ca) e Nitrogênio (N).... 
Tabela 8 - 0 efeito da fertilização com urēia sobre o oxalato e a composição mineral do $\underline{S}$. anceps.

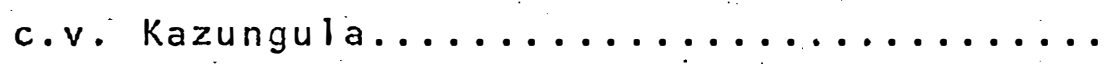

Tabela 9 - 0 efeito da fertilização nitrogenada e a idade de rebrota da $\underline{S}$. sphacelata em outono e primavera sobre o oxalato solüvel, nitrogềnio, potässio e sódio no material vegetal

Tabela 10- Efeito da fertilização nitrogenada e potássica sobre o conteúdo de oxalato de Setaria

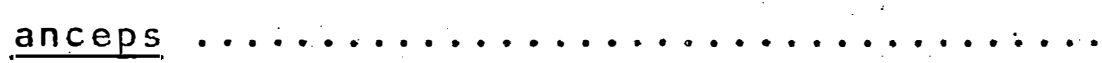

Tabela 11- Efeito do incremento dos niveis de $N$ sobre a concentração de oxalato nas partes das

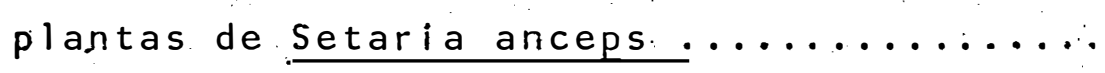

Tabela 12- Efeito do intervalo de corte sobre a porcen tagem de ácido oxálico em Setaria anceps.

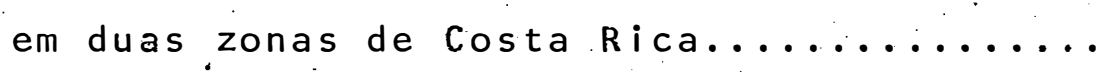

Tabela 13-Níveis de Cālcio (Ca) no plasma sanguíneo de oito vacas lactantes sadias e oito doen-

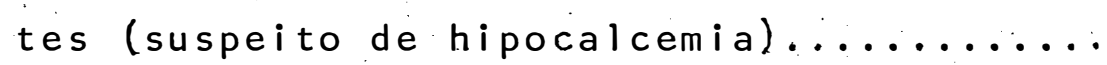

Tabela 14- Anālise bioquímicas de diversas espécies de gramíneas. Dados médios, na base da matéria

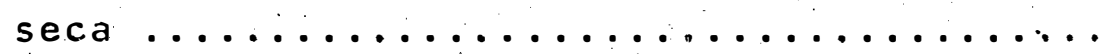


Tabela 15 - Principais características químicas de amos-

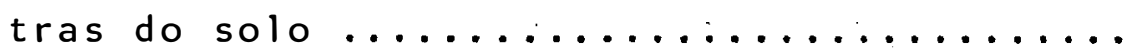

Tabela 16 - Principais caracteristicas físico-químicas

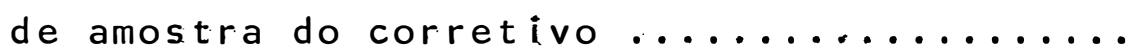

Tabela 17 - Esquema dos tratamentos utilizados no experí

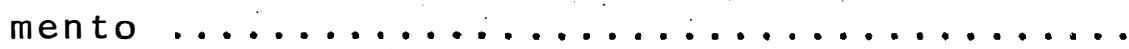

Tabela 18 - Doses e soluções dé macro e micronutrientes

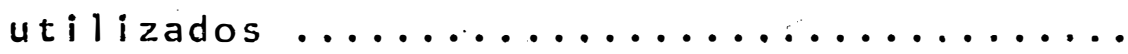

Tabela 19 - Esquema de análises de variância...........

Tabela 20 - Médias gerais da produção de matéria seca a $70^{\circ} \mathrm{C}$, da parte aērea das plantas (g/vaso) em função dos níveis de $N$ e K e o quadro da anā

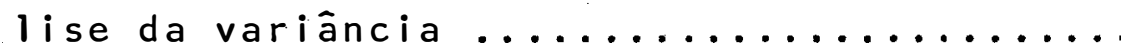

Tabela 21 - Mëdias geraís da concentração de ācido oxáli co, em \%, na parte aérea das plantas em função dos níveís de $N$ e $K$ e o quadro de análise de variância (Média de 4 repetições)......

Tabela 22 - Médias gerais da concentração de Nitrogênio, em \%, na parte aérea das plantas, em função dos níveis de $N$ e K e o quadro de anälise de variância (Média de 4 repetições)........... 
Tabela 23 - Médias gerais da concentração de Potāssio, em \%, na parte aérea das plantas, em função dos níveis de $N$ e $K$ e o quadro de anälise de variância (Média de 4 . repetições).

Tabela 24 - Médias geraís da concentração de Cálcio, em $\%$, na parte aērea das plantas, em função dos níveis de $N$ e $K$ e o quadró de anālise de variância (Mëdià de 4. repetições).

Tabela 25 - Médias gerais da concentração de Magnésio, em $\%$, na parte aérea das plantas, em função dos níveis de $N$ e K e o quadro de análise de variância (Média de 4 repetições). 71

Tabela 26 - Médias gerais da relação cálcio:oxalato em \% na matéria seca da parțe aérea do capim setaria (Média de 4 repetições)...... 76 


\section{Lista de Tabelas do ApÉndice}

Pāgina

Tabela 1 - Produção de matéria seca a $70^{\circ} \mathrm{C}$ da parte aérea do capim setaria (g/vaso) em função dos

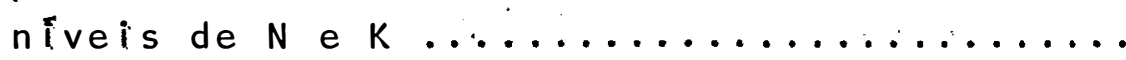

Tabela 2 - Concentração de Âcido 0xālico em \% na maté ria seca $\left(70^{\circ} \mathrm{C}\right)$ da parte aéré do capim setaria ém função dos níveis de $N$ e $K \ldots . . . .$.

Tabela 3 - Concentração de Nitrogênio em \% na matēria seca da parte aérea do capim setaria em fun-

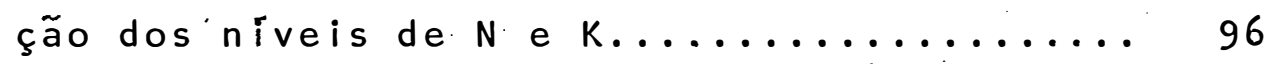

Tabela 4 - Concentração de Potāssio em \% na matéria seca da parte aérea do capim setaria em fun-

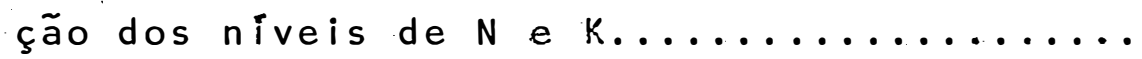

Tabela 5 - Concentração de Cálcio em \% na matéria seca da parte aérea do capim setaria em função

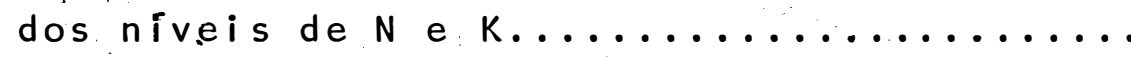

Tabela 6 - Concentração de Magnésio na matéria seca da parte aérea do capim setaria em função dos

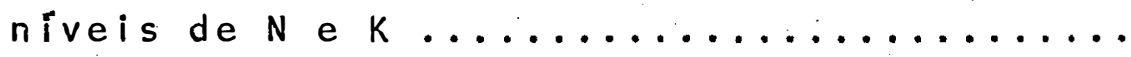




\section{LISTA DE FIgURAS}

Pàgina

Figura 1 - Variação diurna do conteūdo de oxalato em Setaria anceps, c.v. Kazungula e Nandi expres so como anidro de ácido oxálico na matéria

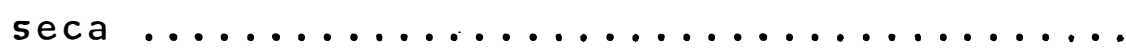

Figura 2 - Regressão linear do'total de oxalato em folha e caule de Setaria splendida colhida há 3 semanas em relação à concentração de nitro gềnio $\ldots \ldots \ldots \ldots \ldots \ldots \ldots \ldots \ldots \ldots \ldots \ldots \ldots \ldots \ldots \ldots \ldots \ldots \ldots \ldots$

Figura 3 - Regressão linear do total de oxalato em folha, e caule de Setaria splendida, colhida há 3 semanas em relação a \% de folha......... 34

Figura 4 - Regressão linear do total de oxalato em folha e caule de Setaria splendida colhida há 3 semanas em relação a taxa de crescimento.. 35

Figura 5 - Eféito da dose de K na produção de matēria seca (g/vaso) da parte aéreà do capim setá -

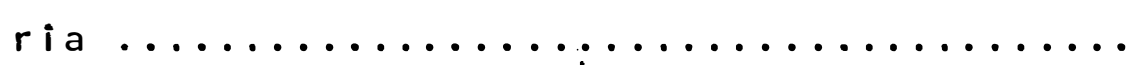

Figura 6 - Efeito de doses de K. na. produção. de matëría seca (g/vaso) da parte aérea do capim setaria $: a .: \ldots \ldots \ldots \ldots \ldots \ldots \ldots \ldots$ 
Página

Figura 7 - Efeito de doses de. K na concentração de ácido oxálico (\%) da parte aérea do capim se-

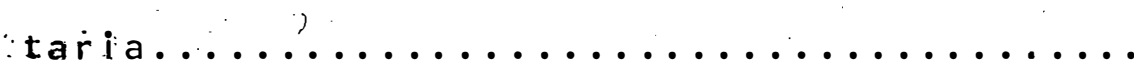

Figura 8 - Efeito de doses de $\mathbf{N}$ na concentração de $\mathbf{N i -}$ trogênio. (\%) da parte aērea do capim setaria

Figura 9 - Efeito de doses de $N$ na concentração de potássio (\%) da parte aérea do capim setaria..

Figura 10- Efeito de doses de potássio na concentração de potássio (\%) da parte aérea do capim se-

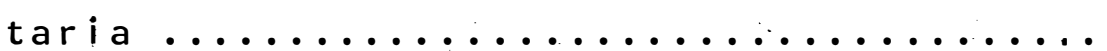

Figura 11- Efeito de doses de $N$ na concentração de cālci.o (\%) da parte aérea do capim setaria....

Figura 12- Efeito de doses de $K$ na concentração de cálcio (\%) da parte aérea do capim setaria....

Figura 13-Efeito de doses de $\mathrm{N}$ na concentração de magnësio (\%) na parte aërea do capim setaria...

Figura 14-Efeito de dosels de $K$ na concentração de magnésio (\%) na parte aérea do capim setaria... 74 


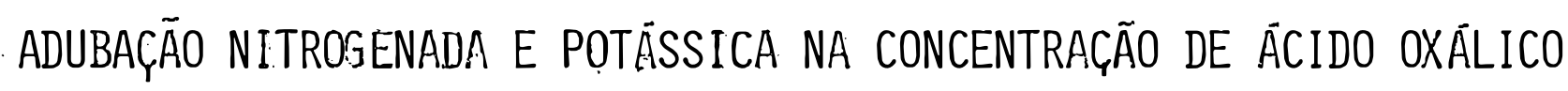
EM CAPIM SETARIA (setaria anceps STAPF) CV, KAZUNGULA

EM UMI SOLO ORTHIC QUARTZIPSAMMENT

autor: Oscar Antonio Molas Buscio orientador: Prof, Dr. Claudio Maluf Haddad

\begin{abstract}
RESUMO
o presente trábalho teve como objetivo verificar o efeito de doses crescentes de nitrogênio na forma de urēia $\left(N_{0}=0 ; N_{1}=50 ; N_{2}=100 ; N_{3}=150 \approx N_{4}=200 \mathrm{~kg} \mathrm{~N} /\right.$ ha) e potássio na forma de cloreto de potássio $\left(K_{0}=0 ; K_{1}=\right.$ $100 \mathrm{e} \mathrm{K}_{2}=200 \mathrm{~kg} \mathrm{~K} / \mathrm{hal}$ ) sobre a concentração do ácido oxálico na matéria seca do capim setaria (Setaria anceps. c.v. Kazungu la), num esquema fatorial $5 \times 3$ inteiramente casualizado, com 4 repetições. O trabalho experimental foi desenvolvido em casa de vegetação do Departamento de Agricultura e Horticultura da Escola Superior de Agricultura "Luiz de Queiroz", utilizan do vasos de solo classificado como Série Ribeirão Claro. Os seguintes parâmetros foram determinados trinta e cinco dias apōs a semeadura: a) rendimento da matéria sećca da parte aérea: b) concentração de oxalato na parte aérea da gramínea em estudo; c) teor de nitrogênio, potássio, cálcio e magnésio na matéria seca e d) relação de călcio/oxalato. os resultados obtidos revelaram: 1) houve um efeito quadrático
\end{abstract}


do $N\left(Y=1,7752+0,05319 x-0,00011 x^{2}\right)$ e linear do $K$ $(Y=4,35+0,0098 x)$ sobre a produção de MS do capim setária; 2) o efeito do K sobre o teor de oxalato na matéria se ca foi linear $(Y=4,5150+0,0047 x)$; o máximo teor de oxalato $(5,45 \%)$ foi alcançado com nível $\left.\mathrm{K}_{2}(200 \mathrm{~kg} \mathrm{~K} / \mathrm{ha}) ; 3\right)$ os teores mínimo e mäximo de $N(0,69 \%$ a $2,53 \%), K(0,58 \%$ a $3,70 \%), \operatorname{Ca}(0,32 \%$ a $0,41 \%)$ e $\operatorname{Mg}(0,29 \%$ a $0,47 \%)$ em função dos níveis de $\mathrm{N}$ e $K$, encontram-se acima dos valores conside rados críticos para a nutrição bovina; e) a relação cálciol oxalato em função: dos tratamentos, apresentam valores cons derados nocivos para a saūde animal $(0,063 \%$ a $0,086 \%)$. Dos resultados obtidos permite-se concluir o seguinte:

- uma māxima produção de matēria seca é possível mediante o efeito associativo da fertilização ni trogenada versus potāsíica;

- o potássio influi diretamente sobre o conteúdo de oxalato na matēria seca;

- o efeito do nitrogênio e indireto sobre a concentração de oxalato;

- os teores de $N, K, C a$ e Mg da gramínea colhida aos 35 dias são suficientes para atender às exigências nutritivas do gado de corte;

- a relação cālcio/magnēsio apresentam valores muito abaixo da exigência requerida para a nutrição animal. 
NITROGEN AND POTASSIUM FERTILIZATION ON OXALATE CONCENTRATION

IN SETARIA (Setaria anceps STAPF) CV, KAZUNGULA

IN A ORTHIC QUARTZIPSAMMENT SOIL

author: Oscar Antonio Molas Buscio adviser: Prof, Dr. Claudio Maluf Haddad

\section{SUMMARY}

This experiment was carried out in greenhouse at the Departamento de Agricultura e Horticultura, Escola Supe rior de Agricultura "Luiz de Queiroz", Piracicaba", Brazil, between March and July of 1985 .

Five levels of nitrogen (urea) $\left(N_{0}=0 ; N_{1}=\right.$ $50 \mathrm{~kg} \mathrm{~N} / \mathrm{ha} ; N_{2}=1.00 \mathrm{~kg} \mathrm{~N} / \mathrm{ha} ; N_{3}=150 \mathrm{~kg} \mathrm{~N} / \mathrm{ha} ; N_{4}=200 \mathrm{~kg}$ $\mathrm{N} /$ ha and three levels of potassium $(K C l)\left(K_{0}=0 ; K_{1}=100\right.$ and $\mathrm{K}_{2}=200 \mathrm{~kg} \mathrm{~K} / \mathrm{hal}$ were used in a $5 \times 3$ factorial design with four replicates in order to measure the levels of oxalic acid in Setaria anceps cr. Kazungula.

The plants were clipped at 35 days of growth and the following parameters were measured: a) serial part dry matter production; bL oxalate concentration; c) nitrogen, potassium, calcium and magnesium concentrations; and d) calcium/ oxalate ratio. 
There was a quadratic effect of $N$ $\left(Y=1.7752+0.05319 x-0.00011 x^{2}\right)$ and a 1 inear effect of $k$. $(y=4.35+0.0098 x)$ on the dry matter production. There was a linear effect of $k$ on the oxalate concentration $(Y=4.5150+0.0047 x) ;$ its maximum concentration $(5.45 \%)$ was reached at the highest $K$ level $(200 \mathrm{~kg} \cdot \mathrm{K} / \mathrm{ha})$. The lowest and the highest concentrations of $\mathrm{N}(0.69 \%$ to $2.33 \%)$, K $(0.58 \%$ to $3.70 \%), \mathrm{Ca}(0.32 \%$ to $0.41 \%)$ and $\mathrm{Mg}(0.29 \%$ to $0.47 \%$ ), were positively correlated with the $N$ and $K$ fertilizations levels and they are higher than the NRC requeriments for adult beef cattle in maintenance. The calcium/oxalate ratio was considered critical to animal health, specially for equines. The result of this experiment may lead one conclude that:

- a maximum dry matter production is obtained by the association of $N$ and $K$ fertilization;

- the potassium fertilization directly affects the oxalate level in. setaria;

- the nitrogen effect on the oxalate level is considered an indirect effect, through the action of the potassium level;

- the levels of $\mathrm{N}, \mathrm{K}, \mathrm{Ca}$ and $\mathrm{Mg}$ found were considered adequate for adult beef cattle in maintenance. 


\section{INTRODUÇÃO}

A produção de gado de corte em pastagens e uma das atividades de obtenção de alimentos mais importantes nas baixas latitudes da América Latina Tropical. Estas carac teristicas aplicam-se, particularmente, ao Brasil, que possui cerca de $60 \%$ do rebanho bovino localizado em áreas de cerrado. Os animais dependem, para. sua alimentação, de espēcies de gramíneas nativas ou de algumas outras espécies forrageiras, voluntäria ou acidentalmente introduzida de outras regiões, cuja capacidade de suporte dessas. pastagens é extremamente baixa e seu valor nutritivo muito variável com as estações do ano, atingindo valores realmente criticos durante a estação seca (PEDREIRA, 1973).

Uma das alternativas para suprir essas def $\underline{\mathbf{I}}$ ciências é a procura de novas gramíneas consideradas promissoras, sendo suas introduções feitas na maioria das vezes, sem um conhecimento mesmo rudimentar a respeito, e que tem 
levado a resultados negativos, motivado principalmente pelas limitações de clima e fertilidade do solo. Apesar destes fatos algumas gramíneas introduzidas. recentemente, como os capins andropogon (Andropogon gayanus c.v. Planaltina) e setäria (Setaria anceps) têm demonstrado ser bastante promissoras.

A Setaria anceps conhecida também como capim marangä ou capim do congo, tem despértado interesse dos pecuaristas, pelo bom comportamento em pastejo, boa capacidade de suporte e, espécialmente, pelo razoável potencial de cres cimento durante o período seco.

Pesquisas recentes, realizadas em värios pa! ses, mostraram que algumas cultivares desta espēcie contëm elevados teores de oxalato em seus tecidos (JONES e FORD, 1972a, ROUGHAN e SLACK, 1973; GONZÁLEZ e COWARD, 1977), os quais foram atribuídos casos de intoxicação em bovinos mant i dos em pastejo (SEAWRIGHT et alii, 1970; GONZALEZ e COWARD, 1977). Nesta espécie, as formas de oxalato predominantemente encontradas são o àcido oxálico ou oxalatos, de potássio, södio e cálcio (JONES e FORD, 1972b).

Desde que seja possível que a produtivida de da pastagem de Setaria anceps possa ser influenciada pèlos elementos enumerados acima, um estudo mais acabado sobre os fatores que possam afetar o conteúdo de oxalato no mate- 
rial vegetal, torna-se necessārio, uma vez que essa gramí nea è utilizada em grande escala na exploração bovina dos paises tropicais e sub tropicais.

$$
\text { os objetivos do presente trabalho são veri- }
$$
ficar os efeitos dos niveis crescentes da fertilização nitrogenada e potássíca sob o conteūdó de ácido oxálico do capim Setaria anceps. cv. Kazungula em condições de casa de veget ação. 


\section{RevisÃo de Literatura}

\subsection{Origem e Distribuiçäo Geogräbica}

o capim Setaria (Setaria anceps Stapf) faz parte de um grupo de espécie de gramíneas do gênero seta ria, Beauv, conhecido na Austrália como "complexo Setária". A espécie é.de origem africana, onde é encontrada natural mente dominando extensas áreas (LUCK, 1979) e é cultivada principalmente na Africa do Sul, Quenia, Rhodesia, Tndia, Filipinas, Japão, Taiwan, Austrālia, Estados Ụnidos da Amé rica (Flörida) e’Paraguai e, em condições de irrigação, no Marrocos e Israel (BOGDAN, 1977). No Brasil, segundo GOD1NHO (1968), foi introduzido no Estado de São Paulo, de 1953 a 1958, como capim de pastejo e capim para corte, através de material oriundo da Africa e, posteriormente, através de importações de semente da Austrālia, se difundiu para outras regiões do país. 


\subsection{Descriçäo da Espëcie}

As características botânicas e morfo-fisiológi cas da espécie, apresentam-na como uma planta perene, cespitosa, com crescimento entouceirado, podendo atingir no florescimento de 70 a $180 \mathrm{~cm}$. Apresentam caule tipo colmo ereto e com rizomas curtos. As folhas são geralmente largas, glabras com bainhas largas e quilhadas. Nas plantas novas, as bainhas das folhas são achatadas, fortemente comprimidas, dispostas em forma de leque e apresentam coloração purpürea. A inflorescência é de tipo panícula, racemosa, compacta e pseudo-espiga cilíndrica com ramificações secundärias muito curta e de coloração marrom, alaranjada ou amarela (LUCK,1970).

A espécie ainda não passou por um processo de melhoramento, o que explica a falta de pureza varietal, devido ao fato que quase completamente é de polinização cruzada. Assim, dentro de uma mesma cultivar, podem surgir plan tas com características bem distintas no porte, época de floração, e coloração de folhas. Apesar desta peculiaridade, não tem sido fator limitante para sua difusão (GODINHO,1969; LUCK, 1970; BOLDRINI, 1976; MENDONÇA, 1976; ABRAMIDES et alii, 1980 e PIMENTEL, 1983). 


\subsection{Cultivares}

\subsubsection{Nandi}

Material nativo, coletado no distrito de Nandi, Quenia e submetido a um programa de seleção. resultando um tipo de material bastante vigoroso e de floração tardia. Este cultivar possui rizoma muito curto, colmo ereto forman do touceira com uma altura de até $1,50 \mathrm{~m}$ no alto da inflores cência (LUCK, 1979). A inflorescência tipo panícula, de 'dimensões variáveis, apresenta uma tonalidade escura que vai de uma coloração marrom-esverdeada ou marrom-alaranjada. 0s afilhos apresentam uma coloração verde amarelada, achatada na base e de cor purpürea na parte basal da bainha basal. E uma planta diplöide com nümero de cromossomos $2 n=18$. (HACKER e JONES, 1969; ALCÂNTARA et alii, 1979; PIMENTEL et alii, $1983)$.

\subsubsection{Kazungula}

E um ecotipo nativo de Zambia e desenvolvido para pastagem e produção de feno. Foi introduzido na Austrālia em 1949 de material proveniente de Pretoria e em 1962 foi lançada em escala comercial, a cultivar Kazungula dife rente da Nandi por apresentar inflorescência de cor mais cla ra, folhas verde azuladas e de porte maior, podendo atingir altura superior a $2,00 \mathrm{~m}$ na inflorescencia. As bainhas das folhas basais dos afilhos apresentam uma coloração purpúrea 
menos acentuadas que a Nandi, e os nös do colmo são de um vermelho ma is pälido. E uma planta tetraplóide com nūmero. de cromossomos $2 n=36$. Apresenta polinização cruzada com a Narok mas não com a Nandi (HACKER e JONES, 1969; LUCK, 1970).

\subsubsection{Narok}

Foi selecionada de introduções feitas de Aber dares, região do Kenya, e introduzido na Austrälia no ano de 1963. o material foi submetido a um programa de seleção a fim de obter uma maior adaptação a geadas e maior produção no inverno, o resultado desse trabalho resultou a liberação da setaria Narok a nível comercial. Difere especialmen te da Nandi por ser de maior porte, menos vigorosa que a Kazungula da qual difere por sua coloração verde mais acentuada. Na florą̧ão pode atingir até $1,80 \mathrm{~m}$ de altura. Ọs perfilhos são mais largos do que a Nandi e em algumas plantas podem faltar a pigmentação purpūrea da base, comum na Nandi e Kazungula. E uma planta tetraplöide, com nümero de cromosso mos. $2 n=36$. A cultivar Narok pode ter uma polinização cruza da com a Kazungula mas não com a Nandi (HACKER e JONES, 1969; LUCK, 1979).

\subsection{Exigências climäticas e Edäficas}

Entre as exigências climäticas, destaca-se a temperatura como um dos fatores limitantes ao crescimento das 
espécies tropicais e sub-tropicais. Segundo HACKER e JONES (1969), para um ötimo crescimento da setaria, são exigidas temperaturas médias superiores a $20^{\circ} \mathrm{C}$. KEMP (1976) na Austrälia considerou a temperatura como um fator de grande importância do início ao fim do crescimento de três espécies,

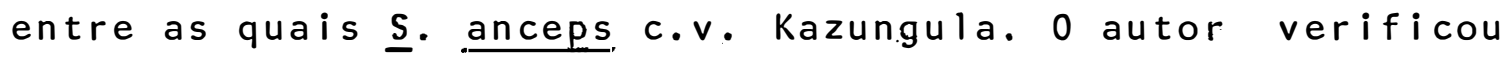
que o crescimento iniciou quando as temperaturas mēdias diă rias foram de $13^{\circ}-15^{\circ} \mathrm{C}$ na primavera e cessou nos dois anos seguintes no outono, com temperaturas de $12-14^{\circ} \mathrm{C}$.

Num terceiro ano, porēm, quarido as temperaturas decresceram gradualmente, o crescimento não cessou atē $6-12^{\circ} \mathrm{C}$. DEINUM e DIRVEN (i977) estudando três regimes de temperatura dia/ noite $\left(23 / 18^{\circ} \mathrm{C}, 29 / 23^{\circ} \mathrm{C}, 31 / 27^{\circ} \mathrm{C}\right)$, verificaram que a temperatura ótima para o crescimento de $\underline{\mathrm{S}}$. anceps foi de $29 / 23^{\circ} \mathrm{C}$. Com respeito a baixas, temperaturas JONES (1969) relatou uma alta porcentagem $(91 \%)$ de sobrevivência das plantas. En tretanto, BARNARD (1972) alertou que ocorrem pequenos danos nas folhas a temperatura de $-2,8$ a $3,3^{\circ} \mathrm{C}$, e que abaixo dessa temperatura pode ocorrer a morte das folhas. Já HACKER et ali i (1974) indicam que dentre as três cultivares mais difundidas a que apresenta maior tolerância à geada é a Narok, seguindo-se a Kazungula e a Nandi.

Um outro fator importante è a precipitação pluviométrica. Segundo KEMP (1976), trabalhando com $\underline{S}$. anceps c.v. Kazungula, afirmou que a irrigação teve apenas um leve efeito sobre o crescimento e que, em periodos secos, a 
queda na taxa de crescimento foi máxima com pouco nitrogênio e baixas temperaturas. Na Austrälia, onde estas plantas são amplamente cultivadas, melhor se adaptaram às regiões de climas tropicais e sub-tropicais de maior semelhança com as condições de origem (LUCK, 1979). Nesse país, segundo o mesmo autor, a Kazungula é comumente plantada nas áreas com precipitação anual em torno de $750 \mathrm{~mm}$, enquanto que a Nandi e a Narok são recomendadas principalmente para äreas com precipitação superior a $1.000 \mathrm{~mm}$.

No Brasil., trabalhos feitos por GODINHO et ali i (1968) em regiões que abrangem uma larga fàixa climáti ca, concluiram que a Setaria anceps c.v. Kazungula, è um capim razoavelmente resistente à seca è geada, vegetando com grande intensidade no verão, chegando rapidamente à altura de 40 a $50 \mathrm{~cm}$, dando boa quantidade de massa verde. Ou tros trabalhos feitos nos Estados de Mato Grosso do Sul, Goịás, Minas Gerais (PERElRA et alii, 1966; PIMENTEL, 1979) São Paulo, Páraná (ABramldes et ali i , 1980) Rio Grande: do Sul. (KohmAN e ÁVILA, 1979), e Amazônia e Pantanal (CANTO et alii, 1979, CUNHA et alii, 1981) confirmam a ampla faixa de adaptação climätica da espēcie e em especial a cultivar Kazungula.

No Paraguai MOLAS et alii (1982) estudando a adaptação e comportamento agrostológico de gramíneas e legu minosas nas condições de estação experimentao do Chaco encon 
traram que a $\underline{\mathbf{s}}$. anceps c.v. Kazungula teve um bom comportamento em condições de prolongada inundação, confirmando as pesquisas feitas por ABRAMIDES et alii (1980) que a cultivar Kazungula é mais adaptada a solos rasos do que a Nandi e mais tolerante a períodos prolongados de encharcamento.

Em termos de solo, a espécie adapta-se bem ao mais variados tipos. Na Austrālia, segundo LUCK (1979), é cultivada em diversos tipos de solos, bem ou mal drenados, especialmente naqueles de mediana e boa fertilidade e com um pH variando de 5,0 a 7,0.

Em um estudo comparativo entre gramíneas, SMITH (1979) encontrou que a setaria possui uma considerável tolerância aos solos äcidos, e apresenta boas respostas a fertilizantes quando cultivada em solo de baixa fertilidade.

No Brasil, as pastagens de setaria geralmente sao utilizadas em solos àcidos e de baixa produtividade como do cerrado, e tem apresentado bons resultados em prodú ção animal em especial a cultivar Kazungula (PIMENTEL et alii, 1979; NUNE et alii, 1979).

\subsection{Produtividade.}

0 potencial de produção de forragem do capim setaria, como nas demais gramíneas forrageiras tropicais, è 
influenciado pelas condições climāticas, temperatura, fotoperíodo e precipitação edăfica, entretanto, a taxa de crescimento está marcadamente influenciada pela fertilidade e tipo de solo. 0 período de produção, nas regiões tropicais iniciase na primavera e se estende até o outono, quando a tempera tura começa a baixar (PEDREIRA, 197.3; LUCK, 1979). Na Austrālia, KEMP (1976) verificou também que o crescimento iniciou-se quando as temperaturas médias diārias foram de 13$15^{\circ} \mathrm{C}$ na primavera e cessou nos dois anos seguintes no outono, com temperatura de $12-14^{\circ} \mathrm{C}$.

A Setaria anceps desenvolve grande nümero de perfilhos. BOONMAN (1971) encontrou cerca de 1.900 perfilhos/. metro quadrado, sendo que em outras gramíneas, o nümero de perfilhos por metro quadrado variou de 1.280 a 1.800 .

Nas āreas de cultivo da setária, na Austrā lia, a produtividade média anual de matéria seca da espécie é cerca de $10 \mathrm{t} / \mathrm{ha}$, atingindo $27 \mathrm{t} / \mathrm{ha}$ com irrigação (HUMPHREYS, 1974).

STRICKLAND (1978) estudando as produções

anuais e de inverno de vārias gramíneas, encontrou "que o rendimento anual de $18.330 \mathrm{~kg} / \mathrm{ha}$ de matéria seca da setäria e a produção de $2.870 \mathrm{~kg} / \mathrm{matéría} \mathrm{seca/ha} \mathrm{durante} \mathrm{a} \mathrm{estação}$ fria, confirmam as afirmações feitas por outro pesquisadof austräliano (HACKER; 1972) da resistência dessa espécie à baixa temperatura. 
No Brasil, PEREIRA et ali $(1966)$, estudando a competição de 10 gramíneas para capineiras no cerrado, encontrou que a Setária produziu 70 t/ha de matēria verde no veräo chuvoso, mas apenas 5 t/ha durante o inverno seco.

PEREIRA et ali i (1975) comparando a produção da matéria seca a $65^{\circ} \mathrm{C}$ de uma competição de capins encontrou que a setaria anceps. c.v. Kazungula tinha rendimento de 12,5 t/ha/ano sendo a de terceira maior produção. Outras pesquisa dores como KOHMAN et alii (1979) e CASTILLO et alii (1981), obtiveram produções anuais da matēria seca e proteína bruta que variou de 8,5 a 9,9 t/ha 7,3 a $8,2 \%$, respectivamente.

\section{No Paraguai estudos feitos por HEYN e.MOREL}

(1982) sobre o rendimento de três gramíneas cultivadas encontraram que a produção de setaria anceps c.v. Kazungula atingiu um rendimento de 9,3 t/ha/ano de mä̈ēria seca e $8,4 \%$ de proteína bruta.

Na Tabela l se apresentam um resumo dos trabalhos citados.

\subsection{Respostas a Fertilizantes}

Muitos trabalhos com gramíneas tropicais indicam que os máximos rendimentos tanto em quantidade como em qualidade são obtidos com uso de adubos, principalmente nitrogenado. Trabalho feito no Sul da Africa por MALHERBE(1969), 
Tabela 1 - Produtividade do capim setaria

\begin{tabular}{lcc}
\hline Autor. & $\begin{array}{c}\text { Matéria Seca } \\
\text { t/ha/ano }\end{array}$ & $\begin{array}{c}\text { Matéria Verde } \\
\text { t/ha/ano }\end{array}$ \\
\hline HUMPHREYS (1974) & 10,0 & - \\
STRICKLAND (1978) & - & 18 \\
PEREIRA et alii (1966) & 12,5 & 70 \\
PEDREIRA (1973) & 8,5 & - \\
KOHMAN et alii (1979) & 12,6 & - \\
CASTILLO et alii (1981) & 9,3 & - \\
HEYN e MOREL (1982) & & - \\
\hline
\end{tabular}

encontrou produçōes de forragem, 7,2 t/ha de matēria seca e 6,59\% de proteína bruta, com o uso de fertilizações nitroge nada e fosfatada. Dados citados por HACKER e JONES (1969) e BOGDAN (1977) mostram que a setaria produz em torno de $30 \mathrm{~kg}$ de matéria seca por quilograma de $\mathrm{N}$ aplicado; mas segundo es ses mesmos autores, essa produção pode ser superior a $50 \mathrm{~kg}$.

$$
\text { OLSEN (1972) trabalhando em Uganda com quạ }
$$
tro gramíneas tropicais, entre elas a Setaria anceps a tes tando o efeito de pesadas aplicações de nitrogēnio, concluiu que todas as gramineas responderam fortemente ao nitrogênio até $448 \mathrm{~kg} / \mathrm{ha}$, e com um leve acréscimo até os $896 \mathrm{~kg} / \mathrm{ha}$. Ac ma desta dose houve um declínio no rendimento da matéria se 
ca. Os rendimentos de Setaria anceps foram de $7,6,17,7$, 19,3, e 22,0 tha de MS; respectivamente, com $0 ; 224 ; 448$ e $896 \mathrm{~kg} / \mathrm{ha}$ de $\mathrm{N}$, e com $7,8,9,6,11,9$ e $14,9 \%$ de proteína bruta na matéria seca, respectivamente (Tabela 2 ).

TIHARUHONDI e MUSANGI(1973) em Uganda estudando a aplicação de $\mathrm{N}$ e a irrigação da pastagem na produção de gado durante a estação seca concluiu que para ambas as cond ções de pastagem irrigada e não irrigada, a aplicação de nitrogênio incrementou substancialmente a produção de matéria seca, da proteina bruta e decréscimo na composição de fibra bruta. KEMP (1975) com $170 \mathrm{~kg} / \mathrm{ha}$ de $\mathrm{N}$, encontrou produção de 29. kg de matéria seca para cada kg de $\mathrm{N}$ aplicado. Dados obtidos por PEDREIRA et alii (1975) em solo arenoso, com uma adubação de plantio de $40,100,60 \mathrm{~kg} / \mathrm{ha}$, respectivamente, de $\mathrm{N}, \mathrm{P}_{2} \mathrm{O}_{5}$ e $\mathrm{K}_{2} \mathrm{O}$, obtiveram produções anuais de matēria seca de 12,6 t/ha com $5,7 \%$ de proteina bruta o que evidenciou a capacidade produtiva da espécie, comparativamente com outras gramineas forrageiras. PIMENTEL (1976) obteve, em plantas da cultivar Kazungula de Setaria anceps rendimentos de 4.580, 5.440 e $6.170 \mathrm{~kg} / \mathrm{ha}$ de matéria seca nas doses de 0,100 e $200 \mathrm{~kg} / \mathrm{ha}$ de $\mathrm{N}$, respectivamente.

KEMP (1976) na Austrälia, com Setaria anceps. c.v. Kazungula verificou que com $680 \mathrm{~kg} / \mathrm{ha}$ de $\mathrm{N}$ por ano o crescimento iniciou em setembro e parou em maio-junho e também que uma taxa de crescimento maior que $60 \mathrm{~kg} / \mathrm{ha}$ de maté- 
ria seca por dia ocorreu durante quatro a seis meses. Já para $170 \mathrm{~kg} / \mathrm{ha}$ de $\mathrm{N}$ por ano o crescimento iniciou-se em outubro e foi até abril-maio e com uma taxa de crescimento superior a $60 \mathrm{~kg} / \mathrm{ha}$ de matēria seca por dia num periodo de 1 a 2 semanas. No tratamento sem nitrogênio, o crescimento só foi iniciado no veräo.

Dados obtidos por EBERSOHN e MULDER (1980), na Austrālia, evidenciaram produções de matēria seca e de pro teína bruta até o nível de $896 \mathrm{~kg} / \mathrm{ha}$ de $\mathrm{N}$ (Tabela 2).

Tabela 2 - Produção anual de matēria seca e de proteína bruta de Setaria anceps. c.v. Nandi e Kazungula com adubação nitrogenada

\begin{tabular}{ccccc}
\hline \multirow{2}{*}{ Cultivares } & \multicolumn{2}{c}{ Doses de Nitrogênio } & (kg/ha/ano) \\
\cline { 2 - 5 } & 0 & 224 & 448 & 896 \\
\hline
\end{tabular}

NAND I

OLSEN (1972)

$\begin{array}{lrrrr}\text { Matēria seca (t/ha) } & 7,6 & 17,7 & 19,3 & 22,0 \\ \text { Proteína Bruta (\%) } & 7,8 & 9,6 & 11,9 & 14,7\end{array}$

KAZUNGULA

EBERSOHN E MULDER. (1980)

$\begin{array}{lllll}\text { Matéria seca }(\mathrm{t} / \mathrm{ha}) & - & 8,0 & 9,5 & 10,0 \\ \text { Proteína bruta (\%) } & - & 1,7 & 2,1 & 2,3\end{array}$


Na Austrālia, o nitrogênio via fertilizante ou leguminosa, através da capacidade de fixação simbiötica dessas plantas, tem sido utilizado com sucesso para aumentar - a disponibilidade e valor nutritivo de pastagens no inverno.

A setaria, devido a seu hábito de crescimento entouceirạdo e a larga relação haste-folha facilita a pene tração de raios luminosos até a superfície do solo, permitin do boa consorciação com leguminosas herbáceas tropicais, tais como: siratro, soja: perene, centrosema, galaxia e calopogonio.

Segundo BOGDAN (1977) a produção da mistura de leguminosa com Setaria anceps raramente incrementa a produção da gramínea, entretanto, a produção de matéria seca e proteina bruta é incrementada na mistura comparativamente com a gramínea crescendo sozinha.

MIDDLETOW (1970) estudando alguns aspectos so bre a taxa de semeadura de uma mistura de leguminosas e gramíneas sobre a produção da pastagem e composição química relatou que o incremento de semeadura de uma espécie geralmente aumenta a produção, mas não em forma proporcional, porém causa uma diminuição na produção do componente associado. En tretanto, THlaRU (1972) estudando a contribuição do Desmodium uncinatum para a produção de Setaria anceps. verificou que a produção total de matéria seca $(9.860 \mathrm{~kg} / \mathrm{ha})$ e produção de nitrogênio ( $210 \mathrm{~kg} / \mathrm{ha})$ da mistura foram consistentẹ 
mente mais alto do que a gramínea crescendo sozinha cuja pro dução de matéria seca e nitrogênio foram 6.734 e $112 \mathrm{~kg} / \mathrm{ha}$, respectivamente.

$$
\text { Enquanto a șetaria aparentemente não è uma }
$$
planta muito exigente, em fósforo, exceto no estabelecimento, este elemento, segundo BOGDAN (1977), promove um maior e mais räpido desenvolvimento inicial da planta.

MALHERBE (1969) não observou respostas a altas aplicações de $P$, exceto quando combinada com $N$. Neste ex perimento, que foi conduzido com a cultivar Kazungula em solo de baixa fertilidade, foram utilizadas doses que variaram de 0 a $636 \mathrm{~kg} / \mathrm{ha}$ de $\mathrm{P}_{2}{ }{ }_{5}$. Com esta ültima dosagem e sem $\mathrm{N}$, as produções foram 4,4 t/ha de matéria seca, contra 17,7 t/ ha com N (Tabela 3).

Tabela 3 - Produção de feno de Setaria anceps c.v. Kazungula em função de adubação fosfatada e nitrogenada.

\begin{tabular}{|c|c|c|c|}
\hline \multirow{3}{*}{$\begin{array}{c}\mathrm{P}_{2} \mathrm{O}_{5} \\
(\mathrm{~kg} / \mathrm{ha} / \mathrm{ano})\end{array}$} & \multicolumn{2}{|c|}{ Doses de nitrogênio } & ( $\mathrm{kg} / \mathrm{ha} / \mathrm{ano})$ \\
\hline & 0 & 397 & 1,590 \\
\hline & Produção de & feno & (t/ha/ano) \\
\hline 0 & 4,6 & 8,3 & 14,9 \\
\hline 318 & 4,5 & 9,1 & 16,5 \\
\hline 636 & 4,4 & 10,4 & 17,7 \\
\hline
\end{tabular}

FONTE: MALHERBE. (1.969) 
Quanto ao potássio (K), alguns estudos têm evidenciado que este elemento parece ser muito importante pạ ra a setaria, notadamente quando em consorciações com legum nosas. Segundo BOGDAN (1977) sua ap.licação é essencial quando o conteúdo no tecido da planta é inferior a $1 \%$.

0 efeito de outros elementos tem sido pouco explorados. Na Africa do Sul, De Bruyn e Mclbrath (1966), ci tados por BOGDAN (1977) observaram que dentre quatro micronutrientes estudados, apenas manganês, e, aparentemente, bor revelaram-se mais exigidos para o crescimento normal de setá ria Kazungula. No mesmo estudo não foram observados sintomas de deficiência de cobre e zinco na.planta não adubada com esses nutrientes, ocorrendo sintomas de deficiencia de manganês e boro quando os niveis desses elementos no solo eram inferiores a 0,5 e 0,001 ppm, respectivamente. Severo decrēscimo na produção de matēria seca, em função de limitações de enxôfre foram observados por CASAGRANDE e CoRREA (1980).

\section{7. valor Nutritivo}

o valor nutritivo ou qualidade das plantas

forrageiras é, sem dūvida, um dos mais importantes fatores relacionados com a produção animal a ser obtida nas pastagens.

A setaria quando nova apresenta bom valor nu- 
tritivo e alta aceitabilidade pelos animais, contudo, ao atingir o estado de florescimento, seu conteüdo em nutriente e palatabilidade são relativamentébaixos.

A composição química e bromatológica da forrạ gem, além de variar com o estado de desenvolvimento da plan ta e época do ano em que se coleta a amostra pode ainda ser influenciada pela altura e frequência de corte ou pastejo.

Resultado de anālise bromatológica e química apresentados por SHARMA et àlii (1972) são mostrados na Tabela 4.

Tabela 4 - Composição química da matéria seca de Setaria anceps $(\%)$

\begin{tabular}{llllllll}
\hline $\begin{array}{c}\text { Matéria } \\
\text { Seca }\end{array}$ & $\begin{array}{c}\text { Proteína } \\
\text { Bruta }\end{array}$ & $\begin{array}{c}\text { Extrato } \\
\text { Etéreo }\end{array}$ & $\begin{array}{c}\text { Fibra } \\
\text { Bruta nitrogenado }\end{array}$ & $\begin{array}{c}\text { Extrato } \\
\text { Não }\end{array}$ & Cảlcio & Fósforo \\
\hline 16,00 & 10,50 & 2,14 & 26,35 & 48,66 & 12,35 & 0,53 & 0,43 \\
\hline
\end{tabular}

FONTE: SHARMA et alii (1972)

Na Austrália, STOBBS (1973) constatou que apesar da digestibilidade dessa forrageira ser ligeiramente mais baixa que a dos capins Pangola e Rhodes, não houve diferenças marcantes quanto ao teor de $\mathrm{N}$ e de outros componen tes químicos analisados (Tabela 5).

GRIEVE e OBBOURN (1965) e SONEJI et alii(1971) estudando o valor nutritivo de algumas gramíneas tropicais encontraram que. Setaria anceps c.v. Nandi, à medida que au- 
mentava o estado de maturidade o potencial da matéria seca sofria um incremento, entretanto, a quantidade de proteína bruta e o coeficiente de digestibilidade diminuía (Tabela 6).

Como nas demais forrageiras, o valor nutritivo de setaria é relativamente mais alto nas folhas do que nas demais partes da planta e nas plantas novas do que nas velhas. Resultados obtidos por WIJK (1976) demonstraram que digestibilidade do caule e folhas de Nandi foi similar com até nove semanas dé crescimento da planta, variando de 56 a $60 \%$, enquanto que, com quinze semanas, baixou para cerca de $50 \%$ nas folhas e $36 \%$ no caule.

\subsection{Problemas Relacionados com Setaria anceps}

Trabalhos realizados por MATHAS e SUTHERLAND (1952), GARCIA-RIVERA (1955) mostraram que a setaria anceps. contēm oxalatos. A essa substância que frequentemente è depositada em vārios ōrgäos da planta ou em célulias especializadas na forma de oxalato de cálcio, sódio e de potássio (JQ NES e FORD, 1972; MCDONALD, 1982), foram atribuídos casos de intoxicação dos bovinos (JONES et alii, 1970; SEAWRICllt et alii, 1970; GONZALEZ e COWARD, 1977; WARD et alii, 1979. e SHENK et alii, 1982), eqUinos (GROENENDYK e SEAWRIGHT, 1974; WALTHALL e MCKENZIE, 1976; BLANEY et alii, 1981a; BLANEY et ali i, $1981 \mathrm{~b}$; GARTNER et alii, 1981; MCKENZIE et alii, 1981 e HINTZ 
Tabela 5 - Digestibilidade e composição química da matéria seca (M.S.) de pastagens de pangola (Digitaria decumbens), capim Rhodes (Chloris gayana) e setaria (Setaria anceps)

\begin{tabular}{|c|c|c|c|c|c|c|c|}
\hline \multirow{2}{*}{ Pastagem } & \multirow{2}{*}{$\begin{array}{c}\text { Diges- } \\
\text { tibili } \\
\text { dade } \\
(\%) \\
\end{array}$} & \multicolumn{6}{|c|}{ Composição Química da M.S. (\%) } \\
\hline & & $\mathrm{N}$ & $P$ & K & $\mathrm{Ca}$ & $\mathrm{Mg}$ & $\mathrm{Na}$ \\
\hline Pangola & 59,1 & 2,25 & 0,24 & 2,14 & 0,34 & 0,22 & 0,98 \\
\hline Rhodes & 57,4 & 2,14 & 0,22 & 1,66 & $0 ; 40$ & 0,16 & 1,08 \\
\hline Setaria & 55,0 & 2,16 & 0,25 . & 2,78 & 0,30 & 0,20 & 0,85 \\
\hline
\end{tabular}

FONTE: STOBBS (1973).

Tabela 6 - Conteúdo da matéría seca, proteína bruta e coeficiente de digestí bilidade aparente da matéria seca, e energia total e proteína bru ta da Setaria anceps em diferentes idades de rebrota e maturidade

\begin{tabular}{|c|c|c|c|c|c|c|c|}
\hline \multirow[b]{2}{*}{ Espécie } & \multirow{2}{*}{$\begin{array}{l}\text { Idade } \\
\text { de } \\
\text { rebrota } \\
\text { (semana) }\end{array}$} & \multirow{2}{*}{$\begin{array}{c}\text { Estado } \\
\text { de } \\
\text { Maturi- } \\
\text { dade }\end{array}$} & \multirow[b]{2}{*}{$\begin{array}{c}\text { Matéria } \\
\text { seca } \\
(\%)\end{array}$} & \multirow[b]{2}{*}{$\begin{array}{c}\text { Proteina } \\
\text { bruta } \\
(\%)\end{array}$} & \multicolumn{3}{|c|}{$\begin{array}{l}\text { Coeficiente de } \\
\text { Digestibilidade }\end{array}$} \\
\hline & & & & & $\begin{array}{l}\text { Matēria } \\
\text { seca } \\
(\%)\end{array}$ & $\begin{array}{l}\text { Proteina } \\
\text { bruta } \\
(\%)\end{array}$ & $\begin{array}{c}\text { Energia } \\
\text { total } \\
(\%)\end{array}$ \\
\hline
\end{tabular}

Setaria

\begin{tabular}{|c|c|c|c|c|c|c|c|}
\hline anceps & 4 & imaturo & 14,8 & 10,5 & 68,2 & 69,4 & 69,8 \\
\hline$c . v$. & 6 & imaturo & 15,6 & 8,6 & 56,5 & 53,6 & 55,3 \\
\hline Nandi & 8 & imaturo & 19,0 & 4,8 & 56,3 & 44,0 & 55,3 \\
\hline
\end{tabular}

FONTE: GRIEVE E OBBOURN (1965). 
et alii, 1984) e ovinos (WATTS, 1959; DOBSON, 1959 e ALLISON et alii, 1977).

A ingestão excessiva de oxalatos, acima de $5 \%$ na matéria seca (LUCK, 19́79), causa certa irritação gastrointestinal, contração muscular ou tetania acompanhada por outros sintomas nervosos, devido à remoção do íon $\mathrm{Ca}^{++}$do sistema orgânico, um desarranjo do balanço bāsico $\mathrm{Ca} \mathrm{Mg/N}$ a K, capacidade de coagular diminuida do sangue devido ao decréscimo do ion Ca; lesões nos örgãos excretores, rins, etc. devido à deposição de substância celular de grande concentra çōes de oxalato de cālcio cristalino (SMITH, 1972).

Num estudo dos níveis de oxalato total e solūvel em àgua, em quinze espécies.de forrageiras dos distritos de Lango e Acholi em Uganda, NDYANABO (1971) determinou que a Setaria anceps, c.v. Nandi e Pennisetum purpureum cont nham níveis mais altos de oxalato insolúvel e solüvel em ăgua que as demais gramíneas. De acordo com a anālise para o conteūdo de Ca.e N. não houve relacionamento entre o teor de oxalato com $\mathrm{Ca}$ e $\mathrm{N}$ nas gramíneas. Duas leguminosas Centro sema pubescens e Stylosanthes gracilis mostraram um conteūdo levemente mais alto de oxalato total $(2,22$ e $1,72 \%$, respecti vamente) e apesar de possuírem alto teor de Ca e N $(1,91$; 3,10 e 1,18 e $2,72 \%$, respectivamente) apresentavam um baixo teor de oxalato solüvel (Tabela 7). 
Tabela 7 - Mēdia de oxalato total e solūvel em água e contẹ̆ do de Cālcio (Ca) e Nitrogēnio (N) (\% de M.S.)

\begin{tabular}{|c|c|c|c|c|}
\hline \multirow{3}{*}{ Espëcie } & \multicolumn{2}{|c|}{ Ácido $0 \times a ̄ l i c o$} & \multirow[b]{2}{*}{ Cälcio } & \multirow{2}{*}{$\begin{array}{l}\text { Nitro- } \\
\text { gênio }\end{array}$} \\
\hline & Total & $\begin{array}{l}\text { Solūvel } \\
\text { em āgua. }\end{array}$ & & \\
\hline & $(\%)$ & $(\%)$ & $(\%)$ & $(\%)$ \\
\hline . & & 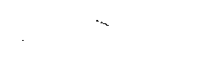 & & \\
\hline Setaria anceps & 3,79 & 3,22 & 0,44 & 1,90 \\
\hline Pennisetum purpureum & 3,10 & 2,59 & 0,39 & 2,00 \\
\hline Centrosema pubescens & 2,22 & 0,10 & 1,91 & 3,10 \\
\hline Stylosanthes gracilis & 1,72 & 0,15 & 1,18 & 2,72 \\
\hline
\end{tabular}

FONTE: NDYANABO, 1974.

A variação na acumulação de oxalato na seta ria está largamente associada com sua ārea de órigem. Introduções originärias do Sul e do Oeste da Africa tendem a acumular mais oxalato que aquelas originărias do Quenia. Entretanto, todas as introduções do Quenia foram pouco produtivas em comparação às do Sul da Africa, Tanzânia e Uruguai. Porēm, o ūnico grupo que combinou uma produção relativamente alto e um baixo teor de oxalato foi do Quenia, o qual incluia a cultivar Nandi.

As concentrações de $\mathrm{Na}$ e K foram negativamente correlacionadas $(r=0,43 ; P<0,01)$ nas introduções provenientes de Quenia. Correlações altas $(r=82 ; P<0,001)$ entre oxalato de $\mathrm{Na}$ e concentração de $\mathrm{Na}$ foram encontrados, mas não houve significãncia na correlação entre oxalato de $K$ e concentração de $K(r=0,07)$ : 
O relacionamento entre oxalato de $\mathrm{Na}$ e $\mathrm{K}$ foi classificado quando ambos os cátions (somados como mEq\%) foram sumarizados comparando com o oxalato. A alta correlação - $(r=0,93)$ entre oxalato de $N a$ e $K$ indica que a variação está intimamente associada com a absorção de cátions.

A citada correlação estimada entre concentração de $\mathrm{Na}$, e oxalato de $\mathrm{K}$ e matéria seca digestível, sugere que as introduções de setaria, com altos valores de matēria seca digestível devem algo de sua superioridade ao alto teor de oxalato.

HACKER (1974) conclui que existe um complexo inter-relacionamento entre concentração de cātions, concen tração de oxalato, produção de matéria seca e digestibilidade.

Essas afirmações coincidem com os trabalhos feitos por SMITH (1972), onde o aumento da concentração de ácido oxálico, nas três cultivares de Setaria, foi proporcio nal a diferenças entre nível de cātions $\left(\mathrm{K}^{+}, \mathrm{Na}^{+}, \mathrm{NH}_{4}^{+}, \mathrm{Ca}^{2+}\right.$ e $\left.\mathrm{Mg}^{2+}\right)$ e ânions $\left(\mathrm{Na}_{3}^{-}, \mathrm{Cl}^{-}, \mathrm{H}_{2} \mathrm{PO}_{4}\right.$ e $\left.\mathrm{SO}_{4}\right)$ no fluido celular Pa ra manter sua eletroneutralidade. Tais características seriam próprias da Setaria anceps na sintese e acumulação de oxalato solüvel como seus íons orgânicos, em maior quantidade para manter o equilíbrio cátions-ânions (DIJKSHOORN, 1973). 
de adubação nitrogenada e potássica, pois, com maior disponi bilidade e absorção de cátions, acumularia mais oxalato.

JONES E FORD (1972) tratando de obter informação sobre os possiveis fatores que afetam o conteūdo de oxalato na Setaria anceps realizaram três experimentos: no primeiro, buscaram medir o efeito da adubação nitrogenada (uréia) na composição minerál e o teor de oxalato da Setaria anceps, concluindo que o oxalato era $69,7 \%$ mais alto no canteiro adubado com urēia que : o não adubado. Este resultiado coincidiu com niveis mais altos de $\mathrm{N}$ e Mg e com uma tendên cia para valures mais altos de $K$ e $N a$ na matéria seca. Uma alta correlação entre concentração de oxalato com a soma dos cátions totais e com a soma de $\mathrm{Na}$ e K na matéria seca (Tabela 8).

Tabela 8 - 0 efeito da fertilização com urēia sobre o oxalato e a composição mineral do $\underline{S}$. anceps c.v. Kazun gula

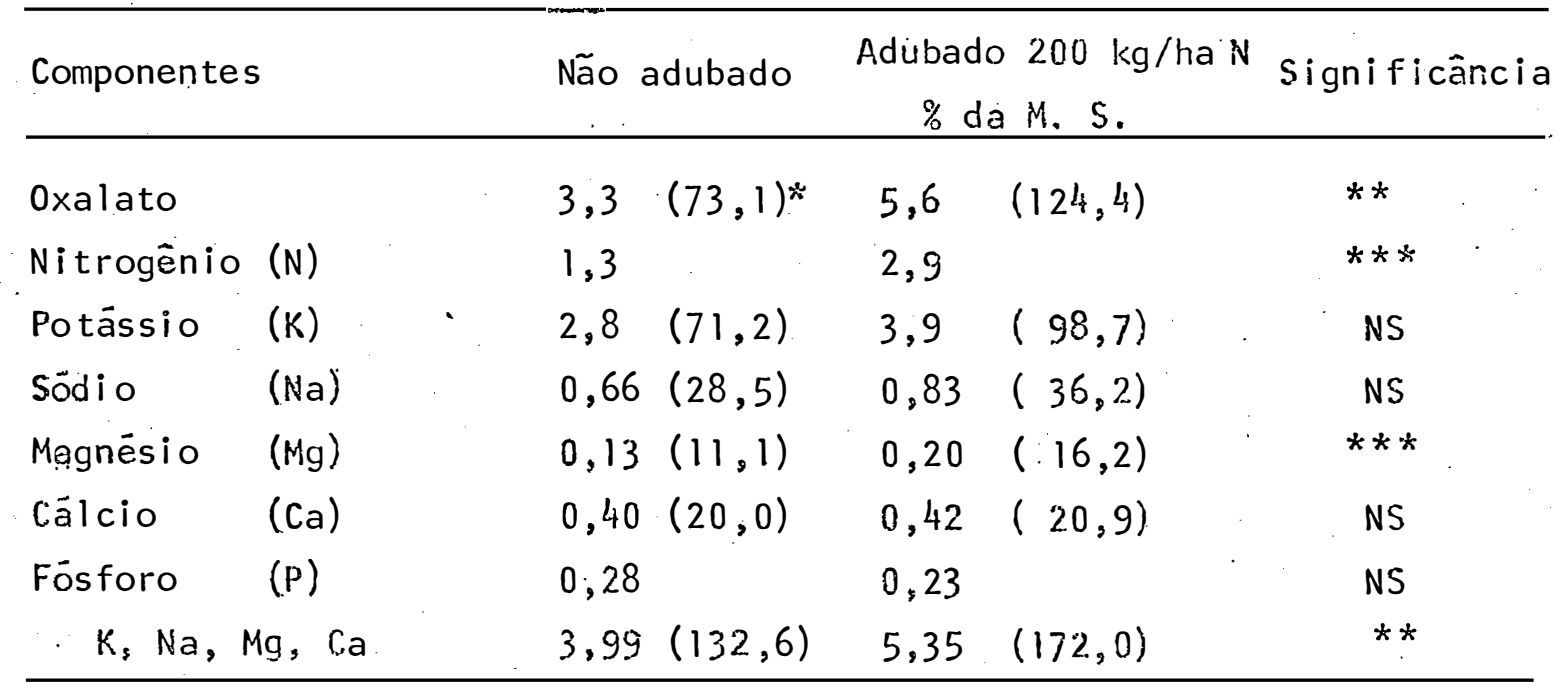

FONTE: JONES E FORD (1972)

$$
\begin{aligned}
& *-m c q / 100 g ; * * *-P<0,001 ; \\
& * *-P<0,01 ; \text { NS - não significativo. }
\end{aligned}
$$


$\because$ No segundo experimento os mesmos autores mediram o efeito da adubação nitrogenada na composição de oxalato da matéria seca na rebrota de outono e primavera, concluindo que os picos mais altos de oxalato foram obtidos para a rebrota de outono do que para a rebrota de primavera, para todos os níveis de N (Tabela 9). Os valores baixos na primạ vera comparados com o conteúdo no outono coincidem com os baixos valores de sódió e potássio. A essa mesma conclusão chegaram MIDDLETON e BARRY (1978) que encontram uma correlação positiva entre oxalato e nitrogênio.

No terceiro experimento, medindo os efeitos de altos e baixos níveis de $N$ e K, usando como fontes de $N$, urēia e para $\mathrm{K}, \mathrm{KCl}$ e $\mathrm{K}_{2} \grave{\mathrm{S}}_{4}$, concluiram que houve uma variação na composição de oxalato quanto às duas fontes de $K$, sen do que a maior taxa foi encontrada quạdo se usou KCl (155 $\mathrm{kg}$ de $\mathrm{K} / \mathrm{ha}$ ) e urēia (50 kg de $\mathrm{N} / \mathrm{ha}$ ) (Tabela 10).

Os mesmos autores estudaram o conteūdo de oxalato nas partes das plantas e as variações diurnas e noturnas, concluindo que os niveis de oxalato nas partes das plantas num estádio de cinco semanas de rebrota, obedeciam a seguinte ordem: lâmina de folha maior que bainha de folha, maior que hastes, maior que inflorescência (Tabela 11).Quanto as variações diárias o teor de oxalato é mais alto à noit.e enquanto que ao redor do meio dia encontram-se os niveis mais baixos (Gräfico 1 ). 


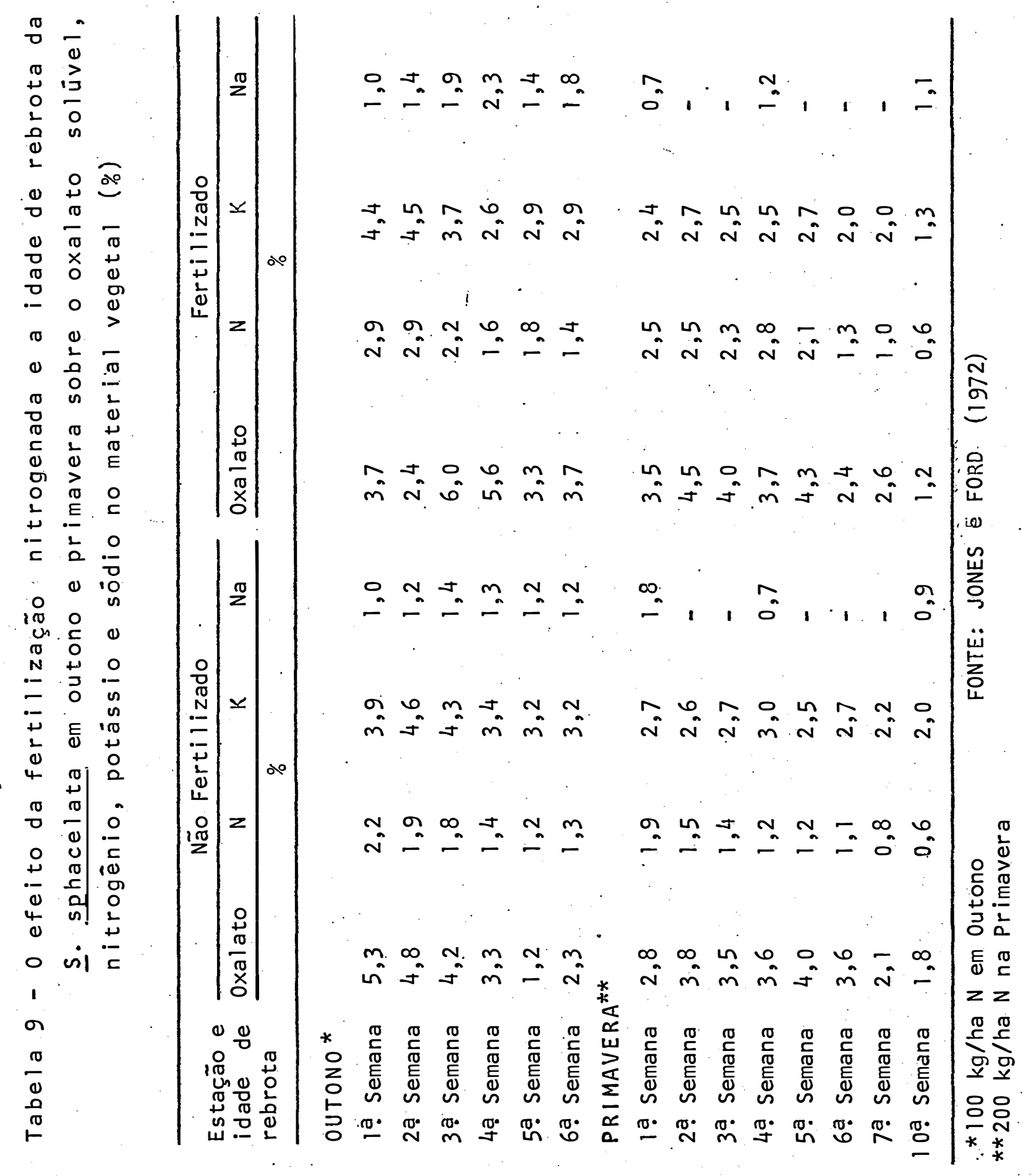


Tabela 10 - Efeito da fertilização nitrogenada e potássica sobre o conteúdo de oxalato de Setaria anceps.

\begin{tabular}{|c|c|c|c|}
\hline \multirow{3}{*}{$\begin{array}{l}\text { Forma e } \\
\text { Nivel de } K\end{array}$} & \multicolumn{2}{|c|}{ Conteüdo de 0xalato com: } & \multirow{3}{*}{ Mēdia } \\
\hline & Baixo N ${ }^{* *}$ & Al to $\mathrm{N}$ & \\
\hline & $\% d a$ & & \\
\hline
\end{tabular}

$\mathrm{KC} 1$

$\begin{array}{ll}\text { Baixo* } & 1,40 \\ \text { Alto } & 2,79\end{array} \quad \begin{aligned} & 3,30 \\ & 4,20\end{aligned} \quad \begin{aligned} & 2,35 \\ & 3,49\end{aligned}$

$\mathrm{K}_{2} \mathrm{SO}_{4}$

$\begin{array}{llll}\text { Baixo } & 2,54 & 3,75 & 3,14 \\ \text { Alto } & 2,75 & 3,72 & 3,23\end{array}$

\begin{tabular}{lll}
\hline Mëdias & 3,74
\end{tabular}

FONTE: JONES \& FORD (1972)
* - Al to $N=210 \mathrm{~kg} \mathrm{~N} / \mathrm{ha}$
Baixo $\mathrm{N}=56 \mathrm{~kg} \mathrm{~N} / \mathrm{ha}$
$* *$ Al to $K=155 \mathrm{~kg} \cdot \mathrm{K} / \mathrm{ha}$
Baixo $\mathrm{K}=25 \mathrm{~kg} \mathrm{~K} / \mathrm{ha}$

Tabela 11 - Efeito do incremento dos niveis de $N$ sobre a concentração de oxalato nas partes da plantasde Setaria anceps.

\begin{tabular}{lccc}
\hline Parte da planta & Não adubada $\begin{array}{l}25 \mathrm{~kg} \text { N/ha } \\
\%\end{array}$ & $100 \mathrm{~kg}$ N/ha \\
\hline Lâmina da folha & 4,5 & 4,6 & 4,4 \\
Bainha da folha & 1,6 & 1,8 & 2,9 \\
Hastes & 0,5 & 1,4 & 2,8 \\
\hline
\end{tabular}

FONTE: JONES A FORD (1972) 
$\%$ oxalato

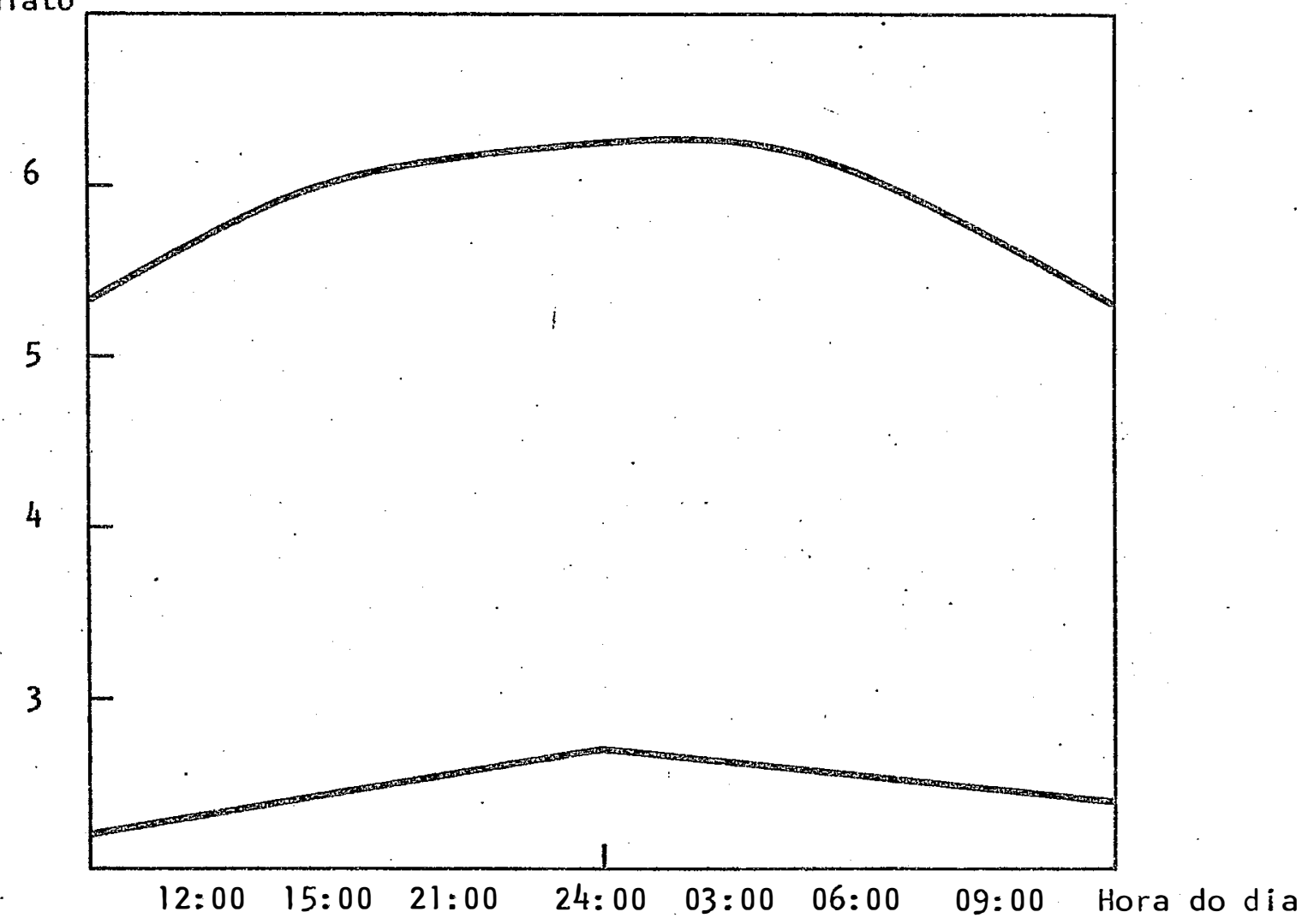

FONTE: JONES Y FORD, 1972

Figura 1 - Variação diurna do conteūdo de oxalato en Setaria anceps cv. Kazungula e Nandi expresso como anhidro de ácido oxálico na matēria seca 
ROUGHAN et alii (1976) estudaram os efeitos da fonte de nitrogênio na acumulação do oxalato em śetaria Kazungula. No primeiro experimento o tratamento com uréia resultou num pequeno e insignificante, decréscimo na concen tração de oxalato comparado com nitrato, baixo potāssio e nitrato mais tratamento de amônio. Contudo, a concentração de oxalato aumentou com a idade da folha e muitas folhas jo vens ainda, continham niveis de oxalato relativamente altos. Os mesmos autores não encontraram variação diurna em oxalato de hastes não floreścentes, nem havia qualquer variação diurna de oxalato em fol has maduras.

$$
\text { GONZALEZ e-COWARD. (1977) determinaram as }
$$

concentrações de oxalatos em Setaria anceps em duas zonas da Costa Rica e sua relação com o intervalo de corte e a fertilização nitrogenada. As porcentagens de ácido oxálico total encontrados variaram de $3,98 \%$ até $7,69 \%$ em ambas as zonas. Encontrou-se um efeito altamente significativo do intervalo de corte sobre a porcentagem de oxalato aumentado de $4,10 \%$ a $6,43 \%$ entre 14 e 35 dias em um local e diminuindo de $7,18 \%$ até $6,33 \%$ no mesmo período em outra zona (Tabela 12). Os mesmos autores não encontraram efeito da fertili zação nitrogenada, entre a interação desta com o intervalo de corte. Entretanto, foi determinada uma alta correlação entre o oxalato solúvel e o oxalato total; $82,30 \%$ do oxalato total foi solúvel. 


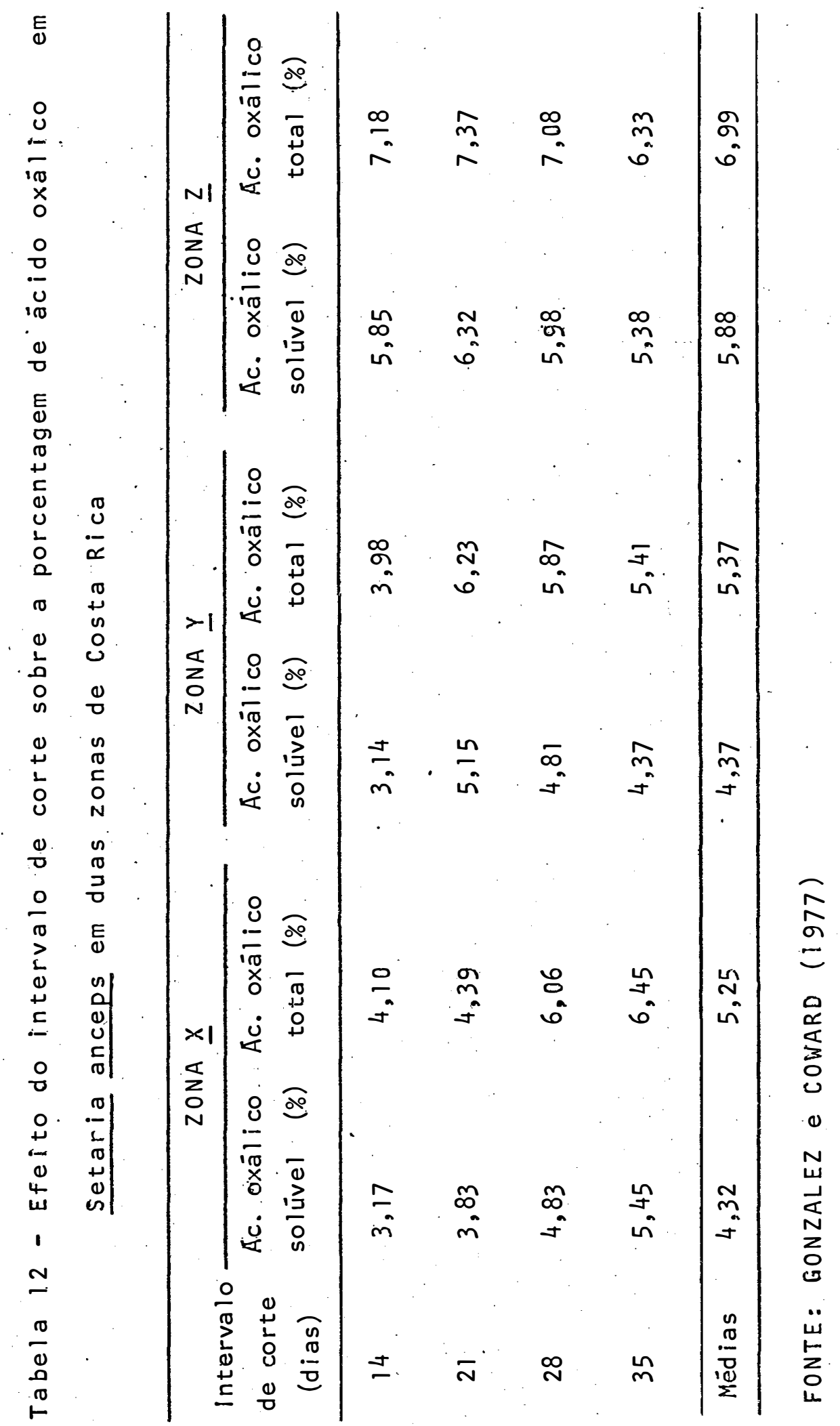


Entretanto; MIDDLETON è BARRY (1978) em um estudo de concentração de oxalato de 5 gramíneas nos trópi cos ümidos de Queensland (Austrälia), encontraram uma corre lação linear e positiva; entre a concentração de oxalato e a concentração de nitrogênio durante o período primavera-ve rão (Figura 2), a concentração de oxalato e a porcentagem de folhas (Figura 3 ), e uma correlação linear e negativa en tre a concentração de oxalato e a taxa de crescimento (Figü ra 4), devido a relação hasite/fol has.

No Brasil, alguns relatos e observações pessoais, em visitas à fazenda indicam a existência do problema. SHENK et alii (1982), em trabalhos realizados no Mato Grosso do Sul, relatam a intoxicação por oxalatos em vacas lactantes em pastagem de setaria. Os animais apresentavam uma queda do cálcio do plasma $(6,7 \mathrm{mg} / 100 \mathrm{ml})$, sendo que o nível normal do Ca no plasma do sangue ë 9 a $11 \mathrm{mg} /$ $100 \mathrm{ml}$. A queda dos niveis de Ca do plasma sanguíneo tem sido atribuída a uma räpida precipitação de cátions deste elemento no organismo animal. Esta precipitação se dá atra vés de absorção dos ânions oxalatos. que atinge a corrente sanguínea, com conseqüente deposição, na forma. de cristais, nos tecidos, notadamente nos rins (Tabela 13).

$$
\text { o efeito do oxalato sobre a disponibilida }
$$

de de cälcio, fósforo e magnésio em bovinos foram estudados por BLANEY et alii (1982). Foi demonstrado que a disponibi- 
\% oxalato.

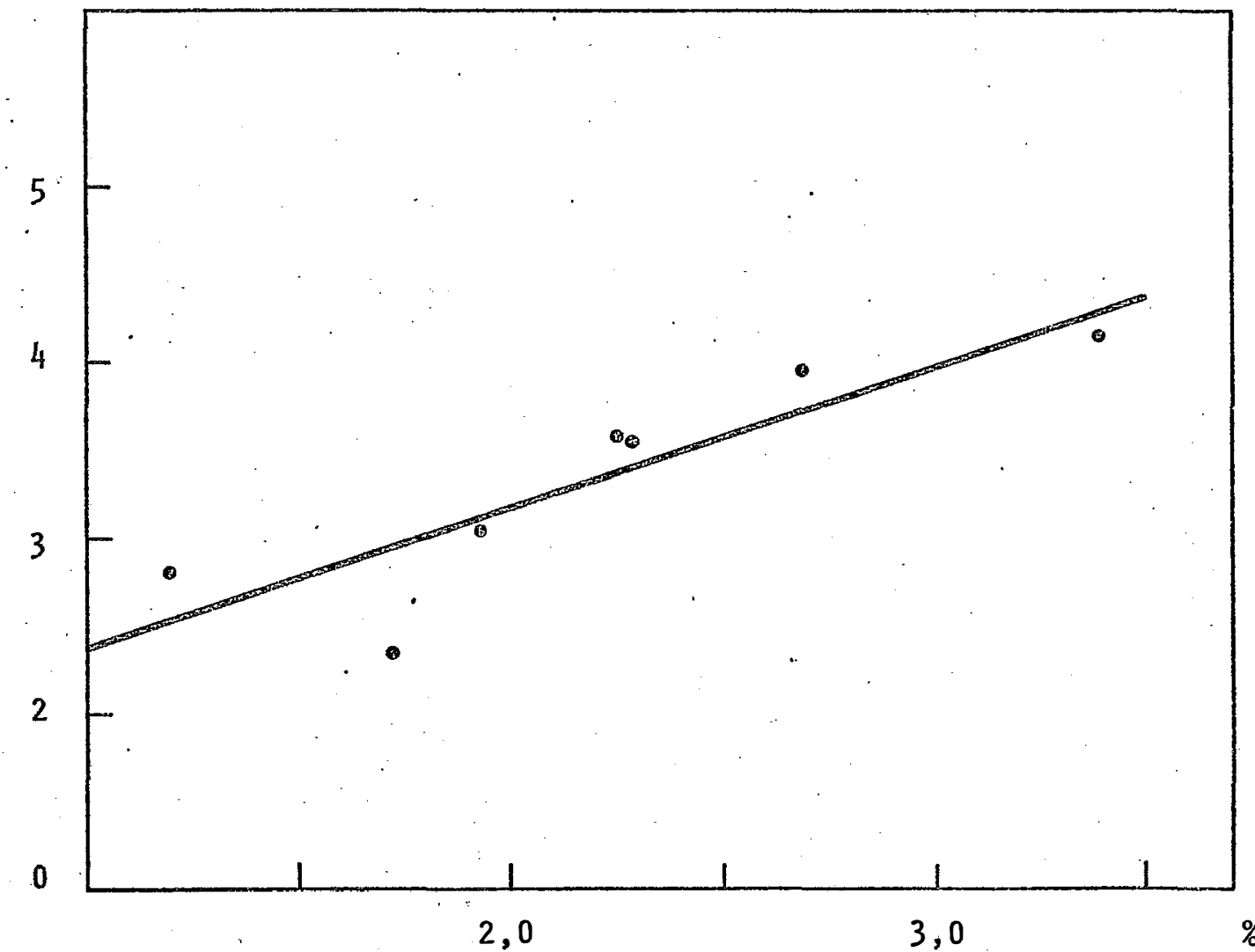

$\gamma=2,56+0,802 x$

$R^{2}=76 \%$

FONTE: MIDDLETON et alii, 1978

Figura 2 - Regressão linear do total de oxalato em folha e caule de Sétaria splendịda colhida hä 3 semanas em relação à concentraçăo de nitrogênio 
$\%$ oxalato

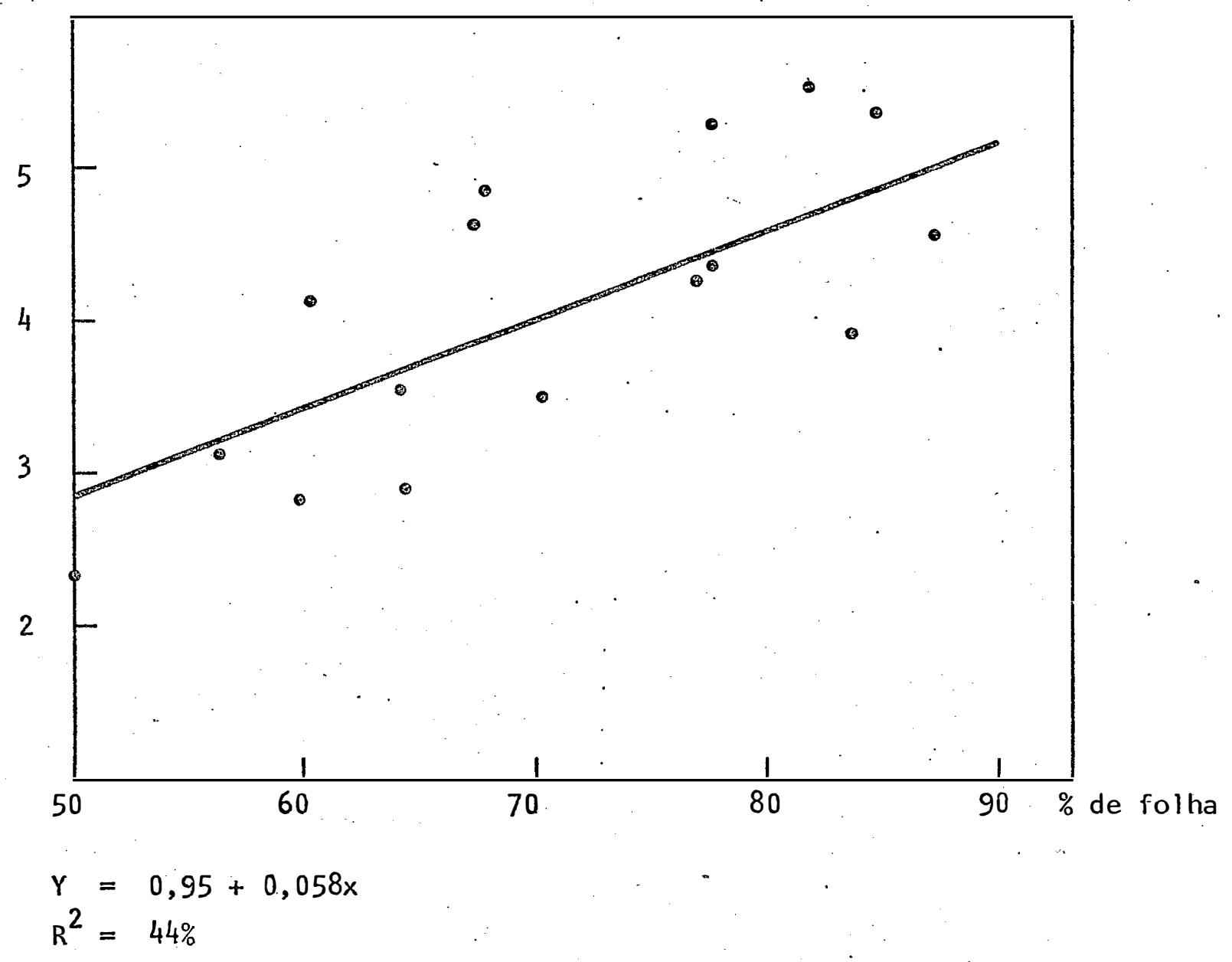

FONTE: MIDDLETON et ali i (1978)

Figura 3 - Regressão linear do total de oxalato em folha e caule de Setaria splendida, colhida a 3 semanas em relação a \% de folha 
$\%$ oxalato

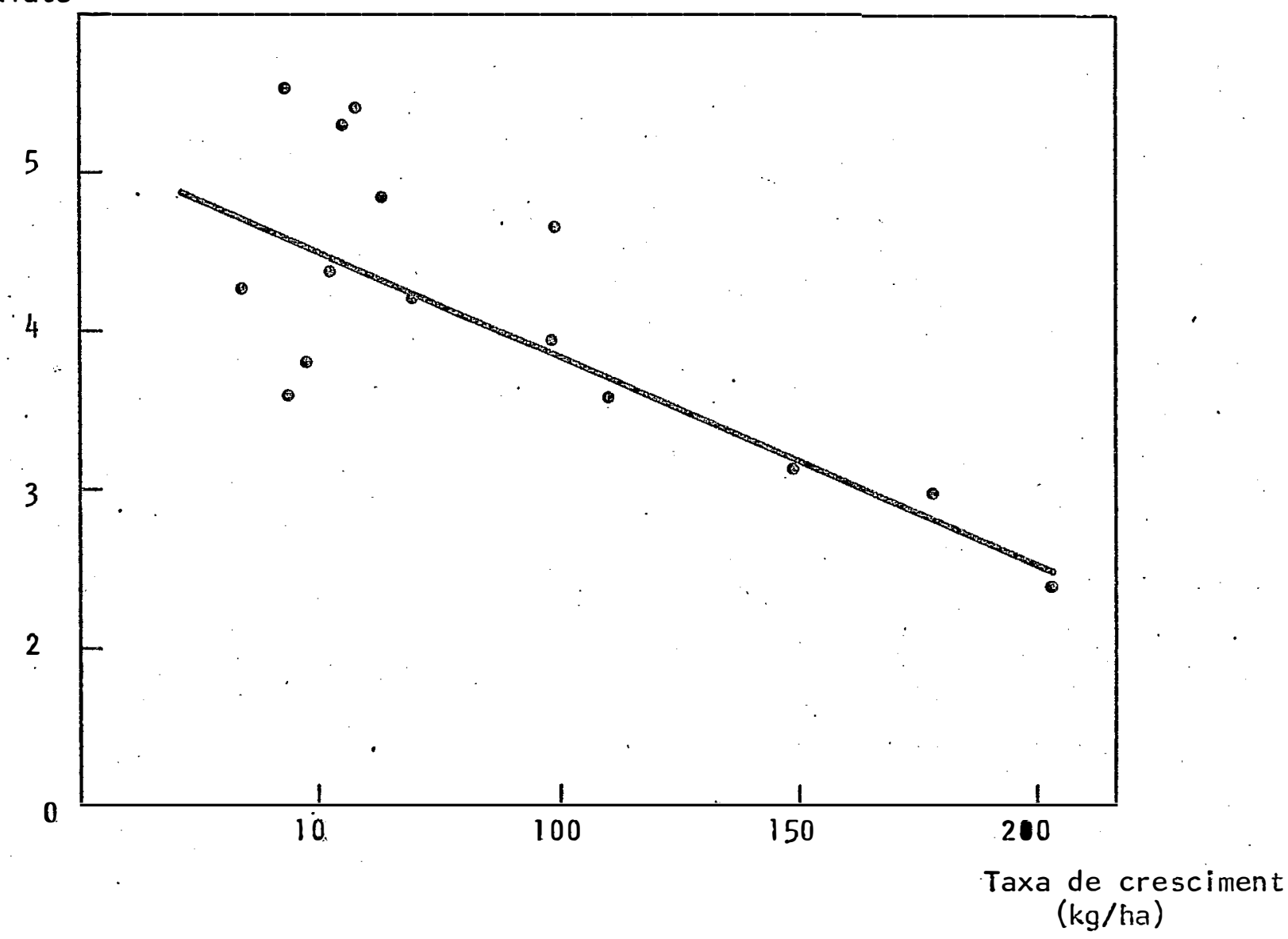

$$
\begin{aligned}
& Y=6,14-0,0.13 x \\
& R^{2}=46 \%
\end{aligned}
$$$$
\text { FONTE: MIDDLETON et alii (1978) }
$$

Figura 4 - Regressão linear do total de oxalato em folha e caule de Setaria splendida colhida a 3 semanas em relação a taxa de crescimento 
Tabela 13 -Níveis de Cälcio (Ca) no plasma.sanguíneo de oito vacas lactantes sadias e oito doentes (suspeito de hipocalcemia)

\begin{tabular}{lllllllllll}
\hline Vacas & \multicolumn{3}{c}{ Níveis de Cálcio no plasma } & $(\mathrm{mg} / 100 \mathrm{ml})$ & & Média \\
\hline Sadias & 9,3 & 8,9 & 8,5 & 8,7 & 6,8 & 7,5 & 9,7 & 9,3 & 8,6 \\
Doentes & 7,0 & 6,7 & 7,0 & 8,2 & 5,1 & 5,5 & 7,0 & 6,7 & 6,7 \\
\hline
\end{tabular}

Padrão normal de $\mathrm{Ca}=9$ a $11 \mathrm{mg} / 100 \mathrm{ml}$.

FONTE: SHENK et alii (1982).

lidade do Mg e P dos capins tropicais ë satisfatōria para os ovinos, entretanto, a disponibilidade do Ca é diminuída em mais de $20 \%$ por causa dos cristais de oxalato de cálcio nos. capins que não. säo utilizados pelos bovinos. A disponibilidade máxima de Cáneste capim atingia cerca de $50 \%$ que é absorvida pelos bovinos.

os ruminantes podem dégradar os oxalatos so lüveis no rümen, e esta degradação é facilitada pela adaptă ção da microflora ruminal nos alimentos na concentração de oxalatos (BLANEY et alii, 1981 b).

Em relação aos eqüinos, segundo HINTZ (1983), nos ültimos anos pesquisa mundial tem demonstrado grande preocupação no metabolismo do cālcio. Assim, Mc KENZIE e SCHULTZ (1983) relatam que os cavalos que pastejam em setaria podem desenvolver uma deficiência de cālcio induzida, denominada hiperparatiroidismo nutricional secundärio. Den-- 
tre os sinais apresentados, cita, relutância em mover-se inchaço bilateral dos maxilares superiores e inferiores, alēm de perda de cálcio do esqueleto.

WALTHALL e MC KENZIE (1976) relatam acorrência de sintomas de osteodistrofia fibrosa em eqúídeos pastan do diversas espēcies forrageiras em Queensland-Austrälia. Co mo tal moléstia geralmente ocorre, quando os aninais ingerem alimentos cuja relação cālcio/fósforo esteja em níveis infe riores a 0,8 : 1 associaram-se a um desbalanço mineral das próprias forrageiras. Entretanto, como mostra a Tabela 14, a causa de tal enfermidade não foi o desbalanço mencionado, mas sim, a presença de teores elevados de oxalato.

Segundo Tosi, citado por PUPO (1984) as recentes observaçōes effetuadas na região de Bauru, em São Paulo, dão conta que eqüinos criados em pastagens de Brachiaria humidicola apresentaram a enfermidade vulgarmente chamada de "cara inchada", traduzida cientificamente por doença carencial que afeta principalmente a animais jovens, mas que pode, tambēm, surgir nos adultos, determinado por uma alimen tação deficiente em cálcio e fósforo e insuficiente em vitamina D. Relata, ainda, que o sintoma principal dessa enfermi dade é a alteração sofrida na cabeça, com o crescimento anor mal dos ossos do maxilar, nasal, lacrimal e mandíbula, cujo tecido ósseo apresenta-se rarefeito, com pequena resistência, devido a quase ausência de cálcio, substituídas por tubērcu- 


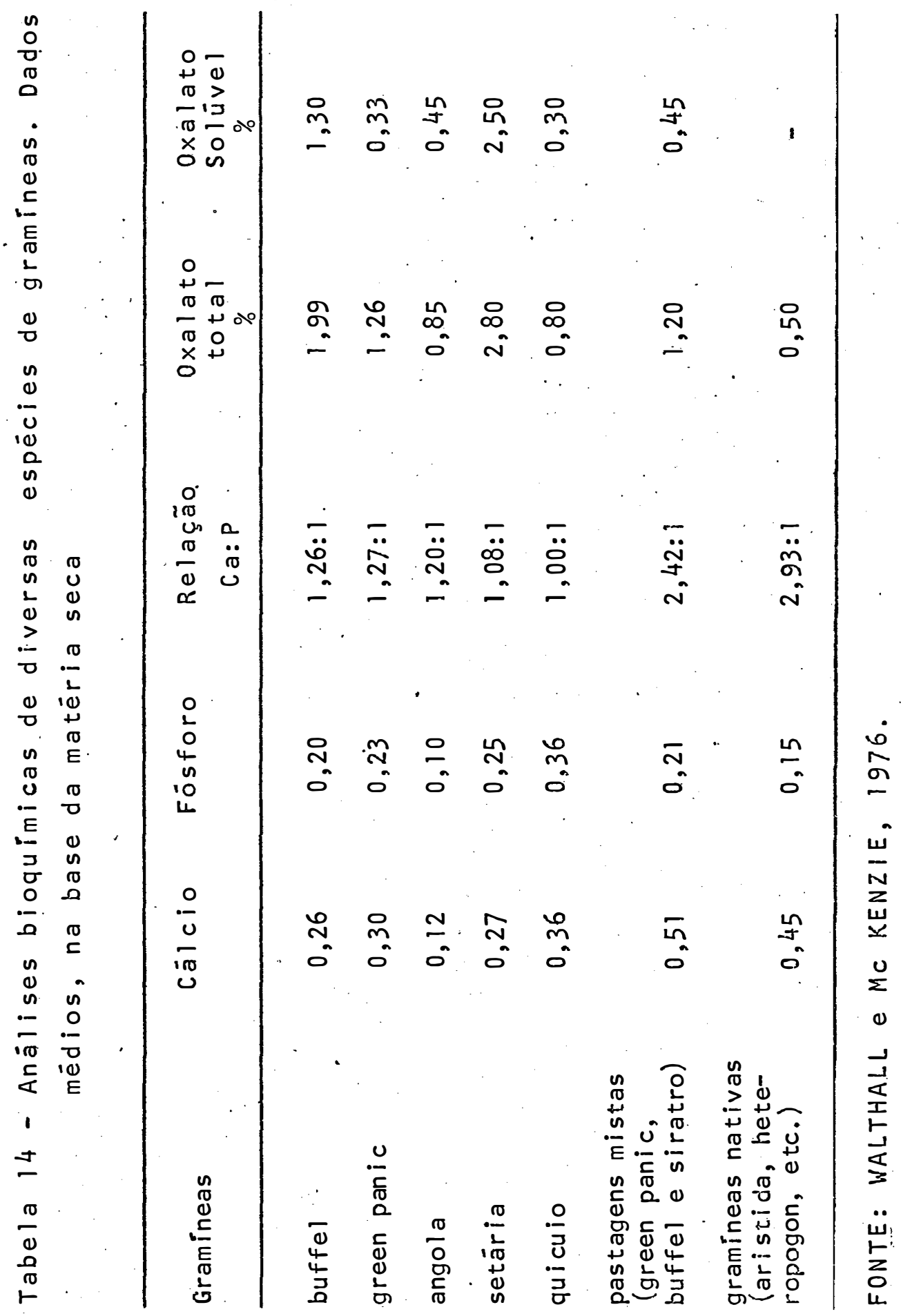


los fibrosos e cartilaginosos, construída pelos organismos para suprir a falta do material, e que não possuem a mesma resistênclia do materíal original. 


\section{Material e Mlétodos}

\subsection{Material}

3.1.1. Local

o experimento foi conduzido em casa de vegetaçäo do Departamento de Agricultura e Horticultura, da Escola Superior de Agricultura "Luiz de Queiröz", em Piracicaba-SP., no período de março a julho de 1985.

\subsubsection{Solo e Espécie Vegetal}

$$
\text { o solo utilizado amostrado a uma profundidade }
$$

de 0-20 cm, è uma areia quartzosa de ocorrência no Município de Piracicaba identificado como orthic quartzipsamment (FRANÇA, 1985, Comunicação Pessoal) e classificado por RANZANI et alii (1966), como série Ribeirão Claro.

$$
\text { As anălises químicas do mesmo são apresentadas }
$$

na Tabela 15. 
Tabela 15 - Principais características químicas de amostras do solo

\begin{tabular}{|c|c|c|c|c|c|c|c|c|c|c|c|}
\hline \multicolumn{2}{|c|}{$\mathrm{pH}$} & \multirow{2}{*}{$\begin{array}{l}\% \\
\text { C. }\end{array}$} & \multirow{2}{*}{$\begin{array}{c}\mathrm{ppm} \\
\mathbf{P}\end{array}$} & \multicolumn{7}{|c|}{$\mathrm{meq} / 100 \mathrm{ml}$} & \multirow{2}{*}{$\begin{array}{r}\% \\
V\end{array}$} \\
\hline $\mathrm{CaCl}_{2}$ & $\mathrm{H}_{2} \mathrm{O}$ & & & $\mathrm{K}$ & $\mathrm{Ca}$ & $\mathrm{Mg}$ & Al & $H$ & $S$ & CTC & \\
\hline 4,2 & 4,7 & $0 ; 2$ & 2,0 & $0,0.2$ & 0,4 & 0,1 & 0,5 & 1,7 & 0,5 & 2,7 & 19,1 \\
\hline
\end{tabular}

Obtilda de acordo com a metodologia descrita em RAlJ e QUAGGIO (1983).

\subsubsection{Material Corretivo}

Foi utilizado o calcário dolomítico calcinado cuja anālise revelou as seguintes características físico-quí micas, representadas na Tabela 16.

Tabela 16. Principais características físico-químicas de amostra do corretivo

\begin{tabular}{|c|c|c|}
\hline Determinação & Anälise & $\begin{array}{c}\text { Resultado } \\
\%\end{array}$ \\
\hline oxido de cälcio & $\mathrm{CaO}$ & 20,31 \\
\hline Oxido de Magnēsio & $\mathrm{MgO}$ & 19,02 \\
\hline Carbonato de Cälcio & $\mathrm{CaCO}_{3}$ & 36,35 \\
\hline Carbonato de Magnēsio & $\mathrm{MgCO}_{3}$ & 39,94 \\
\hline PRNT & & 57,30 \\
\hline PN & & 86,78 \\
\hline Silica e insolüveis & Cálcio & - \\
\hline Solubilidade em EDTA & Magnēsio & - \\
\hline Sólubilidade em EDTA. & $\cdot$ & \\
\hline
\end{tabular}




\begin{tabular}{|c|c|c|c|c|}
\hline \multirow[t]{5}{*}{ Granulometria } & ASTM & Tyler & Abertura & \\
\hline & USS & Mesh & $(\mathrm{mm})$ & \\
\hline & 8 & 8 & 2,380 & 99,96 \\
\hline & 10 & 10 & 2,000 & 99,51 \\
\hline & 20 & 20 & 0,840 & 86,43 \\
\hline & 30 & 28 & 0,590 & 75,56 \\
\hline & 50 & 48 & 0,297 & 56,65 \\
\hline & 60 & 60 & 0,250 & 51,35 \\
\hline$\cdot$ & 70 & 65 & 0,210 & 47,41 \\
\hline & 100 & 100 & 0,149 & 40,11 \\
\hline
\end{tabular}

A calagem foi baseada para elevar a saturação de bases (V) da capacidade de troca de cātions (CTC) do solo a valores.de acordo com a necessidade do capim setaria, segundo a seguinte förmula:

$\underset{(\text { em } t / h a)}{\text { Necessidade de calagem }}=\frac{\left(V_{2}-V\right)}{100} T \times$ fator de calagem

onde, $V_{2}=$ saturação em base necessāria para a planta forra: geira a ser. plantada

$V_{1}=$ saturação em base que. o solo apresenta antes de sofrer calagem

$T=$ capacidade de troca de cátions do solo

$\begin{aligned} & \text { Fator de } \\ & \text { calagem }\end{aligned}=$ fator de correção $100 / P R N T$ do material corretivo.

\subsubsection{Fonte de Nutrientes}

Os macronutrientes Nitrogênio, Fösforo e Potässio foram forneciơos, respectivamente, na forma de uréia $(43 \% N)$, superfosfato triplo $\left(42 \% \mathrm{P}_{2}{ }^{0}{ }_{5}\right)$ e cloreto de potássio. 
$\left(60 \% \mathrm{k}_{2} 0\right)$. $0 \mathrm{~s}$ micronutrientes boro, ferro, manganês, zinco, cobre e molibdenio foram fornecidos, respectivamente, nas formas de $\mathrm{H}_{3} \mathrm{BO}_{3}$, $\mathrm{FeSO}_{4} \cdot 7 \mathrm{H}_{2} \mathrm{O}, \mathrm{MnSO}_{4} \cdot \mathrm{H}_{2} \mathrm{O}, \mathrm{CuSO}_{4} \cdot 5 \mathrm{H}_{2} \mathrm{O}$ e $\mathrm{NaMOO}_{4}$. $4 \mathrm{H}_{2} \mathrm{O}$. Cálcio e magnésio foram fornecidos via calagem.

\subsubsection{Recipientes}

Utilizaram-se vasos de terra com capacidade pạ ra $5 \mathrm{~kg}$ de TFSA, pintados internamente com uma tinta impermea bilizante "Neutrol"; tendo na'parte inferior um orificio para escoamento de ăgua e solução de nutrientes, os quais eram recolhidos em pratos de barro.

\subsection{Métodos}

a) Coleta e preparo das amostras de terra

Foram retiradas amostras de terra do solo, jä citado, na profundidade de $0-20 \mathrm{~cm}$, as quais depois de destorroadas foram postas a. secar ao ar, passadas em peneira com malha de $2 \mathrm{~mm}$ e uniformizadas por misturas sucessivas de porçoes.

b) Incubação das amostras com calçärio

De posse da anālise química do solo e do material corretivo foi determinada a necessidade de calagem visando elevar a saturação de base a $40 \%$, valor exigido pelo capim setaria segundo WERNER (1984). A quantidade de calcärio determinada foi equivalente a $0,959 \mathrm{t} / \mathrm{ha}$. 
Assim, foram tomadas aproximadamente 400 kg de TFSA esparramados uniformemente sobre uma lona plást ca, aplicando o calcário e muito bem homogeneizado. Seguida mente, adicionaram-se 10 litros de àgua destilada para cada $100 \mathrm{~kg}$ de TFSA, deixando-se o solo assim incubado por um período aproximado: de 30 dias. Durante esse período proce deu-se a um revolvimento constante dos solos, bem como, a uma reposição de umidade a cada 3 dias.

\section{c) Tratamentos}

os tratamentos, cinco níveis de nitrogênio $(N)$, três níveis de potássio (K) e quatro repetições, foram montados num delineamento inteiramente casualizado com esquema fatorial $(5 \times 3)$, conforme dados da Tabela 17 .

d) Instalação do ensaio d. 1. Adubação básica dos vasos Apōs a pesagem de $5 \mathrm{~kg}$ de TFSA, procedeu se a uma adubação básica do mesmo, sendo que as soluçōes de micronutrientes foram baseadas em HOAGLAND e ARNON (1950), conforme dados da Tabela 18 .

\section{d.2. Nitrogênio (N)}

o nitrogênio foi fornecido como uma solução de urēia em ägua (12 g urēia/litro), nas doses jä enumera das na Tabela 17 , sendo que os tratamentos correspondentes 


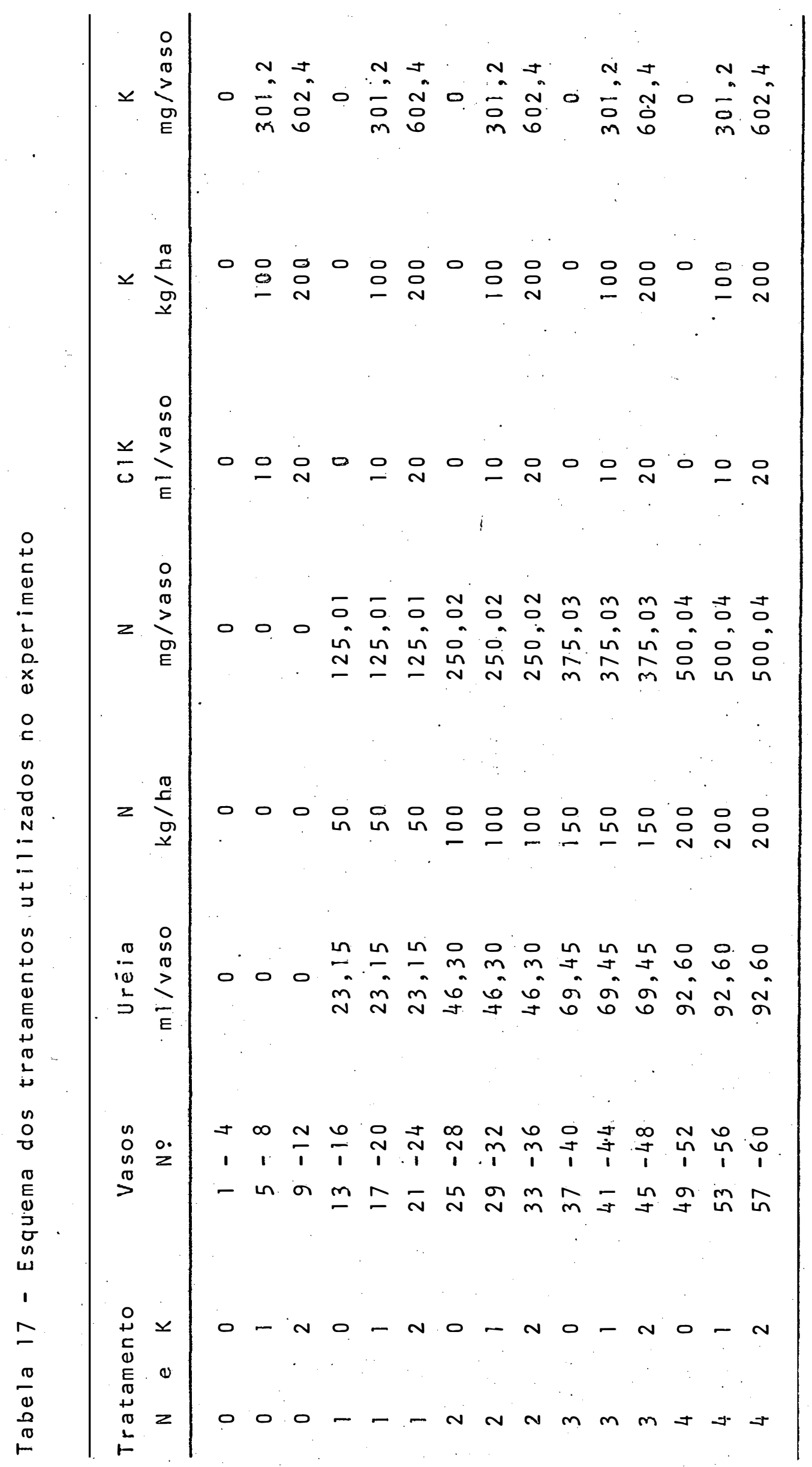




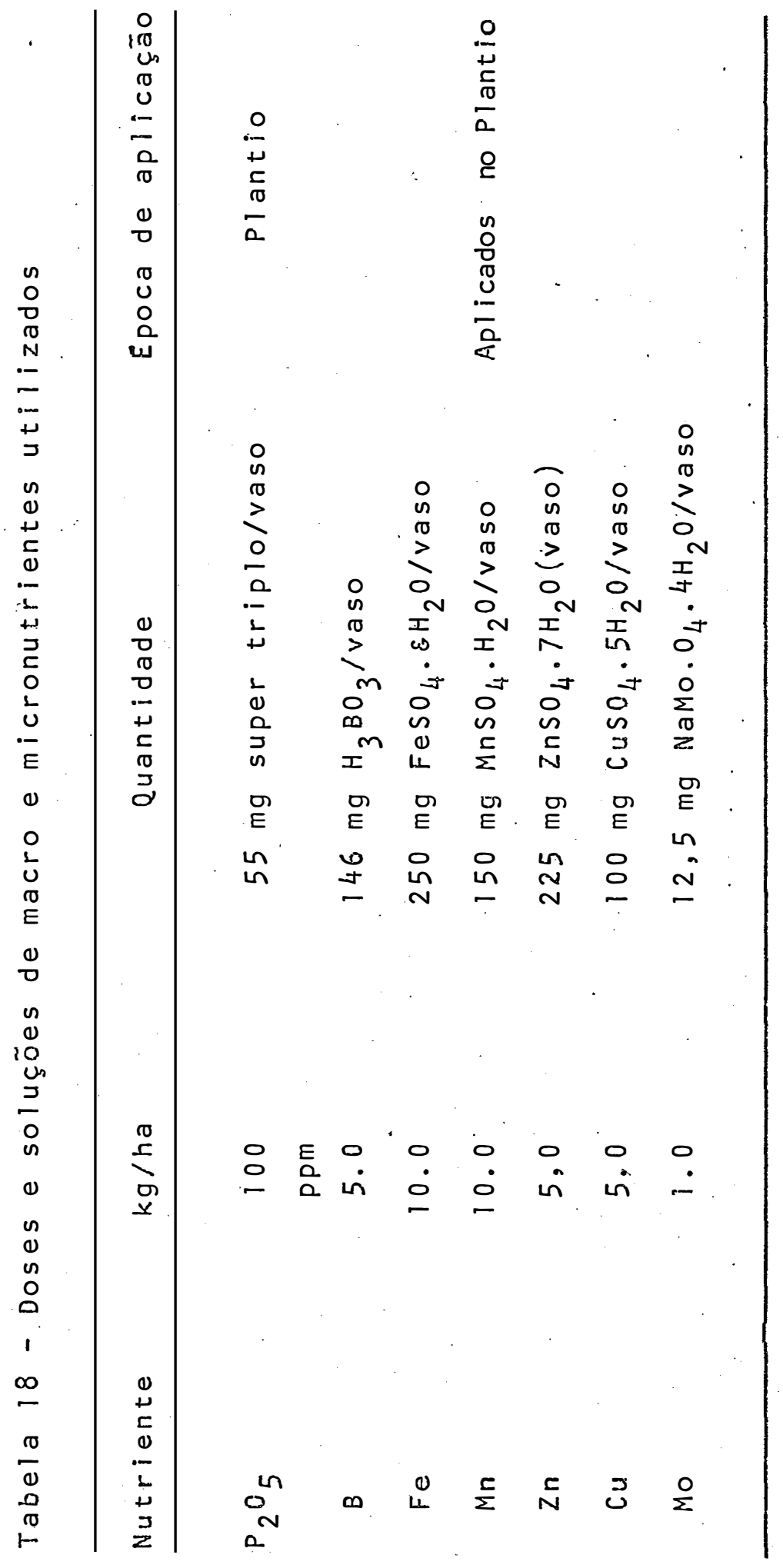


ao nivel 2 de nitrogēnio $(50 \mathrm{~kg} \mathrm{~N} / \mathrm{ha})$ foi aplicado no iní cio do tratamento e em uma só dose. Já os tratamentos com nîvel 3,4 e 5 de nitrogênio $(i 00,150$ e $200 \mathrm{~kg} \mathrm{~N} / \mathrm{ha})$ foram aplicados em duas doses iguais, uma no início do tratamento e outra 10 dias após.

\section{d.3. Potāssio (K)}

0 potássio foi fornecido como uma solução de cloreto de potássio (KCl) em āgua $(50 \mathrm{~g} \mathrm{KCl}) / \ell$ ), em uma só aplicação, no início do tratamento, em dose já enumerada na Tabela 17 .

\section{d. 4. Semeadura e desbaste}

Apōs a adição de água destilada nos vasos, de modo a elevar a umidade do solo acerca de $2 / 3$ da capacidade de campo, foi realizada a semeadura, sendo utilizadas 20 sementes por vaso. Tal quantidade foi utilizada, devido ao resultado obtido na análise laboratorial apresentando um valor cultural de $48,3 \%$. As sementes foram colocadas a $1,0 \mathrm{~cm}$ de profundidade, a seguir, coberta com o mesm• solo.

Dez dias após a semeadura, foi feita o desbaste em todos os vasos do experimento, deixando-se quatro plantas o mais uniforme possivel no que diz respeito a altura e nümero de folhas. 
e) Regas

Duas ou três vezes por semana, foram pesados ao acaso, alguns vasos, e restituído o peso de ägua evaporada, tirando uma média que se aplicou a todos os vasos.

A medida que as plantas foram crescendo, a quantidade de ägua adicionada aumentou. Estimou-se a quantidade requerida pela observação do grau de umidade do solo e a aparência das plantas. 0 excesso de ägua que percolou para o coletor foi devolvido ao interior do vaso.

\section{f) Coleta}

0 corte da gramínea foi efetivada aos 35 dias após a ceifa de uniformização, cortando-se as plantas ao nivel do colo. 0 material colhido, foi secado em estufa a $70^{\circ} \mathrm{C}$ até obter um peso constante.

\section{- Após a secagem, as amostras eram expostas} ao ambiente para o equilibrio com a umidade relativa do ar; em seguida, eram pesadas, a fim de avaliar a produção de mä̈ëria seca por vaso, moíldas em moinho modelo "Willey" e guardados em vidros ber fechados.

g) Anālises químicas da planta

o nitrogênio total da parte aêrea foi deter 
minado pelo método semimicro-kjeldahl, descrito por SARRUGE e HAAG (1974), o potāssio por espectrometria de :absorção atômica (ZAGATTO et aliii, 1981), o cālcio e magnésio foram determinados seguindo-se a técnica de espectrofotometria de absorção atômica (SARRUGE e HAAG, 197.4) e o àcido oxālico segundo a metodologia descrita por MolR (1953).

\section{h) Anālises Estatísticas}

As variáveís estudadas: produção de matéria seca/vaso, conteúdo de ácido oxálico, nitrogênio, potássio, cálcio e magnésio foram submetidas à análises de variancia, em um delineamento experimental inteiramente ao acaso e com um esquema fatorial $5 \times 3$, com quatro repetições (Tabela 19). Tabela 19 - Esquema de anālises de variância

\begin{tabular}{lc}
\hline Causa da variação & G.L. \\
\hline Nitrogênio (N) & 4 \\
Potāssio (K) & 2 \\
Interação $(N \times K)$ & 8 \\
Residuo & 45 \\
\hline Total & 59 \\
\hline
\end{tabular}

Para os niveis de fatores estudados efetuam se também uma anālise de regressão polinomial; e as equações obtidas são apresentadas graficamente em resultados e discussão. 


\section{Resultados e Discussão}

\subsection{Efeito de Doses de Nitrogênio e Potāssio na produção de Matēria Seca}

Na Tabela 1 (Apênọice) são apresentadas as produções de matéria seca da parte aérea do capim setaria, a $70^{\circ} \mathrm{C}$, obtidas pela aplicação de doses de nitrogênio e potássio, enquanto que … Tabela 20 , as médias destes parâme tros e a anālise da variância.

$$
\text { os resultados da análise da variância para }
$$

a variāvel produção mostrou um efeito significativo para nitrogênio e potássio e a interação nitrogênio versus potássio (Tabela 20 ). Do estudo da regressão polinomial para os niveis de nitrogênio, selecionou-se a equação polinomial de segundo grau (Figura 5 ).

A equação quadrática sugere que foi ating da a maior produção para esta forrageira. Assim, a matéria 
Tabèla 20 - Mëdias geraís da produção de matēria seca a $70^{\circ} \mathrm{C}$, da parte aérea das plantas ( $g / v a s o$ ) em função dos níveis de $\mathrm{N}$ e $\mathrm{K}$ e o quadro da anālise da variância

\begin{tabular}{|c|c|c|c|c|c|c|}
\hline \multirow{2}{*}{ Niveis de K } & \multicolumn{5}{|c|}{ Niveis de N } & \multirow{2}{*}{$\begin{array}{c}\text { Médias } \\
\text { gerais } \\
\text { dos } \\
\text { niveis de K } \\
\end{array}$} \\
\hline & $\mathrm{N}_{0}$ & $\mathrm{~N}_{1}$ & $\mathrm{~N}_{2}$ & $\mathrm{~N}_{3}$ & $N_{4}$ & \\
\hline $\mathrm{K}_{0}$ & 1,40 & 3,27 & 4,15 & 6,25 & 6,27 & 4,26 \\
\hline$k_{1}$ & 1,47 & 4,97 & 6,12 & 6,67 & 8,20 & 5,48 \\
\hline$k_{2}$ & 1,87 & 5,37 & 7,20 & 7,40 & 9,17 & 6,20 \\
\hline $\begin{array}{l}\text { Mëdias gerais } \\
\text { dos niveis de }\end{array}$ & 1,58 & 4,53 & 5,82 & 6,77 & 7,88 & \\
\hline
\end{tabular}

ANALLISE DE VARIANNCIA

\begin{tabular}{lrrrrr}
\hline Causas da variação & G.L. & S.Q. & Q.M. & F & Prob. $>$ F \\
\hline Nitrogênio & 4 & 282,6544338 & 70,6636085 & 133,3001 & 0,00001 \\
Potássio & 2 & 39,1840785 & 19,5920392 & 36,9585 & 0,00001 \\
Nit. x Pot. & 8 & 11,9725846 & 1,4965731 & 2,8231 & $0,01.259$ \\
Resíduo & 45 & 23,8549067 & 0,5301090 & & \\
\hline Total & 59 & 357,6660035 & & & \\
\hline
\end{tabular}

Mëdia Geral $=5,330000$

C.V. $=14,660 \%$ 
MS g/vaso

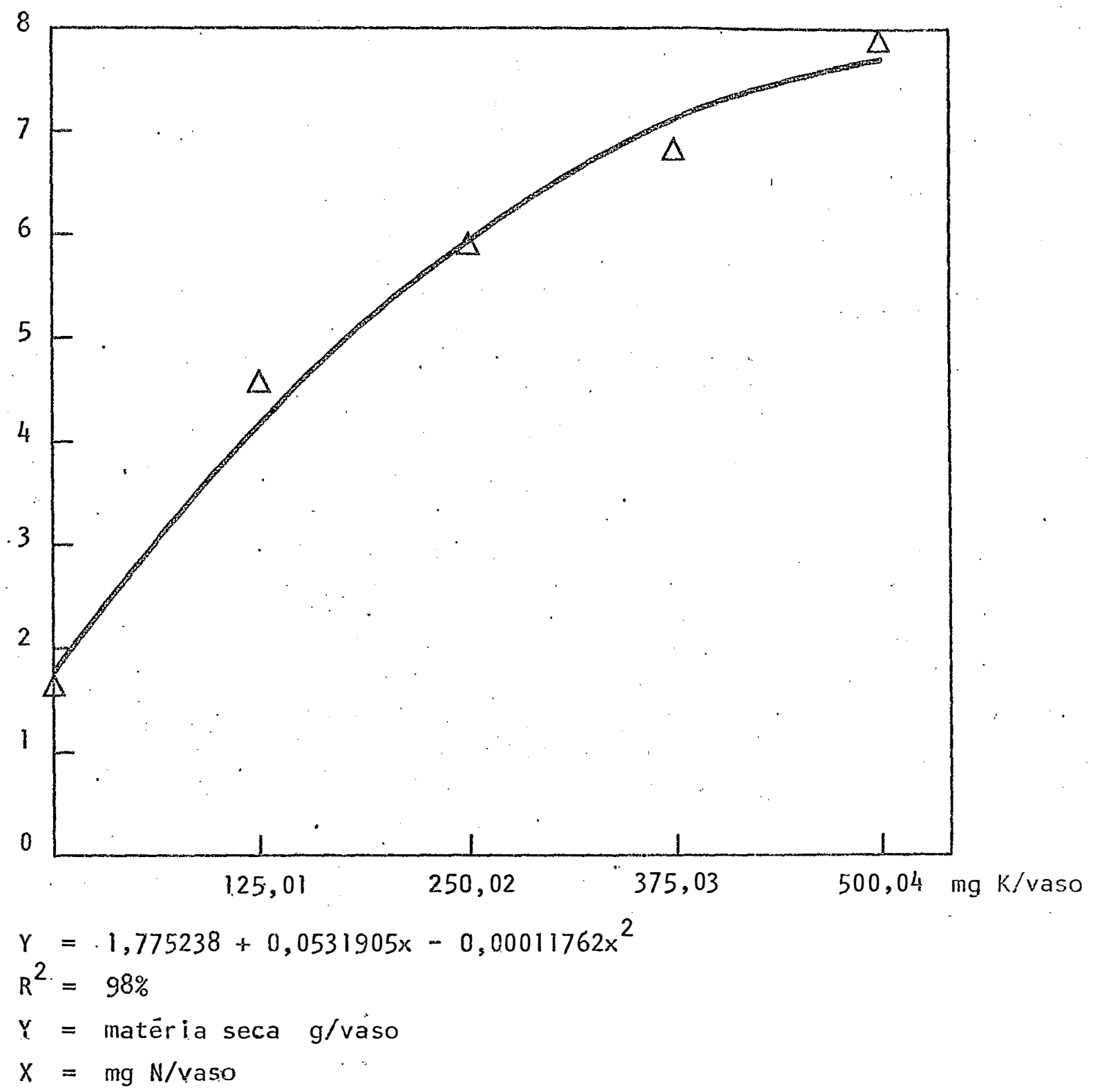

Figura 5 - Éfeito de doses de $N$ na produção de matéria seca (g/vaso) da parte aérea do capín setäría 
seca produzida pelonivel $N_{0}(0 \mathrm{~kg} \mathrm{~N} / \mathrm{ha}), N_{1}(50 \mathrm{~kg} / \mathrm{ha}), N_{2}$ $(100 \mathrm{~kg} / \mathrm{ha}), N_{3}(150 \mathrm{~kg} / \mathrm{ha})$ e $N_{4}(200 \mathrm{~kg} / \mathrm{ha})$ foram 1,58, $4,53,5,82,6,77$ e 7,88 gramas/vasos, respectivamente. № ta-se que, para a forrageira em estudo o aumento na dose de nitrogênio proporciona um aumento de produção até um determinado limite.

Com relação ao nitrogênio, MALHERBE (1969), HACKER E JONES (1969), BOGDAN (1977) e OLSEN (1982) citaram que a adubação nitrogenada $e_{i}$ o fator que mais interfere na produção e qualidade da planta forrageira. OLSEN (1982) encontrou uma resposta linear da produção de matéria secá no capim setaria até um nível de fertili zação nitrogenada considerada alta $(448 \mathrm{~kg} / \mathrm{ha}$ de $\mathrm{N})$ e com um leve. acrēscimo até os $896 \mathrm{~kg} / \mathrm{ha}$ de $\mathrm{N}$.

Para a aplicação de potāssio, verificicou - se um efeito linear e positivo sobre a produção de matéria seca (Figura 6 ). Assim, o nivel $k_{0}(0 \mathrm{~kg} / \mathrm{ha}$ de $\mathrm{K})$, $\mathrm{K}_{1}$ $(100 \mathrm{~kg} / \mathrm{ha}$ de $\mathrm{K})$ e $K_{2}(200 \mathrm{~kg} / \mathrm{ha}$ de $\mathrm{K})$ foram $4,26,5,48$ e 6,20 gramas/vasos, respectivamente.

A regressão linear positiva sugere que as respostas da forrageira em estudo por cada quilograma de po tāssio aplicado corresponde a um acrēscimo de 0,0098\% na produção de matéria seca.

Respostas positivas a aplicação de potássio 
MS g/vaso

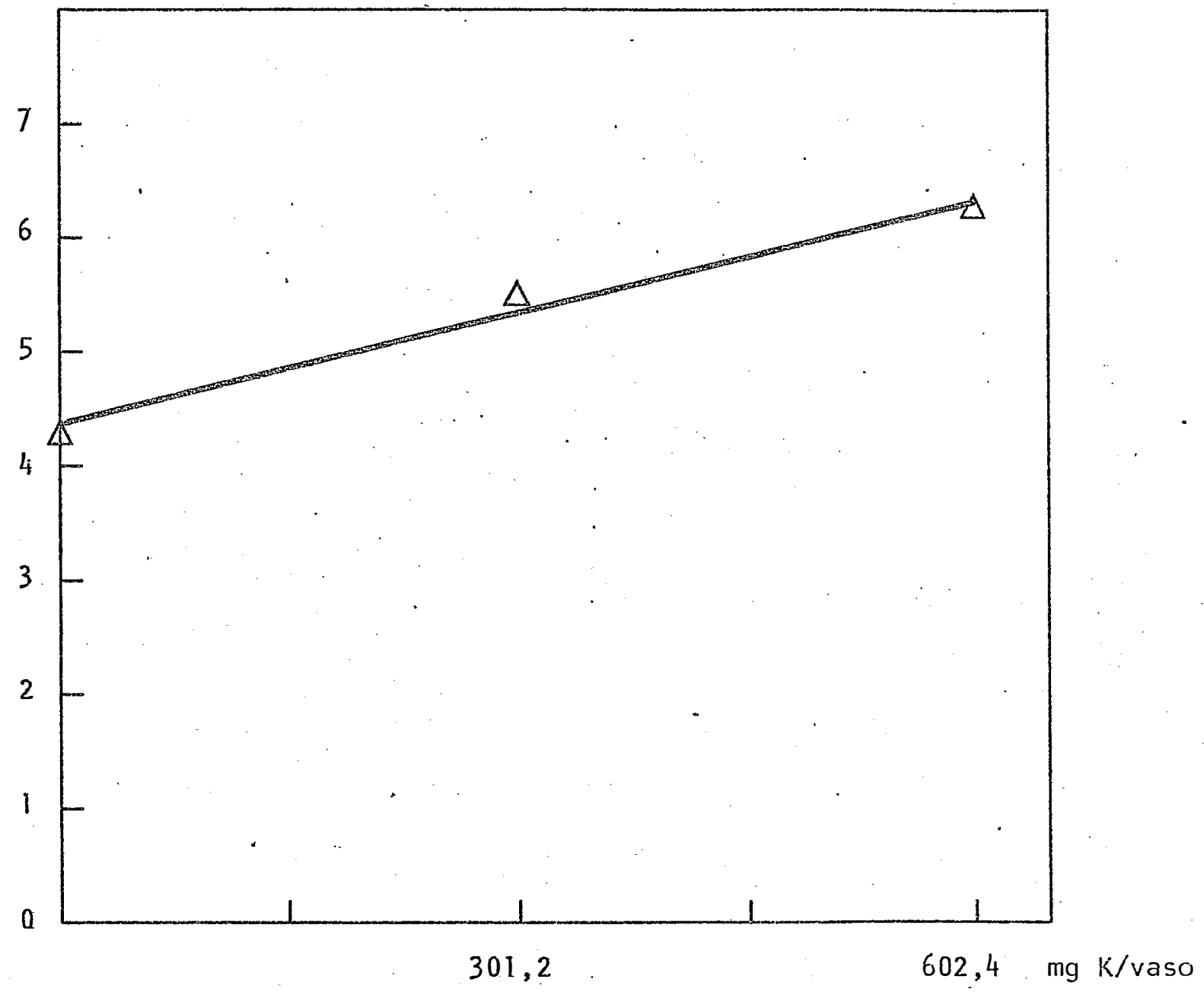

$Y=4,35+0,0098 x$

$R^{2}=98 \%$

$\gamma=$ matēria seca $\mathrm{g} / \mathrm{vaso}$

$X=m g k / v a s o$

Figura 6 - Efeito da dose de K na produção de matēria seca (g/vaso) da parte aérea do capim setäria 
foram encontrados tambēm por HACKER e JONES (1969) e BOGDAN (1977). Por outro lado, verificou-se também uma interação significativa de nitrogênio versus potāssio (Tabela 20). As sim, nota-se o efeito da adiçãa de potássio sobre a produção de matéría seca, somente onde houve adição de fertilizante nitrogenado, fato este também observado por HACKER e JONES (1969) e LUCK (1979), os quais verificaram não haver respostas significativas. quando o potássico era o único elemento aplicado.

\subsection{Efeito dos Tratamentos sobre a concentraçäo de} Oxalato na Parte Aérea

Na Tabela 02 (A.pêndice) são apresentadas as concentrações de oxalato em porcentagem de matéria seca a $70^{\circ} \mathrm{C}$. As médias gerais desse parâmetro, bem como, a análise da variância, são apresentados na. Tabela 21 .

Os resultados da anālise da variancia para a variāvel oxalató mostrou um efeito significativo para potássio e para a interação nitrogênio versus potässio (Tabela 21 ), indicando a ação de nitrogênio afetando os resultados de potássio sobre oxalato. Esse resultado explica que o nitrogê nio não interfere diretamente na concentração de oxalato, mas sim no efeito de potássio sobre o oxalato, ou seja, o efeito do nitrogênio sobre oxalato é indireto.

Do estudo da regressão polinomial para os ní- 
Tabela 21 - Médias gerais da concentração de äcido oxălico, em \%, na parte aérea das plantas em função dos níveis de $\mathrm{N}$ e $\mathrm{K}$ e $\mathrm{o}$ quadro de anālise de variância (Média de 4 repetições)

\begin{tabular}{|c|c|c|c|c|c|c|}
\hline \multirow{2}{*}{ Niveis de K } & \multicolumn{5}{|c|}{ Niveis de $N$} & \multirow{2}{*}{$\begin{array}{c}\text { Mëdias } \\
\text { gerais dos } \\
\text { niveis de } \\
\text { K }\end{array}$} \\
\hline & $\mathrm{N}_{0}$ & $\mathrm{~N}_{1}$ & $\mathrm{~N}_{2}$ & $\mathrm{~N}_{3}$ & $N_{4}$ & \\
\hline $\mathrm{K}_{0}$ & 4,07 & 4,18 & 4,75 & 4,55 & 5,02 & 4,51 \\
\hline $\mathrm{k}_{1}$ & 5,60 & 4,71 & 4,51 & 4,60 & 5,44 & 4,97 \\
\hline $\mathrm{K}_{2}$ & 5,89 & 5,75 & 5,06 & 5,69 & 4,88 & 5,45 \\
\hline $\begin{array}{l}\text { Medias gerai } \\
\text { dos'niveis d }\end{array}$ & 5,18 & 4,88 & 4,77 & 4,94 & 5,11 & \\
\hline
\end{tabular}

ANALLISE DE VARIÃNCIA

\begin{tabular}{lccccc}
\hline Causas da variação & G.L. & S.Q. & Q.M. & F & Prob.>F \\
\hline Nitrogênio & 4 & 1,3428457 & 0,3357114 & 1,8198 & 0,14074 \\
Potässio & 2 & 8,8462068 & 4,4231034 & 23,9762 & 0,00001 \\
Nit. x Pot. & 8 & 8,4864923 & 1,0600115 & 5,7503 & 0,00013 \\
Resíduo & 45 & 8,3015486 & 0,1844789 & & \\
\hline Total & 59 & 26,9770934 & & & \\
\hline
\end{tabular}

Média geral $=4,985330$

C.V. $\%=8,615 \%$ 
\% oxalato

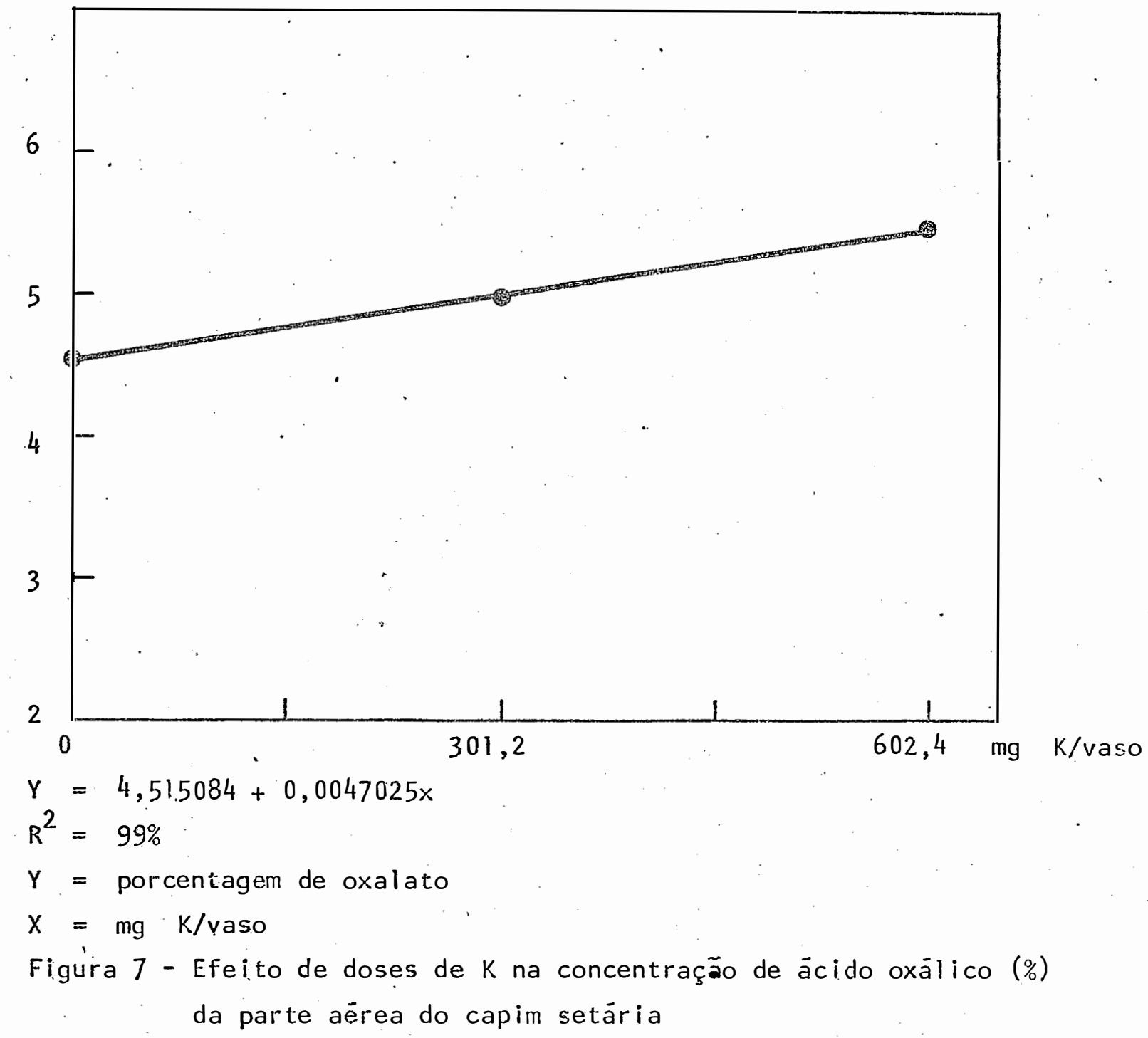


veis de potāssio, selecionou-se a equação de regressão de primeirograu (Figura 7 ).

Com relação à concentração de oxalato na matê ria seca, observa-se um aumento linear desse parâmetro com o acréscimo da dose de potássio empregadas, passando de 4,51\% (nível $K_{0}$ ) para $4,97 \%$ e $5,45 \%$ (nível $K_{0}$ e $K_{2}$ ), respectivamen te. Os resultados obtidos por diversos autores SMITH (1972) e JONES e FORD (1972) sobre o efeito da adubação potássica na concentração de oxalato no capim setaria foram confirmados no presente estudo. 0 fato de que a adubação nitrogenada não teve nenhum efeito sobre a concentração de oxalato confirmam os resultados dos trabalhos realizados por GONZALEZ e COWARD (1977) na Costa Rica.

Vale ressaltar que o nível de oxalato conside rado perigoso para saúde animal situa-se acima de $5 \%$ na matẹ ria seca (SEAWRIGHT et alii , 1970).

4.3. Efeitos dos Tratamentos sobre a concentração de Nitrogênio, Potässio, Cälcio e Magnésio.

Nas. Tabelas. 03 a 06 (Apêndice) são apresentadas, respectivamente, as: concentrações de nitrogênio, potảssio, cálcio e magnésio em porcentagem da matéria seca a $70^{\circ} \mathrm{C}$. As médias gerais, dess,es parâmetros, bem como, a anālise da variâncía são apresentadas, respectivamente, nas Tabe las 22 e 25 e Figuras 8 a 14 . 


\subsubsection{Nitrogênio}

Em relação às concentrações de nitrogênio na matéria seca, a anālise da variância acusou diferenças significativas para os niveis de nitrogênio e a interação nitro gênio versus potăssio (Tabela 22). Do estudo da regressão polinomial para os níveis de nitrogênio, selecionou-se a regressão linear (Figura 8 ).

$$
\text { As respostas, da espécie forrageị em estudo }
$$

às aplicações de nitrogênio revelou que para quilograma de nitrogênio aplicada hă um acréscimo de $0,0094 \%$ no teor des:se elemento na forragem. Essa resposta encontrada foi menor que a obtida por KOHMAN e AVILA (1976) que foi de 0,0063\%.

Se para um determinado consumo de matéria seca, 1,28\% de nitrogênio (NRC, 1984) è o nível minimo para atender as exigências nutricionais de animais adultos, podese concluir que o capim setaria com trinta e cinco dias de crescimento nos niveis $\mathrm{N}_{0}(0 \mathrm{~kg} / \mathrm{ha})$ e $\mathrm{N}_{1}(50 \mathrm{~kg} / \mathrm{ha})$ apresentaram valores abaixo do mínimo requerido, entretanto, os niveis $N_{2}(100 \mathrm{~kg} / \mathrm{ha}), N_{3}(150 \mathrm{~kg} / \mathrm{ha})$ e $N_{4}(200 \mathrm{~kg} / \mathrm{ha})$, respec tivamente, não se constituiria um fator limitante à produção animal.

4.3.2. Potāssio

Na Tabela 4 (Apêndice) são apresentados 
Tabel'a. 22 - Médias gerais da concentração de Nitrogênio, em \%, na parte aérea das plantas, em função dos níveis de $\mathrm{N}$ e $\mathrm{K}$ e o quadro de análise de variância (Média de 4 repetições)

\begin{tabular}{|c|c|c|c|c|c|c|}
\hline \multirow{2}{*}{ Niveis de K } & \multicolumn{5}{|c|}{ Níveis de $\mathrm{N}$} & \multirow{2}{*}{$\begin{array}{c}\text { Médias: } \\
\text { gerais dos } \\
\text { niveis de } k\end{array}$} \\
\hline & $\mathrm{N}_{0}$ & $N_{1}$ & $\mathrm{~N}_{2}$ & $\mathrm{~N}_{3}$ & $N_{4}$ & \\
\hline$K_{0}$ & 0,77 & 0,99 & 1,74 & 2,16 & 3,10 & 1,75 \\
\hline $\mathrm{K}_{1}$ & 0,72 & 0,65 & 1,59 & 1,63 & 2,55 & 1,42 \\
\hline $\mathrm{K}_{2}$ & 0,60 & 1,26 & 1,64 & 2,26 & 1,96 & 1,54 \\
\hline $\begin{array}{l}\text { Niveis gerais } \\
\text { dos niveis de } \mathrm{N}\end{array}$ & 0,69 & 0,96 & 1,65 & 2,01 & 2,53 & \\
\hline
\end{tabular}

ANÁLISE DE VARIANNCIA

\begin{tabular}{lcccccc}
\hline Causas da variação & G.L. & S.Q. & Q.M. & F & Prob.> F \\
\hline Nitrogènio & 4 & 27,2638855 & 6,8159714 & 186,0184 & 0,00001 \\
Potássio & 2 & 1,0715136 & 0,5357568 & 14,6216 & 0,00006 \\
Nitr. x Pot. & 8 & 3,3108364 & 0,4138546 & 11,2947 & 0,00001 \\
Resíduo & 45 & 1,6488625 & 0,0366414 & & \\
\hline Total & 59 & 33,2950980 & & & & \\
\hline
\end{tabular}

Mëdia geral $=1,578170$

C.V. $=12,129 \%$ 


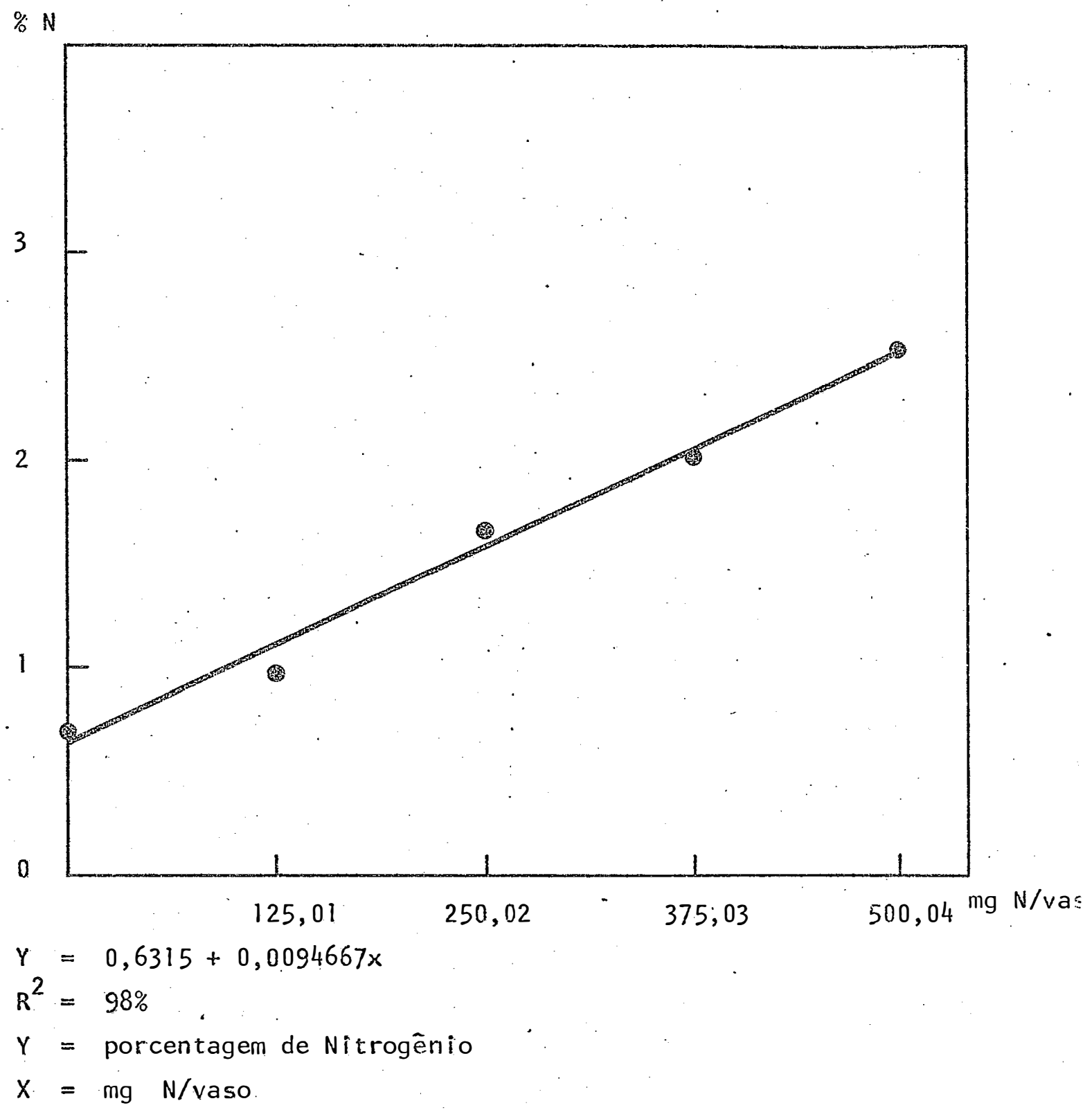

Figura 8 - Efeito de doses de $N$ na concentração de nitrogênio da parte aérea do capim setária 
teores de potássio da parte aērea do capim setaria, a $70^{\circ} \mathrm{C}$, obtidos pela aplicaçäo de doses de nitrogênio e potássio. enquanto que na Tabèla 23 são apresentadas as médias deste parâmetro e a análíse da variancia:

A análise da variância revelou haver diferen ças significativas nos teores de potássio para os diferen tes níveis de nitrogênio, potássio e a interação nitrogênio versus potássio (Tabèla 23.).

O efeito da dose de nitrogênio caracterizouse por uma regressão quadrātica (Figura 9 ), o que sugere que foram atingidos os teores tetos de potássio para esta forrageira, no presente experimento. Os teores de potássio na matēria seca produzida pelo nivel $\mathrm{N}_{0}(0 \mathrm{~kg} / \mathrm{ha}), \mathrm{N}_{1}$ (50 $\mathrm{kg} / \mathrm{ha}), \mathrm{N}_{2}(100 \mathrm{~kg} / \mathrm{ha}), \mathrm{N}_{3}(150 \mathrm{~kg} / \mathrm{ha})$ e $\mathrm{N}_{4}(200 \mathrm{~kg} / \mathrm{ha})$, fo ram $1,66 \%, 1,92 \%, 2,54 \%$ e 1,97\%, respectivamente (Tábela 23 ). Assim, segundo o NRC (1984) esses valores são bem maio res em relação à quantidade exigida pelos bovinos $(0,65 \%)$.

Com referência aos éfeitos das doses de potássio sobre os teores do elemento na matéria seca, caractẹ rizaram-se por regressões quadrática (Figura 10 ), o que sugere que foram atingidos niveás de potássio da forrageira em estudo para o presente experimento.

0 teor de potássio na matéria seca produzida pelo nivel $k_{0}(0 \mathrm{~kg} / \mathrm{ha}$ de $\mathrm{K}), \mathrm{K}_{1}(100 \mathrm{~kg} / \mathrm{ha}$ de $\mathrm{K})$ e $\mathrm{K}_{2}(200$ 
Tabela 23 - Médias gerais da concentração de Potässio, em \%, na parte aërea das plantas, em função dos níveis de $\mathrm{N}$ e. $\mathrm{K}$ e o quadro da anālise de variância (Mëdia de 4 repetições)

\begin{tabular}{cccccccc}
\hline \multirow{2}{*}{ Niveis de K } & \multicolumn{4}{c}{ Niveis de $N$} & . & $\begin{array}{c}\text { Médias } \\
\text { gerais } \\
\text { dos }\end{array}$ \\
\cline { 2 - 7 } & $N_{0}$ & $N_{1}$ & $N_{2}$ & $N_{3}$ & $N_{4}$ & niveis de K \\
\hline$K_{0}$ & 0,75 & 0,37 & 0,84 & 0,65 & 0,33 & 0,58 \\
$K_{1}$ & 1,40 & 0,94 & 2,53 & 2,10 & 2,28 & 1,85 \\
$K_{2}$ & 2,87 & 4,46 & 4,25 & 3,61 & 3,32 & 3,70 \\
\hline $\begin{array}{l}\text { Médias gerais } \\
\text { dos niveis de N }\end{array}$ & 1,67 & 1,92 & 2,54 & 2,12 & 1,97 & \\
\hline
\end{tabular}

\begin{tabular}{|c|c|c|c|c|c|}
\hline Causas da variação & G.L. & $S . Q$. & Q.M. & $F$ & Prob. $>F$ \\
\hline Ni trogênio & 4 & 5,0428691 & 1,2607173 & 45,0070 & 0,00001 \\
\hline Potāssio & 2 & $97 ., 1264496$ & 48,5632248 & 1733,6836 & 0,00001 \\
\hline Nit. $\times$ Pot. & 8 & 9,8036899 & 1,2254612 & 43,7484 & 0,00001 \\
\hline Resíduo & 45 & 1,2605213 & 0,0280116 & . & \\
\hline Total & 59 & 113,2335300 & $\therefore$ & & \\
\hline
\end{tabular}

Média geral $=2,046670$

C.V. $=8,178 \%$ 
$\% k$

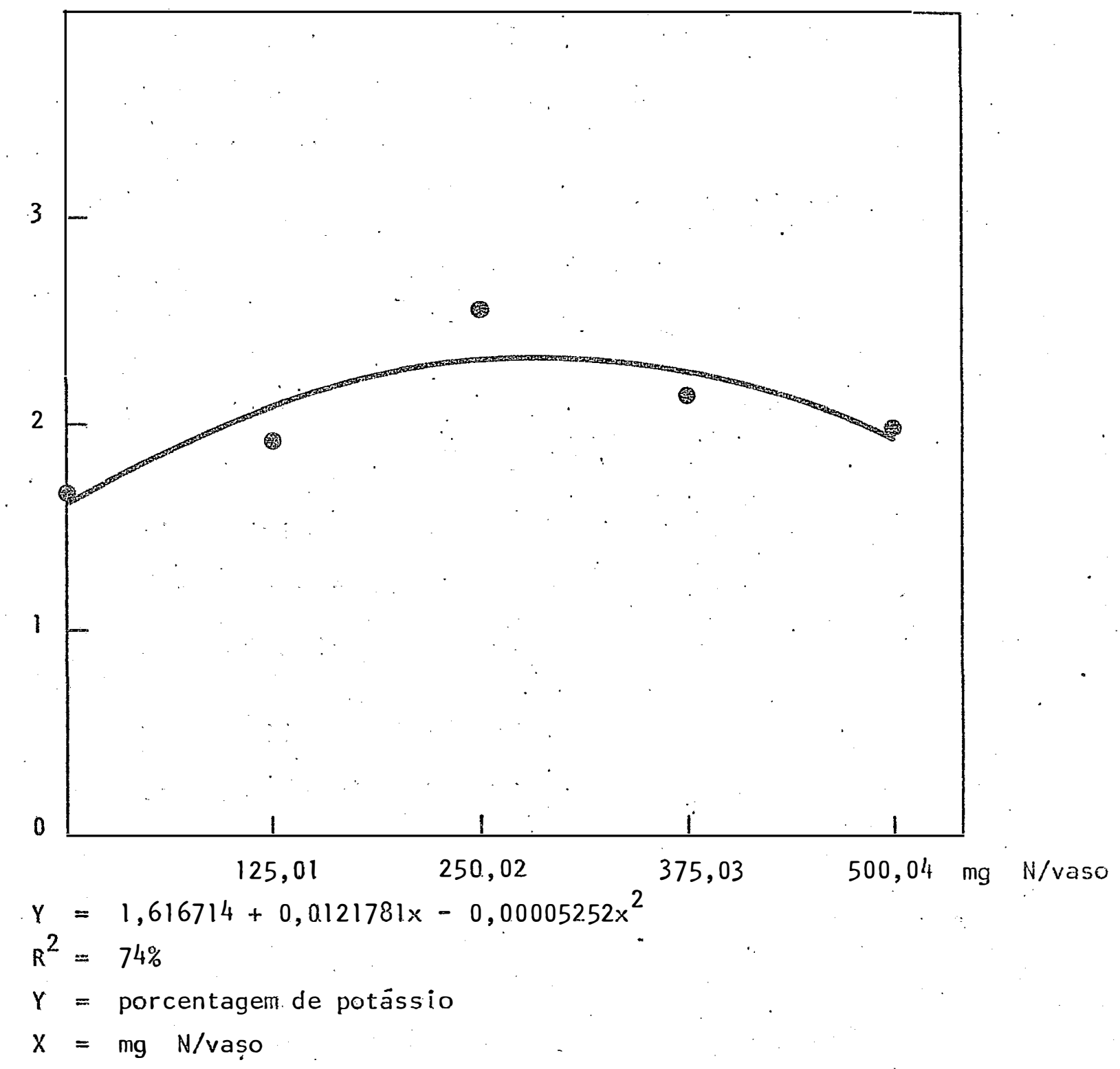

Figura 9 - Efeito de doses de $\mathrm{N}$ na concentração de potássio da parte aérea do capim setāria 
65

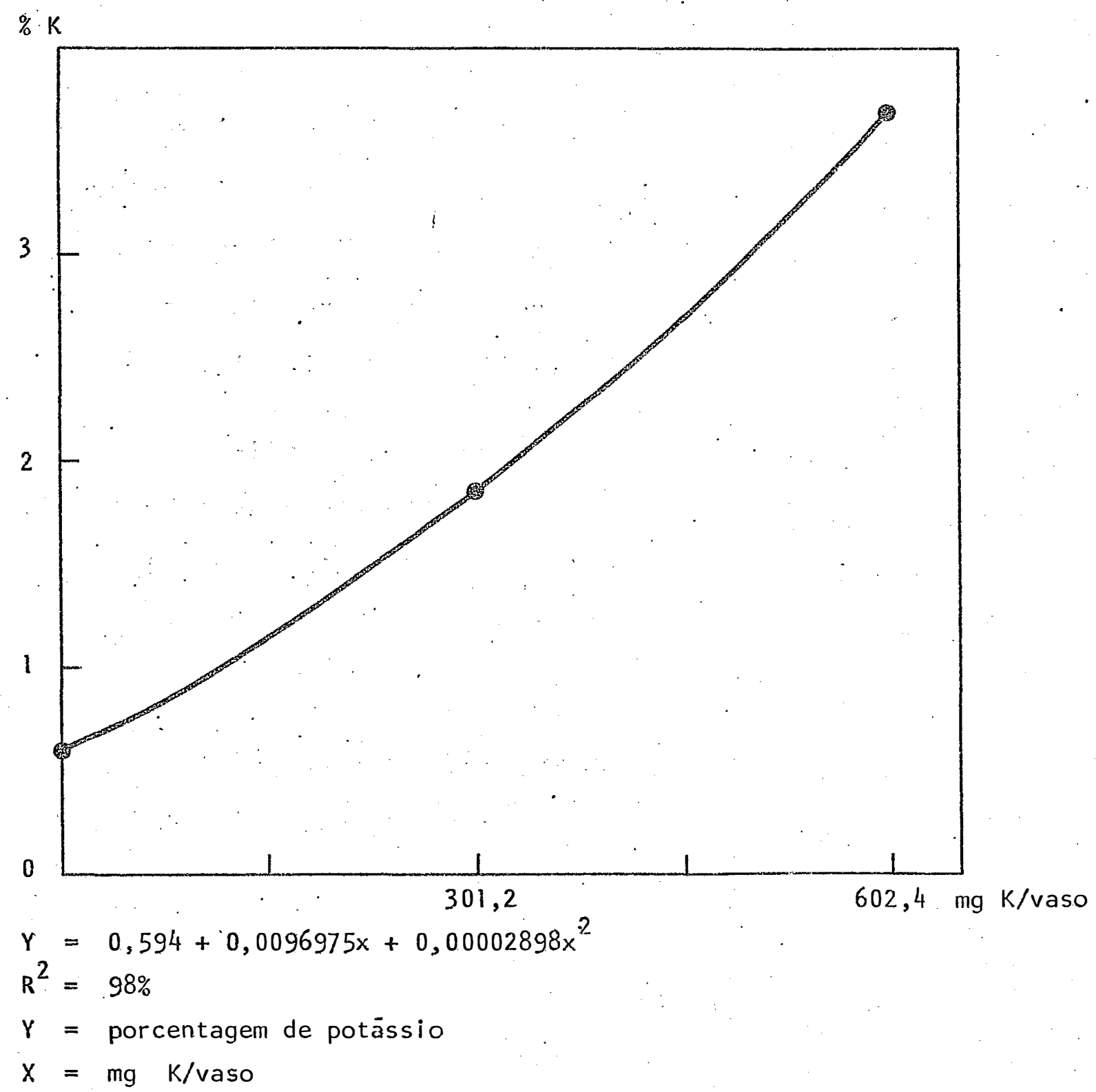

Figura 10 - Efeito de doses de potássio na concentração de potássio (\%) da parte aérea do capim setäria 
$\mathrm{kg} / \mathrm{ha}$ de K) foram. $0,58,1,85 \%$ e $3,69 \%$, respectivamente. № ta-se, de um modo geral, que os teores desses elementos foram altos em relação aos requerimentos nutricionais de um bovino adulto, que segundo a NRC (1984) è de $0,5 \%$ a $0,7 \%$ na matēria seca.

\subsection{3. cälcio}

Na Tabela $5{ }^{\circ}$ (Apêndice) são apresentados os teores de cálcio da parte aérea do capim setaria, a $70^{\circ} \mathrm{C}$, obtidas pela aplicação de dose de nitrogênio e potássio, enquanto que na. Tabela 24 são apresentadas as médias destes parâmetros e a análíse da variância.

Os resultados da añálise da variância revelou haver diferenças significativas no teor de cálcio para os diferentes níveis de nitrogênio, potässio e a interação nitrogênio versus potássio. (Tabela 24 ).

0. efeito de doses de nitrogênio caracterizou se por uma regressão cübica (Figura li). 0 teor de cálcio na matëria seca no nível $N_{0}(0 \mathrm{~kg} / \mathrm{ha}$ de $N), N_{1}(50 \mathrm{~kg} / \mathrm{ha}$ de $N), N_{2}(100 \mathrm{~kg} / \mathrm{ha}$ de $N), N_{3}(150 \mathrm{~kg} / \mathrm{ha}$ de $N)$ e $N_{4}(200 \mathrm{~kg} /$ ha de N) foram $0,41 \%, 0,32 \%, 0,37 \%, 0,41 \%$ e $0,38 \%$, respectivamente.

Se, para um determinado consumo de matéria seca, $0,18 \%$ de cálci.o (NRC, 1984), è o mínimo para atender as exigências nutricionais de um änimal adulto, os valores 
Tabela 24 Médias gerais da concentração de Cálcío, em \%, na parte aérea das plantas, em função dos niveis de $\mathrm{N}$ e $\mathrm{K}$ e o quadro de anälise de variância (Média de 4 repetições)

\begin{tabular}{|c|c|c|c|c|c|c|}
\hline \multirow{2}{*}{ Niveis de K } & \multicolumn{5}{|c|}{ Niveis de $\mathrm{N}$} & \multirow{2}{*}{$\begin{array}{c}\text { Médias } \\
\text { gerais dos } \\
\text { niveis de } \\
K\end{array}$} \\
\hline & $N_{0}$ & $\mathrm{~N}_{1}$ & $\mathrm{~N}_{2}$ & $\mathrm{~N}_{3}$ & $N_{4}$ & \\
\hline $\mathrm{K}_{0}$ & 0,40 & 0,43 & 0,36 & 0,45 & 0,44 & 0,41 \\
\hline$k_{1}$ & 00,42 & 0,20 & 0,45 & 0,40 & 0,37 & 0,36 \\
\hline $\mathrm{K}_{2}$ & 0,43 & 0,33 & 0,32 & 0,38 & 0,33 & 0,35 \\
\hline $\begin{array}{l}\text { Niveis gerais } \\
\text { dos niveis de }\end{array}$ & $N 0,41$ & 0,32 & 0,37 & 0,41 & 0,38 & \\
\hline
\end{tabular}

ANÁLISE DE VARIÁNCIA

\begin{tabular}{lccccc}
\hline Causas da variação & G.L. & S.Q. & Q.M. & F & Prob.x F \\
\hline Nitrogênio & 4 & 0,0666273 & 0,0166568 & 13,9714 & 0,00001 \\
Potăssio & 2 & 0,0386639 & 0,0193320 & 16,2153 & 0,00004 \\
Nit. x Pot. & 8 & 0,1436527 & 0,0179566 & 15,0616 & 0,00001 \\
Resíduo & 45 & 0,0536494 & 0,0011922 & & \\
\hline Total & 59 & 0,3025933 & & & \\
\hline
\end{tabular}

Média geral $=0,383667$

C.V. $\%=9,000 \%$ 


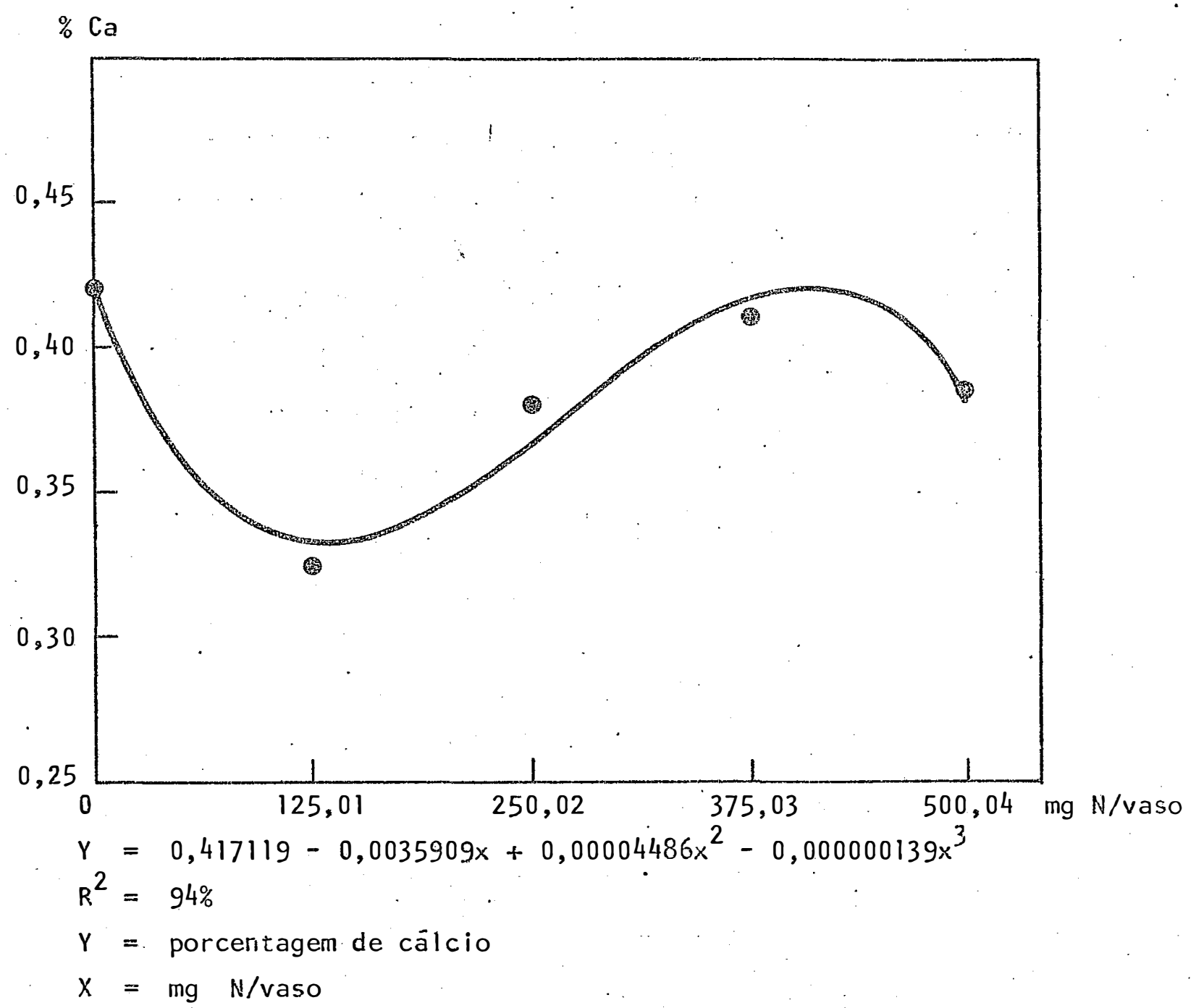

Figura 11 - Efeito de doses de $N$ na concentração de cálcio (\%) da parte aérea do capim setária 
encontrados na forrageira em estudo, não constituiria um fator limitante à produção animal.

Os efeitos da dose de potássio sobre o teor de cálcio na matéria seca do capim setaria, caracterizou se por uma regressão linear negativa (Figura 12 ), ou seja, à medida que se aumenta o nível de potássio houve uma diminuição no teor de cálcio na matéria seca.

A regressão linear negativa explica o antago nismo existente entre o potássio e o cálcio, o qual è bem abordado por REID e HORVATH (1980) e MALAVOLTA (1981).

$$
\text { De um modo geral, os teores de cálcio na }
$$

matēria seca $(0,35 \%$ a $0,41 \%)$, nos diferentes niveis de potässio, $K_{0}(0 \mathrm{~kg} / \mathrm{ha}$ de $K), K_{1}(100 \mathrm{~kg} / \mathrm{ha} \mathrm{de} \mathrm{K})$ e $K_{2}(200 \mathrm{~kg} /$ ha de K), estão acima do nível crítico. $(0,18 \%)$ considerado pelo NRC (1984) para a nutrição de bovinos.

\subsubsection{Magnésio}

Na Tabela 5: (Apêndice) säo apresentados os teores de magnésio da parte aérea do capim setaria, a $70^{\circ} \mathrm{C}$, obtidas pelá aplicação de doses de nitrogênio e potássio, en quanto que na Tabela 25 são apresentadas as médias desse parâmetro e a anālise da variância.

Os resultados da análise da variância revelaram haver diferença significativa nos teores de magnésio 
para os diferentes níveis de nitrogênio, potássio e a interação nitrogênio versus potássio (Tabela 25).

0 efeito das doses de nitrogênio caracter $\underline{i}$ zou-se por uma regressão linear positiva, ou seja, à medida que se aumenta o nível de nitrogênio houve um aumento no teor de magnésio na matéria seca, esse aumento corresponde a 0,00057\% no teor de magnésio para cada quilo de ni trogênio aplicado (Figura 13). A concentração de magnésio na matéria seca no nível $N_{0}(0 \mathrm{~kg} / \mathrm{ha}$ de $N), N_{1}(50 \mathrm{~kg} / \mathrm{ha}$ de $N), N_{2}(100 \mathrm{~kg} / \mathrm{ha}$ de $N), \mathrm{N}_{3}(150 \mathrm{~kg} / \mathrm{ha}$ de $N)$ e $\mathrm{N}_{4}(200$ $\mathrm{kg} / \mathrm{ha}$ de $\mathrm{N}$ ) foram $0,29 \%, 0,33 \%, 0,38 \%$ e $0,41 \%$, respectivamente.

os teores mínimos e máximos de magnésio na matéria seca da, parte aérea do capim setaria $(0,29 \%$ a $0,47 \%)$ indicam que para a forrageira em estudo não deverá haver risco de ocorrência da hipomagnesia se consideramos as exi gências nutricionais de um bovino adulto como sendo de $0,10 \%$ na matēria seca (NRC, 1984).

0 tratamento com potássio, caracterizou-se por uma regressão quadrática negativa (Figura 14), o que. sugere ter havido uma interação negativa de potássio versus magnésio, ö que è bem abordado por REID e HORVATH (1980). .

A matéria seca produzida pelo nivel $k_{0}(0 \mathrm{~kg} /$ ha da K), $K_{1}\left(100 \mathrm{~kg} / \mathrm{ha}\right.$ de K) e $K_{2}(200 \mathrm{~kg} / \mathrm{ha}$ de $\mathrm{K})$, apresentạ ram um teor de magnésio de $0,47 \%, 0,31 \%$ e $0,29 \%$, respecti- 
Tabela 25 - Médias gerais da concentração de Magnésio, em \%, na parte aérea das plarıtas, em função dos níveis de $\mathrm{N}$ e. K e o quadro de análise de variância (Média de 4 repetições)

\begin{tabular}{|c|c|c|c|c|c|c|}
\hline \multirow{2}{*}{ Niveis de K } & \multicolumn{5}{|c|}{ Niveis de $\mathrm{N}$} & \multirow{2}{*}{$\begin{array}{c}\text { Niveis } \\
\text { gerais } \\
\text { dos } \\
\text { niveis de K }\end{array}$} \\
\hline & $N_{0}$ & $N_{1}$ & $\mathrm{~N}_{2}$ & $\mathrm{~N}_{3}$ & $N_{4}$ & \\
\hline $\mathrm{K}_{0}$ & 0,35 & 0,48 & 0,42 & 0,51 & 0,59 & 0,47 \\
\hline $\mathrm{k}_{1}$ & 0,27 & 0,21 & 0,40 & 0,34 & 0,35 & 0,41 \\
\hline $\mathrm{K}_{2}$ & 0,27 & 0,30 & 0,29 & $0 ; 129$ & 0,30 & 0,29 \\
\hline $\begin{array}{l}\text { Niveis gerais } \\
\text { dos niveis de N }\end{array}$ & 0,29 & 0,33 & 0,37 & 0,38 & $0,41$. & \\
\hline
\end{tabular}

\begin{tabular}{lccccr}
\hline Causas da variação & G.L. & S.Q. & Q.M. & F & Prob. >.F \\
\hline Nitrogênio & 4 & 0,1010171 & 0,0252543 & 17,2255 & 0,00001 \\
Potássio & 2 & 0,3934905 & 0,1967453 & 134,1964 & 0,00001 \\
Nit. x Pot. & 8 & 0,1198429 & 0,0149804 & 10,2178 & 0,00001 \\
Resíduo & 45 & 0,0659745 & 0,0014661 & & \\
\hline Total & 59 & 0,6803250 & & & \\
\hline
\end{tabular}

Média geral $=0,362500$

C.V. $\%=10,563 \%$ 


\section{$\% \mathrm{Ca}$}

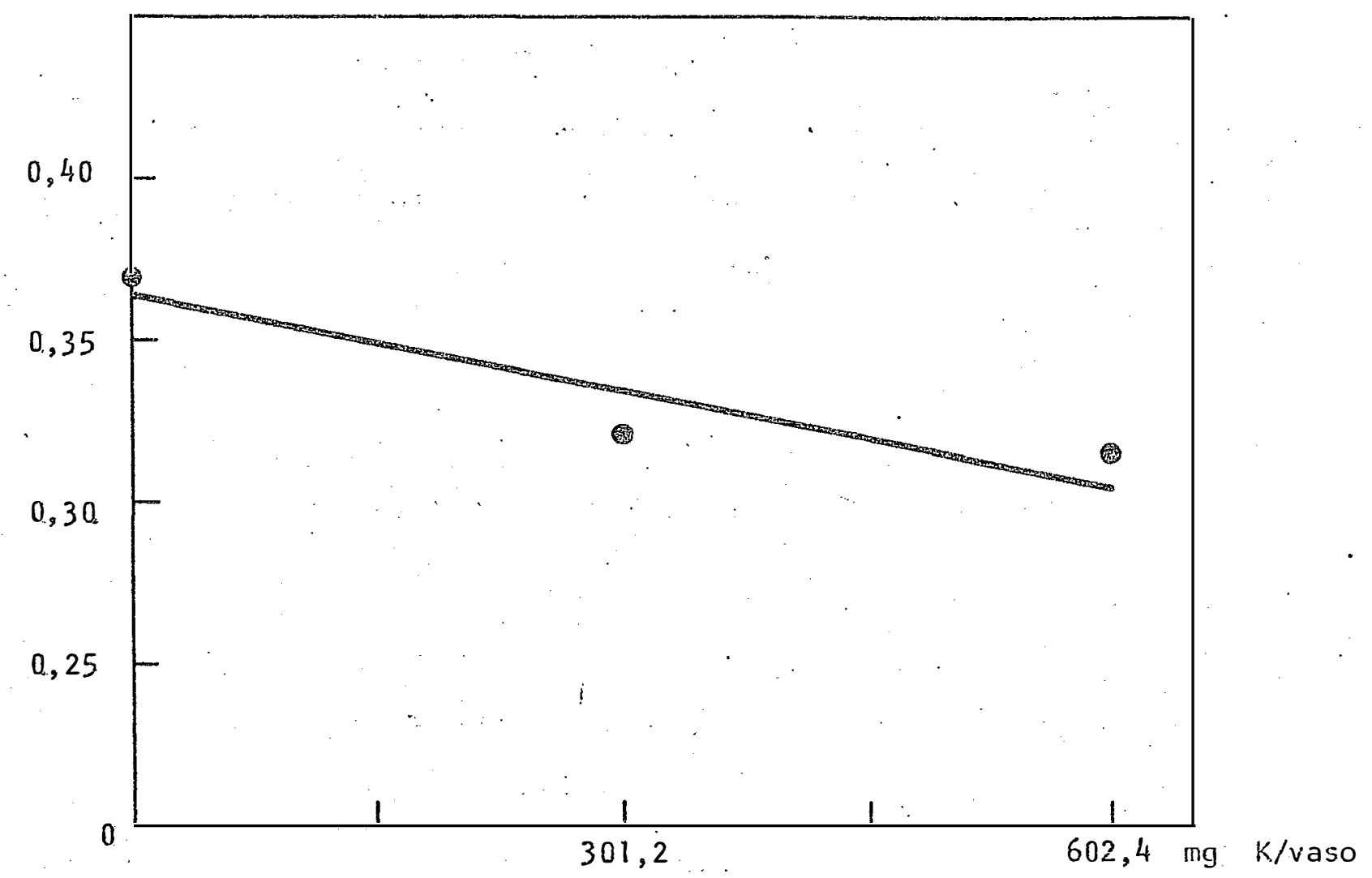

$Y=0,412917-0,0002925 x$

$R^{2}=88 \%$

$Y=$ porcentagem de cálcio

$\mathrm{X}=\mathrm{mg} \mathrm{K} /$ vaso

Figura 12 - Efeito de doses de K na concentração de câlcio (\%) da parte aẻrea do capim setäria 


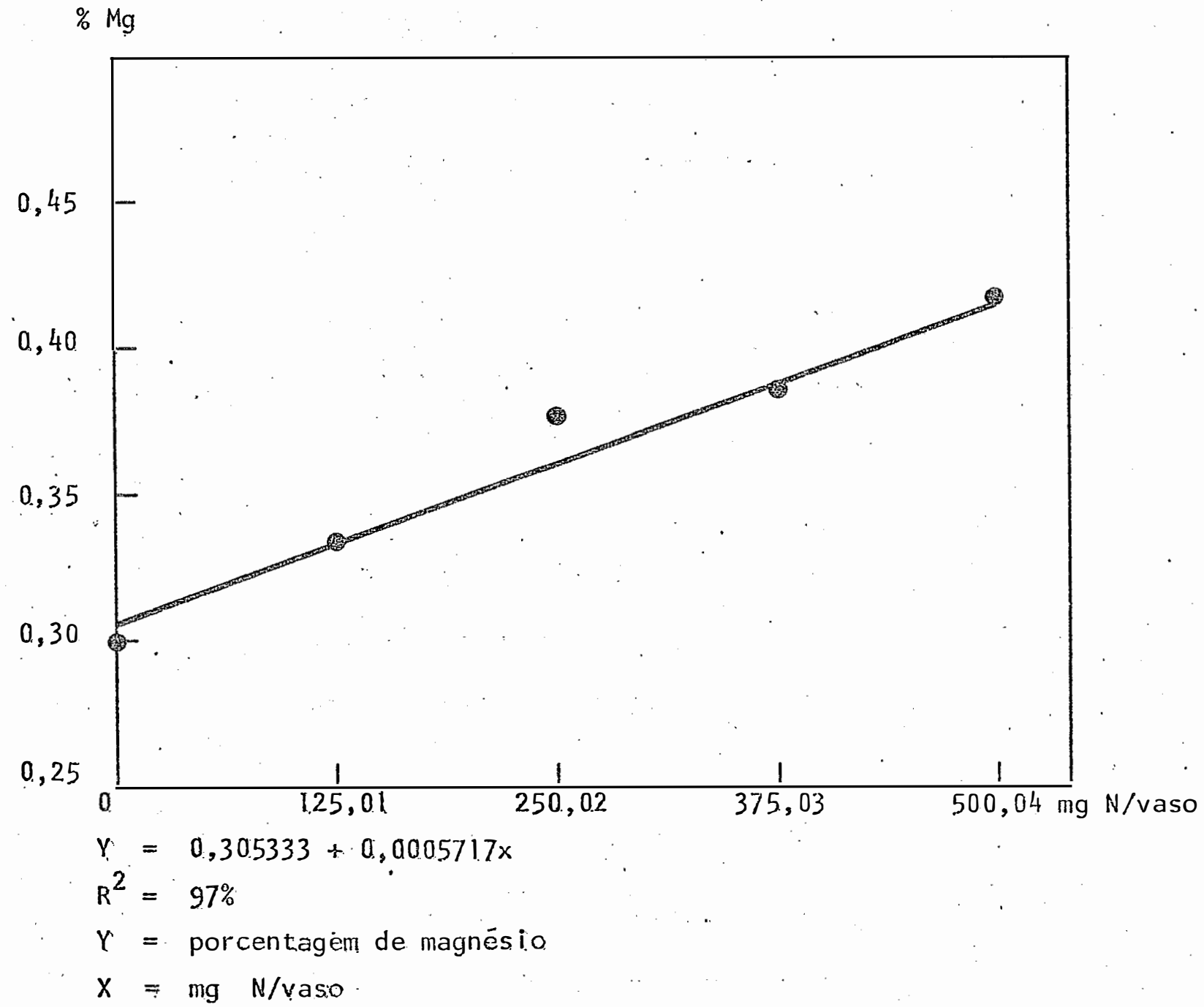

Figura 13 - Efeito de doses de $\mathrm{N}$ na concentração de magnésio (\%) na parte aérea do capim setäria 


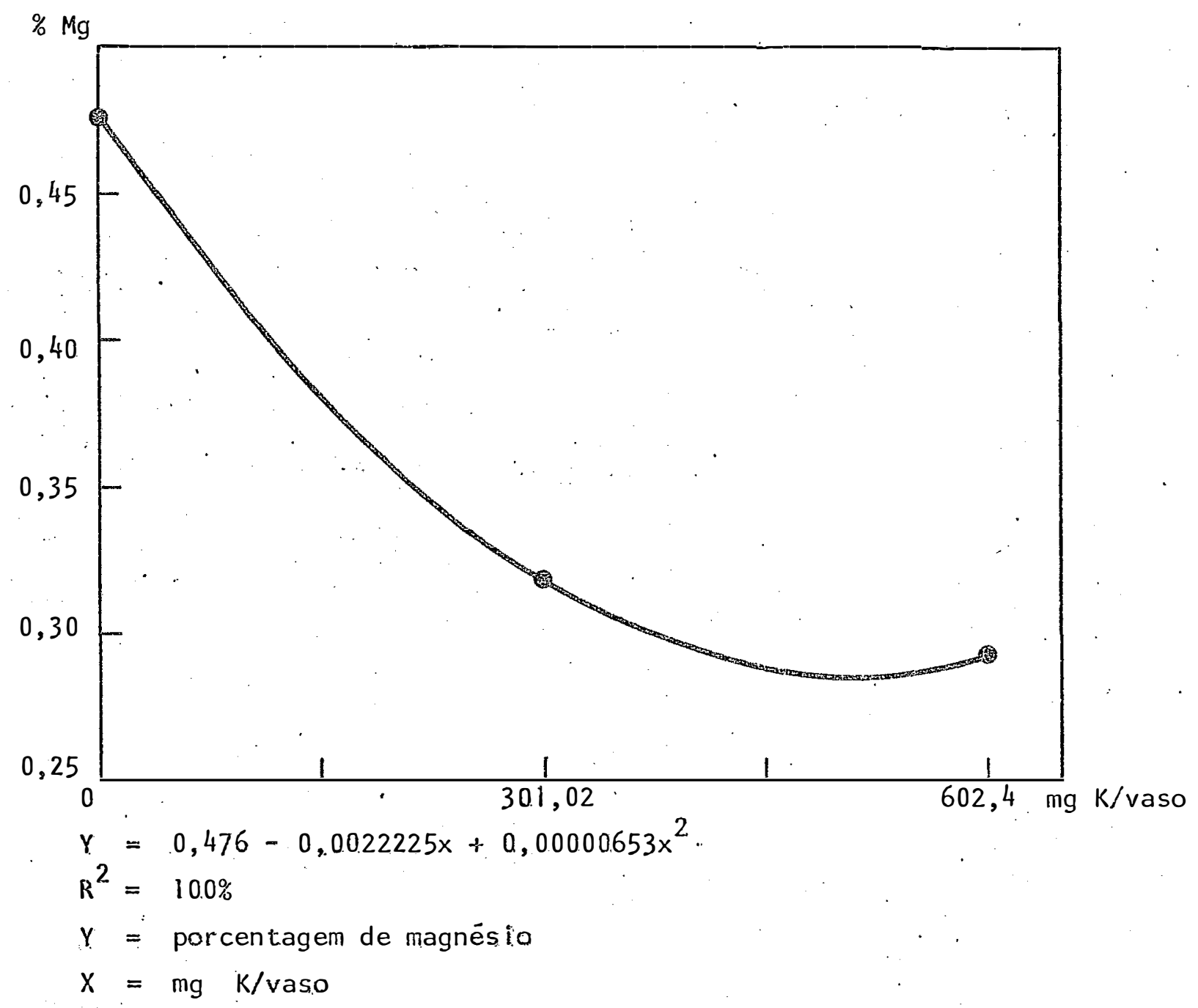

Figura 14 - Efeito de doses de $K$ na concentração de magnésio (\%) na parte aérea do capim setária 
vamente. Apesar de existir uma diminuição no teor de magnẹ sio em cada nível de potásío utilizado, o valór mínimo des se elemento se encontra acima do nível critico $(0,10 \%)$ considerando para nutrição de um bovino adulto' segundo a 'NCR (1984)

4.4. Efeito dos tratamentos sobre os teores de cálcio e oxalato e a relação cálcioloxalato na matéria seca

os dados das Tabelas 2 e 5 (Apêndice) aprẹ sentam os teores de oxalato e cálcio da parte aérea das plantas, enquanto que na Tabela 26 são apresentadas as médias da relação cālcio:oxalato em função dos níveis de ni trogênio e potássio.

De um modo geral, os dados encontrados na relação cālcio/oxalato na matérià seca da forrageira em estudo, mostram valores muito baixos $(0,08 \%$ a $0,06 \%)$ para a nutrição animal, considerando que umá relação cálcio/oxalato menor que $0,5 \%$ são potencialmente perigósas para a saú de animal, em especial, eqüinos (BLANEY et alii, 1984a).

Note-se que apesar.de o teor de cālcio na forrageira em estudo encontrar-se acima dos valores conside rados críticos para a nutrição animal, pelo NRC (1984), o balanço negativo do cálcio é ocasionado quando o oxalato f xa esse elemento, o que provoca o hiperparateriodismo nutri cional secundário (NSH) o que é bem abordado por GROENENDYK e SEAWRIGHT, 1974. 
Tabela 26 - Médias gerais da relação cálcio:oxalato em \% na matéria seca da parte aérea do capim setaria (Média de quatro repetições)

\begin{tabular}{|c|c|c|c|c|c|c|}
\hline N.íveis & \multicolumn{5}{|c|}{ Niveis de $\mathrm{N}$} & \multirow{2}{*}{$\begin{array}{c}\text { Médias } \\
\text { gerais } \\
\text { dos } \\
\text { niveis de:k }\end{array}$} \\
\hline de $K$ & $N_{0}$ & $N_{1}$ & $N_{2}$ & $N_{3}$ & $\mathrm{~N}_{4}$ & \\
\hline$K_{0}$ & 0,09 & 0,10 & 0,07 & 0,09 & 0,08 & 0,086 \\
\hline$k_{1}$ & 0,07 & 0,04 & 0,09 & 0,08 & 0,06 & 0,068 \\
\hline$K_{2}$ & 0,07 & 0,05 & 0,06 & 0,06 & 0,06 & 0,060 \\
\hline \multicolumn{2}{|c|}{$\begin{array}{l}\text { Medias gerais, } 0,076 \\
\text { niveis de } N\end{array}$} & 0,063 & 0,073 & 0,076 & 0,066 & \\
\hline
\end{tabular}




\section{Conclusões}

Nas condições do presente experimento,

resultados permitem concluir que:

- Para se obter uma máxima produção de matēria seca do cápim setāria, è necessārio observar a interação (efeito associativo) da fertilização nitrogenada versus potàssica.

- O potássio influi direta e positivamente sobre o conteūdo de oxalato na parte aērea da espécie forragei ra estudada.

- 0 nitrogẽnio não interfere diretamente no teor de oxalato, mas sim no efeito de potássio sobre o oxala. to.

- De um modo geral, adubações nitrogenada e, principalmente, potássica, faz elevar os niveis de oxalato em relação à saūde animal. 
- Os teores de nittrogênio, potāssio, cálcio e magnésio na matéria seca do capim setaria colhido aos 35 dias de desenvolvimento, apresentaram-se suficientes para atender as exigencias nutritivas do gado de corte (adulto em manutenção).

- A relação cálciofoxalato na matéria seca do capim setaria apresenta valores muito abáixo do mínimo rệghuerido para a saudãvel nutrição animal, em especial, eqúi nos.

- O capim setaria pode ser considerado como uma planta forrageira indicada para explorações intensivas, desde que convenientemente manejada no que tange a sua fer-. ti lização. 
6. Literatura Citada

ABRAMIdES, P.L.G.; N:M.F. MEIRELLES e D. BIACHINE. 1980. Considerações gerais sobre Setaria anceps. Zootècnia, Säo Paulo, 18(4):219-50.

ALCÃNtARA, P.B.; P.L.g. Abramides e G.L. ROCHA. 1979. Efeito da quantidade de leguminosas presentes em pastagens de gramineas tropicais, sobre o peso de bovinos de corte. Zootecnia. Säo Paulo, 17 (4):225-28.

ALLISON, M.J.; E.T. LITTLEDIKE e L.F. JAMES. 1977. Changes in ruminal ovalate degradation rates associated with adaptation to oxalate ingestion. Journal. of Animal. Science, $\underline{45}(5): 1173-1179$.

BARNARD, C. 1972. Register of australian herbage plant cultivars. Camberra, Division of Plant Industry, C.S.I.R.0.: 260p.

BLANEY, B.J.; R.J.W. GARTNER E R.A. MC KENZIE. 1981a. The inhability of horse to absorb calcium from calcium oxalate. Journal Agricultural Science. Cambridge, 97:639-641. 
BLANEY, R.B.; R.J.W. GARTNER e R.A. MC KENZiE, 1981b. The effects of oxalate in some tropical grasses on the availability to horses of calcium, phosphorus and magnesium. Journal Agricultura Science. Cambridge, 97: $507-514$.

BLANEY, B.J.; R.J.W. GARTNER e T.A. HEAD. 1982. The effect of oxalate in tropical grasses on calcium, phosphorus and magnesium availability. Journal Agricultural Science. Cambridge, 99:533-539.

BOGDAN, A.V. 1977. Tropical pasture areal fodder plants; grass and legumes. London, Longman, 475p. (Tropica) Agricultural Series).

BOONMAN, J.G. 1971. Experimental studies on seed production of tropical grasses in Kenya. 2. Tillering and breading in seed crops of eight grasses. Netherlands Journal Agricultural Science. Wageningen, 19:237-249.

BOLDRINI, 1.1. 1976. Gramíneas do gênero Setaria, Blav., no Rio Grande do Sul. RPFo, Porto Alegre, 3:331-422. Anuärio Téćnico.

CANTO, A.C.; B.A. BEHNECK; E.MORAIS E L.B. TEIXEIRA. 1979. Comportamento produtivo de forrageira introduzida no territörio federal de Roraima. In: REUNIÃO ANUAL DA SOCIEDADE BRASILEIRA DE Z00TECNIA, 16\%, Curitiba, 1979, Vol. 2. Anais. Curitiba, p. $219-220$. 
CASAGRANDE, J.C. e O. de SOUZA CORREA, 1980. Efeito de níveis de enxôfre sobre quatro gramíneas forrageiras tropicais. Pesquiza Agropecuaria Brasileira. Brasília, 17(1): $21-25$

CASTILLOS, M.Z. e L.I. BARRET0. 1981. Competição entre cultivares de Setaria anceps sob o efeito de doses de nitrogênio e/ou leguminosas. Revista Ci ências Rurais,.11(1): $63-74$

CUNHA, N.G.; A. POTT; J.A. COMASTRI FILHO; J.C. CASAGRANDE; J.F. DYNIA e W. COUTO. 1981. Respostas de forrageiras a nutrientes em solo de planície sedimentar do Rio Taquari, Pantanal Matogrossense, Corumbā, MT. Pesquiza Agropecuaria Brasileira, Corumbá. i3 p. (Circular Técnića 18).

DEINUM, B. e P.G.J. DIRVEN. 1977. Climate, nitrogen and grasses. 7. Comparison of production and chemical composition of Brachiaria ruziziensi and Setaria sphacelata grown at different temperatures. Netherlands Journal. Agricultural Science. Wageningen, 24:67-78.

DIJK SHOORN, W. 1973. Organic acids, and their role in ion uptake. In: E.W. BUTLER e R.W. BAILEY Ed. Chemistry and Biochemistry of Herbagé. Vol:11. 163-167. 
DOBSON, M.E. 1959. 0xalate ingestion studies in the sheep.

Australian Veterinary Journal. Melbourne, Vic., 53(1):225-233.

EBERSOHN, J.P. e J.C. MULDER. 1980. Effects of nitrogen

Hefertilizer and white clover on dry matter nitrogen yield

of Digitaria decumbens and Setaria sphacelata var. sericea

in South-Eastern Queensland. Australian Journal Experimental.

Agriculture and Animal, Husbandry, Melbourne, 20(106):582-86.

GARCIA, R.J. e M.P. MORRIS, 1955. 0xalate content of tropical forrage grasses. Science, $122(31): 1089$.

GARTNER, R.J.W.; B.J. BLANEY e R.A. MC KENZIE, 1981. Supplements to correct oxalate-induced negative càlcium and phosphorus balances in horses fed tropical grass hays. Journal Agricultural Science. Camberra, 27:581-589.

GODINHO, F.J. 1968. Capim marangä (Setaria sphacelata) uma nova forrageira. Turrial ba, 18 (3):297-8.

GONZALEZ, R. e V. COWARD. 1977. Efeito del intervalo de corte y la fertịlización nitrogenada en el contenido de àcido oxálico del pasto San Juan (Setaria sphacelata) en dos zonas de Costa Rica. Agronomia Costaricense, San José, $1(1): 17-21$.

GRIEVE, M.C. E F.D. OBBOURN. 1965. The nutritional value of some tropical grasses. Journal Agricultura Science, 65:411-417. GROENENDYK, S. e A.A. SEAWRIGHT. 1974. 0steodystrophia fibrosa in horse grazing Setaria sphacelata. Australian Veterinary HACKER, J.B. ER.J. JONES, 1969. The Setaria sphacelata complex;

a review. Tropical Grassland, Brisbane, 0d., $\underline{3}(1): 13-34$. 
HACKER, J.B. 1972. Seasonal distribuition in. Setaria.

Australian Journal of Experimental Agriculture and

Animal. Husbandry, 12:36-42.

HACKER, J.B.; B.J. FORD e J.M. GOW. 1974. Simulated frosting of tropical grásses. Australian Journal Agricultural. Research. Melbourne, $\underline{25}(1): 45-7$.

HINIZ, H.F. 1983. Equine nutrition research in Australia. Feed International (Circular Técnico, 21 ).

HOAGLAND, D.R. e D.I. ARNON. 1950. The water culture method for growing plants without soil. Berkeley, California, Agricultural Experiment Station (Circular 347).

HEYN, R. e A. MOREL. 1982. Efecto de diferentes frecuencia de cortes en el rendimento de la produra natural y tres plastos cultivados. Programa Nacional de Investigación. y Extensión Ganadera, San Lorenzo-Paraguay, 209p. Informe Anual.

HUMPHREYS, L.R. 1974. A guide to better pastures for the tropics and subtropics. 3 ed. Fleminton. Writh Stephenson.

JONES, R.M. 1969. Mortality of some tropical grasses and legumes following frosting in the first winter after sowing. Tropical Grassland, Brisbane, $\underline{3}(1): 57-63$. 
JONES, R.J.; A.A. SEAWRIGHT E D. A. LITTTLE. 1970. 0xalate poisoning in animals grazing the tropical grass setaria sphacelata. Journal Australian Institute Agricultural. Science, St. Lucia, Qd., $36(1): 41-43$.

JONES, R.J. E:C.W. FORD. 1972a. Some factors affecting the oxalate content of the tropical grass Setaria sphacelata. Australian Journal of Experimental Agriculture and Animal. Husbandry, $\quad$ I2 $(57):$

JONES, R.J. e C.W. FORD. 1972b. The soluble oxalate content of some tropical grosses grown in South-East Queensland. Tropical Grassland, Brisbane, Qd., 6(3):201-204.

KEMP, 0.R. 1976. The. seasonal growth of tropical pasture grosses on the mid north coasth of N:S.W. Herbage Abstract, Farnham Royal 46(2):68. Resumo do trabalho publicado in: Journal of the Australian. Institute of Agriculture Science, Sydney $41: 50-57$

KOHMANN, C. e R.V.J: ÁVILA. 1979. Rendimentos, qualidade e persistência em Panicum maximum Jać. c.v. Gatton e Setaria anceps c.v. Kazungula, colhidos em três estädios de crescimentos, a duas alturas de corte, acima do solo e sob três doses de nitrogênio. Anuärio Técnico do Instituto de Pesquisas Zootēcnicas Francisco 0sörio", Porto Ale gre, $6: 229-343$. 
LUCK, P.E. 1979. Setaria a important pasture grass. Queensland Agricultural Journal: $105(2): 136-144$.

MALAvolta, E. 1981. Manual de Química Agrícola - Adubos e Adubação. Editora Agronōmica Ceres. São Paulo. 597p.

MALHERBE, C.E. 1969. Influence of nitrogenous and fosfatic fertilizer in Setaria sphacelata in South Africa. Journal British Grassland Science, 24(1):45-49.

MATHAMS, R.H. e A.K. SUTHERLAND. 1952. The oxalate content of some Queensiland pastures plants. Queensland Journal. Agricultural Science, Brisbane, $\underline{g}(4): 317-334$.

MCDONALD, 1.W. 1982. Detrimental substances in plants consumed by carazing ruminants. In MORLEY, F.H.W. Ed. Grazing Animals. Vol.. l-Elsevier Scientific Publishing Company. Amsterdan, 349-358.

MC KENZIE, R.A.; B.J. BLANEY e J.W. GARTNER. 1984. The effect of dietary oxalate on calcium, phosphorus and magnesium balances in horses. Journal Agricultural Science, 97:69-74.

MC KENZIE, R.A. e K. SCHULTZ. 1983. Confirmation of the presençe of calcium oxalate crystoes in some tropical grasses. Journal Agricultural Science. Cambridge, 100 : $249-25$.

MENDONÇA, A. e H:B.:MATTOS: 1976. Oxalato em Setaria anceps. em peoblema em pastagens tropicais e sub-tropicais. são Paulo. Zootecnia, 11 (3):181-18k. 
MIDDLETON, C.H. 1970. Some effects of 'grass-legume bowing rates on tropical species establishment and production. In: INTERNATIONAL GRASSLAND CONGRESS, 11 , Surfers Paradise. 1970. Proceedings. Queensland, University dif Queensland Press, $119-123$.

MIDDLETON, C.H. 1973. Effects of sowring rate on yield composition of siratro-nandi Staria pasture. Queensland, Journal of Agricultural and Animal Science. 30:39-52. MIDDLETON, C.H. e G.A. BARRY. 1978. A study of oxalate concentration in five grasses in the wet tropics of Queensland. Tropical Grassland, Brisbane, $12(1): 28-35$.

MOIR, K.W. 1953. The determination of oxalic acid in plants. Queensland Journal Agricultural Scierice. 10:1-3. MOLAS, O.A.; J. CASACCIA; H. RACHI e A.B. GUILERA. 1982. Determinación de características agrostolōgicas y seleccion de plantas forrageras introduzidas en la - estación experimental del Chaco. Informe Anual Programa Nacional de Investigación y Extensiōn Ganadera. San Lorenzo - Paraguay. $209 p$.

NDYANABO, W.K. 1974. Oxalate control of some commonly grazed pasture forrages of Lango and Acholi Districts of Uganda. East African Agriculture for Journal. Nairobi, 39(3): $210-214$. 
NRC. 1984. Nutrients requirements of domestics animals. VI. Nutrient requirements of beef cattle. National Research-Council. National Academic of Sciences. Washington, D.C. 90p.

NUNES, S.G.; J.M. VIERA e J.C. DE SOÚSA. 1979. Avaliação de cinco gramineas tropicais em solo de cerrado, sob condições de pastejo. Campó Grande, MS, EMBRAPA-CNPGC, 3p. (Comunicado Tëcnico, 6).

OLSEN, F.J. 1972. Effect of large aplications of nitrogen fertilizer on the productivity and protein content of four tropical grasses in Uganda. Tropical Agriculture, $49(3): 251-260$.

PEDREIRA, J.V. 1973. Crescimento estacional dos capins coIonião (Panicum maximum, Jacq.), gordura (Melinis minutiflora, Paul de Beauv.), jaraguá (Hyporrhenia rufa, Ness) e pangola Taiwan A-24 (Digitaria pentzii, Stent). Piracicaba, ESALQ/USP. 117p (Tese de Doutoramento).

PEDREIRA, J.V.S.; P. NUTI e B.C.S. CAMPOS. 1975, Competição de capins para produção de matēria seca. Boletim de $\ln$ dūstria Animal. São Paulo, $\underline{32}(2): 319-23$.

PEREIRA, R.M.A.; D.J. SYKES; J.A. GOMIDE E G.T. VIDIGAL. 1966. Competição de dez gramíneas no cerrado em 1965. Revista Ceres, Viçosa, MG. 13 (74):141-53. 
PIMENTEL, D.M. 1976. Intensidade, frequência de cortes e nitrogênio sobre os rendimentos de matéria seca e proteina bruta de Setaria anceps Stapf. c.v. Kazungula. Porto Alegre. Faculdade de Agrónomia, UFRGS.

PIMENTEL, D.M. 1974. Intensidade, frequência de corte e nitrogênio sobre os rendimentos de matéria seca e proteína bruta de Setaria anceps c.v. Kazungula. Porto Alegre, Faculdade de Agronomia. U.F.R.G.S.

PIMENTEL, D.M. e H.A. 1983. Capim setaria. Características e aspectos produtivos. Pesquiza Agropecuária Brasileira. Brasilia, 11 p. (Documento 11).

PUPO, H.N.J. 1984. 0xalato, um fantasma da Equinocultura. Centaurus. $1: 44-49$.

RAIJ, B.U. e J.A. QUAGglo. 1983. Mëtodos de ạaálises de so lo para fins de fertili idade, Campinas, S.P. I.A.C. (Boletim Técnica, 8 I). 31 p.

RANZANI, G.; 0. FREIRE e T. KINJO. 1966. Carta de Solos do Municipio de Piracicaba. Centro de Estudos de Solos. ESALQ/USP. Piracicaba- SP.

REID, R.L. e D.J. HORVATH. 1980. Soil chemistry and mineral problems in farm livestock. A review. Animal Feed Science. and Technology. 5:95-167. 
RIMINGTON, C. e D.G. STEYN. 1933. Psilocaúlon alsimile N,E. Br. as Stock Poisson. 1. Determination of 0xalic, Malic, Sertanic Acids, etc. Onderstepoort Journal. of Veterinary Science and Animal Industry. $1(2): 439-45$.

ROUGHAN, P.J. E.J. WARRINGON. 1976. Effect of nitrogen source on oxalate accumulation in setaria sphacelata. (cv. Kazungula). Journal Science Food Agriculture, 27: $281-286$

ROUGHAN, P.G. e.C.R. SLACK. 1 1973. Simple methods four rutine screening and quantitative estimations of oxalate content of tropical grasses. Journal Science Food Agriculture, $24: 803-811$.

SARRUGE, J.R. e H.P. HAAG. 1974. Anālises químicas em plantas. E.S.A. "Luiz de Queiroz", Piracicaba, SP. 57 p. (mimeografado).

SCHENK, M.A.M.; T.T. FARIA; D.M. PIMENTEL E L.R.L. THIAGO. 1982. Intoxicação por oxalato em vacas lactantes em pastagens de Setaria. Pesquisa Agropecuāria Brasileira. Brasí$1 \mathrm{ia}, \underline{19}(9): 1403-1407$. 
SEAWRIGHT, A.A.; S. GROENENDYK 'e K.G. SILVA. 1970. An outbreak of oxalate paisoning in cattle grazing Setaria sphacelata. Australian Veterinary Journal. Melbourne, Vic., 46:293-296.

SHARMA, M.K.; B.R. UPADHYAYA E J.S. SAXURA. 1973. Setaria sphacelata. A promising fodder for sheep I. Studies on palatability and nutritive value. Indian Veterinary Journal. $49(11): 1137-40$.

SMITH, F.H. 1972. Potassium nutrition, ionic relations and oxalic acid accumulation in three cultivars of setaria sphacelata. Australian Journal Agricultural Research. Melbourne,Vic., $\underline{23}: 969-980$.

SMITH, F.H.,1979. Tolerance of seven tropical pasture grasses to excess manganese. Commun In. Soil Science and Plant. Analysis, $10(5): 853-867$.

SONEJI, V.S.; S.R. MUSANGI e J.F. OLSEN. 1971. Digestibility and feed intake investigations at different stages of growth of Brachiaria ruziziensi, Chloris goyana and Setaria sphacelata using corriedal wether sheep. 1. Digestibility and voluntary intake. East African Agricultural and Forestry Journal, $37(2)$ : $125-128$

STOBBS, H.T. 1973. The effect of plant structure on the intake of tropical pasture II. Difference in sward strutura, nutritive value, and bite size of animals grazing Setaria anceps. and Chloris gayana at various stagens of growth. Australian. Journal Agricultural Research, 24:821-829. 
STRICKLAND, R.W. 1978. The coal season production of some introduced grosse in South-East. Queensland Tropical Grassland, Brisbane, 12:102-112.

THAIRU, D.M. 1972. The contribution of Desmodium uncinatum to the yield of Setaria sphacelata. East African Agricultural. and Forestry Journal. Nairobi, 37(3):215-219.

TIHARUHONDI, F. e R.S. MUSANGI. 1973. Application of nitrogen irrigation to pasture to enhance cattle production during the dry season in Uganda. East African Agricultural. and Forestry Journal. Nairobi, $38(4): 383-393$.

WALTHALL, J.C. e R.A. Mc KENZIE. 1976. Osteodytrophia fibrosa in horse at pasture in Queensland field and laboratory observations. Australian Veterinary Journal. Melbourne, $\underline{52}: 11-16$.

WARD, G.; L.H. HARBERS e J.J. BLAHA. 1979. Calcium - containing crystals in alfalfa: their fate in cattle. Journal Dairy. Science. Baltimore, $\underline{62: 715 .}$

WATTS, P.S. 1959. Effects of oxalic acid ingestion by sheep. 11. Large doses to sheep on differents diets. Journal. Agricultural Science.

WERner, J.C. 1984. Adubação de pastagens. Nova Odessa, SP., Instituto de Zootecnia (Boletim Técnico, 18). 49p. 
WIJK, A.J.P. van. 1976. Herbage yield and quality relationships of the three varieties of Setaria sphacelata (Schumach) Stapf and Hubbard. Metherlands Journal Agricultural Science, Wageningen, 24: 147-54.

ZAGATTO, E.A.G.; A.0. JACINTO; B.F. KRUG; H. BERGAMIN FILHO; L.C.R. PESSENDA; J. MORTATTI e M.F. GINE. 1981. Manual de anālises de plantas e ăguas empregando sistemas de injeção em fluxo. CENTRO dE ENERGIA nUCLEAR NA AgRICULTURA. Piracicaba-SP. $45 p$. 
$A \cdot P \hat{E} N D I C E$ 
Tabela 1 Produção de matéria seca a $70^{\circ} \mathrm{C}$ da parte aerea do capim setaria (g/vaso) em função dos'níveis de $\mathrm{N}$ e K

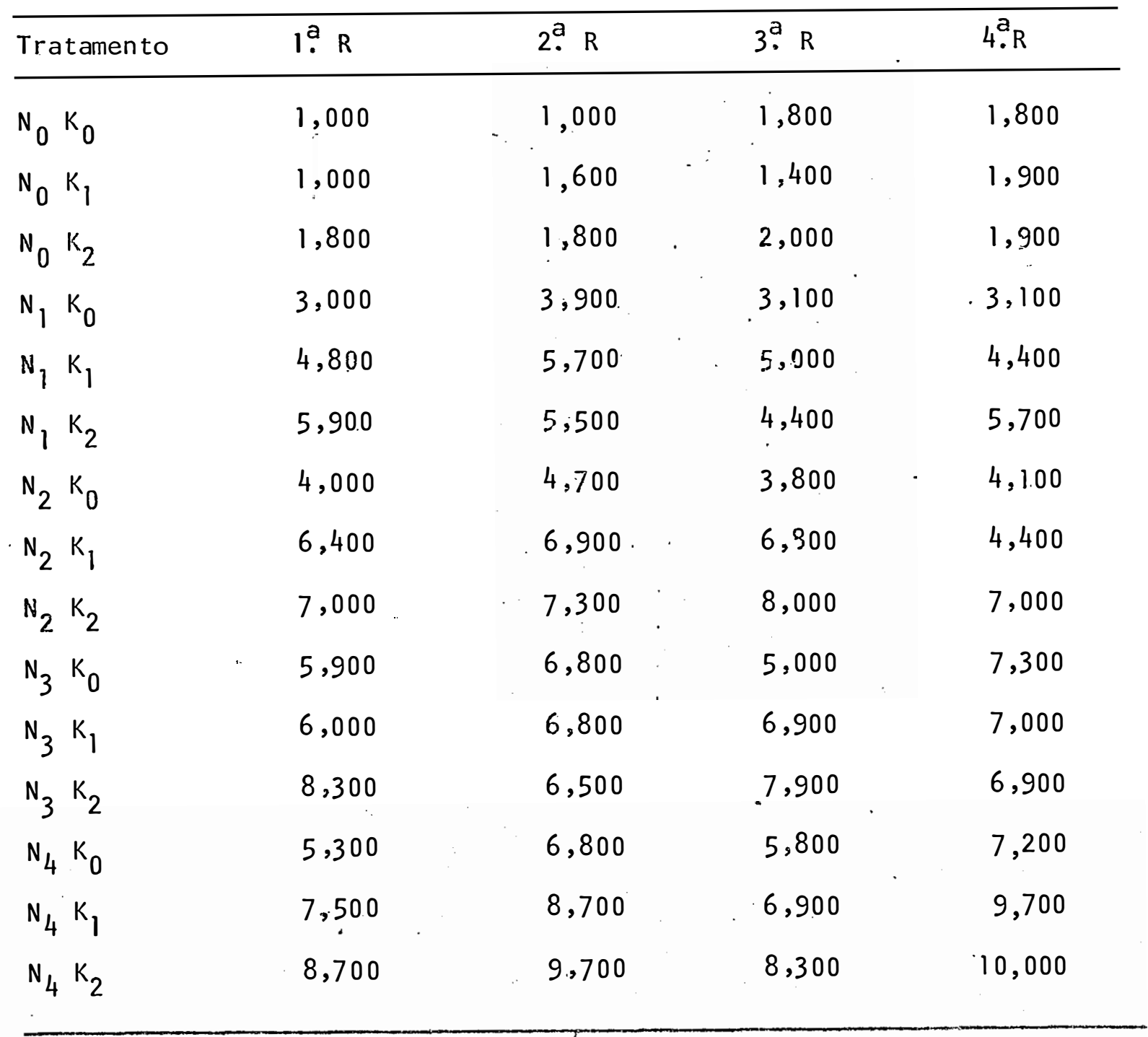


Tabela 2 - Concentração de Ácido 0xálico em \% na matēria seca $\left(70^{\circ} \mathrm{C}\right)$ da parte aérea do capin setaria em função dos niveis de $N$ e K

\begin{tabular}{|c|c|c|c|c|}
\hline Tratamentos & $I^{a} \mathrm{R}$ & 2. $R$ & $3{ }^{a} \cdot R$ & 4. $R$ \\
\hline$N_{0} \cdot K_{0}$ & 4,25 & 4,25 & 5,89 & 3,89 \\
\hline $\mathrm{N}_{0} \mathrm{~K}_{1}$ & 3,97 & 5,48 & 5,31 & 5,66 \\
\hline $\mathrm{N}_{0} \quad \mathrm{~K}_{2}$ & 5,84 & 6,28 & 5,49 & 5,96 \\
\hline $\mathrm{N}_{1} \mathrm{~K}_{0}$ & 4,25 & 3,81 & 3,89 & 4,78 \\
\hline$N_{1} K_{1}$ & 4,70 & 4,60 & 4,60 & 4,96 \\
\hline$N_{1} K_{2}$ & 5,31 & 5,66 & 6,20 & 5,84 \\
\hline $\mathrm{N}_{2} \mathrm{~K}_{0}$ & 4,78 & 4,60 & 4,60 & 5,04 \\
\hline$N_{2} K_{1}$ & 4,70 & 4,43 & 3,81 & 5,13 \\
\hline $\mathrm{N}_{2} \mathrm{~K}_{2}$ & 5,13 & 4,96 & 4,60 & $.5,58$ \\
\hline $\mathrm{N}_{3} \mathrm{~K}_{0}$ & 4,60 & 4,60 & 4,43 & 4,60 \\
\hline$N_{3} K_{1}$ & 4,25 & 5,13 & 4,43 & 4,60 \\
\hline $\mathrm{N}_{3} \mathrm{~K}_{2}$ & 4,43 & 5,40 & 6,73 & 6,80 \\
\hline $\mathrm{N}_{4} \mathrm{~K}_{0}$ & 5,66 & 4,16 & 4,96 & 5,31 \\
\hline $\mathrm{N}_{4} \mathrm{~K}_{1}$ & 5,58 & 5,31 & 5,49 & 5,40 \\
\hline $\mathrm{N}_{4} \mathrm{~K}_{2}$ & 5,13 & 4,69 & 4,60 & 5,13 \\
\hline
\end{tabular}


Tabela 3 - Concentração de Nitrogênio em \% na matéria seca da parte aérea do capim șetaria em função dos niveis de $\mathrm{N}$ e K

\begin{tabular}{|c|c|c|c|c|}
\hline Tratamentos & $1 \stackrel{a}{R}$ & $2^{a} \cdot R$ & $3 . \mathrm{a} \cdot \mathrm{R}$ & $4^{a} \cdot \mathrm{R}$ \\
\hline $\begin{array}{ll}N_{0} & K_{0}\end{array}$ & 0,64 & 0,75 & $0,86^{\circ}$ & 0,84 \\
\hline $\begin{array}{ll}N_{0} & K_{1}\end{array}$ & 0,75 & 0,79 & 0,62 & 0,73 \\
\hline $\begin{array}{ll}\mathrm{N}_{0} & \mathrm{~K}_{2}\end{array}$ & 0,59 & 0,59 & 0,62 & 0,62 \\
\hline $\begin{array}{ll}N_{1} & K_{0}\end{array}$ & $1,0.5$ & 0,90 & 0,97 & 1,05 \\
\hline $\begin{array}{ll}N_{1} & K_{1}\end{array}$ & 0,55 & 0,70 & 0,62 & 0,74 \\
\hline $\begin{array}{lll}N_{1} & K_{2}\end{array}$ & 1,10 & 1,32 & 1,32 & 1,30 \\
\hline $\mathrm{N}_{2} \quad \mathrm{~K}_{0}$ & 2,05 & 1,90 & 1,32 & 1,71 \\
\hline $\mathrm{N}_{2} \quad \mathrm{~K}_{1}$ & 1,72 & 1,64 & 1,57 & 1,46 \\
\hline $\mathrm{N}_{2} \quad \mathrm{~K}_{2}$ & 1,93 & 1,93 & 1,41 & 1,30 \\
\hline $\mathrm{N}_{3} \quad \mathrm{~K}_{0}$ & 2,12 & 2,09 & 2,27 & 2,16 \\
\hline $\mathrm{N}_{3} \quad \mathrm{~K}_{1}$ & 1,75 & 1,46 & 1,34 & 1,98 \\
\hline $\mathrm{N}_{3} \quad \mathrm{~K}_{2}$ & 1,91 & 2,09 & 2,89 & 2,18 \\
\hline $\mathrm{N}_{4} \quad \mathrm{~K}_{0}$ & 3,18 & 3,10 & 3,05 & 3,09 \\
\hline $\begin{array}{lll}N_{4} & K_{1}\end{array}$ & 2,46 & 2,66 & 2,55 & 2,55 \\
\hline $\begin{array}{ll}N_{4} & K_{2}\end{array}$ & 1,94 & 1,91 & 2,01 & 1,99 \\
\hline
\end{tabular}


Tabela 4 - Concentração de Potāssio em \% na matéria seca da parte aérea do capim setaria em função dos níveis de $\mathrm{N}$ e $\mathrm{K}$

\begin{tabular}{|c|c|c|c|c|c|c|}
\hline Tratamentos & & $1 \cdot \mathrm{R}$ & & 2. $\mathrm{R}$ & 3. $\mathrm{R}$ & $4^{a} \cdot R$ \\
\hline $\mathrm{N}_{0} \cdot \mathrm{K}_{0}$ & & 0,72 & & 0,62 & 0,94 & 0,74 \\
\hline $\mathrm{N}_{0} \mathrm{~K}_{1}$ & & 1,44 & & 1,36 & 1,52 & 1,28 \\
\hline $\mathrm{N}_{0} \mathrm{~K}_{2}$ & $\cdot$ & 2,80 & & 3,12 & 2,72 & 2,72 \\
\hline $\mathrm{N}_{1} \mathrm{~K}_{0}$ & & 0,36 & & 0,36 & 0,48 & 0,30 \\
\hline$N_{1} K_{1}$ & & 1,04 & & 0,88 & 0,80 & 1,04 \\
\hline$N_{1} K_{2}$ & & 4,23 & . & 4,52 & 4,58 & 4,44 \\
\hline $\mathrm{N}_{2} \mathrm{~K}_{0}$ & & 0,90 & & 1,03 & 0,86 & 0,60 . \\
\hline $\mathrm{N}_{2} \mathrm{~K}_{1}$ & $\cdot$ & 2,72 & & 2,84 & 2,37 & 2,22 \\
\hline $\mathrm{N}_{2} \mathrm{~K}_{2}$ & & 4,20 & & 4,24 & 4,12 & 4,44 \\
\hline$N_{3}, K_{0}$ & & 0,80 & & 0,92 & 0,36 & 0,54 \\
\hline $\mathrm{N}_{3} \mathrm{~K}_{1}$ & & 2,20 & . & 2,20 & 2,05 & 1,96 \\
\hline $\mathrm{N}_{3} \mathrm{~K}_{2}$ & & 3,44 & & 3,68 & 3,76 & 3,56 \\
\hline $\mathrm{N}_{4} \mathrm{~K}_{0}$ & . & 0,32 & & 0,32 & 0,28 & 0,43 \\
\hline $\mathrm{N}_{4} \mathrm{~K}_{1}$ & & 2,36 & & 2,04 & 2,20 & 2,55 \\
\hline $\mathrm{N}_{4} \mathrm{~K}_{2}$ & & 2,34 & 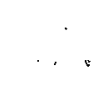 & 3,12 & 3,52 & 3,30 \\
\hline
\end{tabular}


Tabela 5 - Concentração de Cālcio em \% na matéria seca da parte aērea do capim setaria em função dos niveis de $\mathrm{N}$ e K

\begin{tabular}{lllll}
\hline Tratamentos & $1 . \mathrm{R}$ & $2{ }^{\mathrm{a}} \mathrm{R}$ & $3{ }^{\mathrm{a}} \mathrm{R}$ & $4^{\mathrm{a}} \mathrm{R}$ \\
\hline $\mathrm{N}_{0} \mathrm{~K}_{0}$ & 0,36 & 0,36 & 0,46 & 0,43 \\
$\mathrm{~N}_{0} \mathrm{~K}_{1}$ & 0,47 & 0,45 & 0,35 & 0,43 \\
$\mathrm{~N}_{0} \mathrm{~K}_{2}$ & 0,45 & 0,43 & 0,47 & 0,37 \\
$\mathrm{~N}_{1} \mathrm{~K}_{0}$ & 0,43 & 0,37 & 0,45 & 0,49 \\
$\mathrm{~N}_{1} \mathrm{~K}_{1}$ & 0,17 & 0,20 & 0,17 & 0,27 \\
$\mathrm{~N}_{1} \mathrm{~K}_{2}$ & 0,34 & 0,33 & 0,34 & 0,33 \\
$\mathrm{~N}_{2} \mathrm{~K}_{0}$ & 0,37 & 0,38 & 0,38 & 0,32 \\
$\mathrm{~N}_{2} \mathrm{~K}_{1}$ & 0,46 & 0,45 & 0,45 & 0,46 \\
$\mathrm{~N}_{2} \mathrm{~K}_{2}$ & 0,30 & 0,35 & 0,31 & 0,33 \\
$\mathrm{~N}_{3} \mathrm{~K}_{0}$ & 0,47 & 0,46 & 0,45 & 0,43 \\
$\mathrm{~N}_{3} \mathrm{~K}_{1}$ & 0,43 & 0,40 & 0,38 & 0,39 \\
$\mathrm{~N}_{3} \mathrm{~K}_{2}$ & 0,43 & 0,37 & 0,38 & $0,34$. \\
$\mathrm{N}_{4} \mathrm{~K}_{0}$ & 0,47 & 0,47 & 0,40 & 0,43 \\
$\mathrm{~N}_{4} \mathrm{~K}_{1}$ & 0,40 & 0,38 & 0,38 & 0,43 \\
$\mathrm{~N}_{4} \mathrm{~K}_{2}$ & 0,34 & 0,34 & 0,30 & 0,36 \\
\hline & & & 0 & \\
\hline
\end{tabular}


Tabela 6 : - Concentração de Magnésio em \% na matéria seca da parte aërea do capim setaria em função dos níveís de $\mathrm{N}$ e $\mathrm{K}$

\begin{tabular}{lllll}
\hline Tratamentos & $1^{a} \mathrm{R}$ & $2^{\mathrm{a}} \mathrm{R}$ & $3^{\mathrm{a}} \mathrm{R}$ & 4. $\mathrm{R}$ \\
\hline $\mathrm{N}_{0} \mathrm{~K}_{0}$ & 0,31 & 0,36 & 0,36 & 0,40 \\
$\mathrm{~N}_{0} \mathrm{~K}_{1}$ & 0,28 & 0,28 & 0,24 & 0,29 \\
$\mathrm{~N}_{0} \mathrm{~K}_{2}$ & 0,27 & 0,28 & 0,27 & 0,26 \\
$\mathrm{~N}_{1} \mathrm{~K}_{0}$ & 0,52 & 0,54 & 0,44 & 0,45 \\
$\mathrm{~N}_{1} \mathrm{~K}_{1}$ & 0,18 & 0,18 & 0,21 & 0,28 \\
$\mathrm{~N}_{1} \mathrm{~K}_{2}$ & 0,31 & 0,28 & 0,29 & 0,33 \\
$\mathrm{~N}_{2} \mathrm{~K}_{0}$ & 0,45 & 0,43 & 0,40 & 0,43 \\
$\mathrm{~N}_{2} \mathrm{~K}_{1}$ & 0,46 & 0,36 & 0,40 & 0,40 \\
$\mathrm{~N}_{2} \mathrm{~K}_{2}$ & 0,31 & 0,31 & 0,27 & 0,29 \\
$\mathrm{~N}_{3} \mathrm{~K}_{0}$ & 0,47 & 0,48 & 0,56 & 0,56 \\
$\mathrm{~N}_{3} \mathrm{~K}_{1}$ & 0,37 & 0,36 & 0,36 & 0,30 \\
$\mathrm{~N}_{3} \mathrm{~K}_{2}$ & 0,32 & 0,24 & 0,31 & 0,29 \\
$\mathrm{~N}_{4} \mathrm{~K}_{0}$ & 0,70 & 0,61 & 0,52 & 0,53 \\
$\mathrm{~N}_{4} \mathrm{~K}_{1}$ & 0,36 & 0,37 & 0,35 & 0,35 \\
$\mathrm{~N}_{4} \mathrm{~K}_{2}$ & 0,28 & 0,33 & 0,29 & 0,32 \\
\hline & & & & \\
\hline
\end{tabular}

